4 norden 



\section{Nordic Seabird Colony Databases}

Results of a Nordic project on seabird breeding colonies in Faroes, Greenland, Iceland, Jan Mayen and Svalbard

Vidar Bakken, David Boertmann, Anders Mosbech, Bergur Olsen, Aevar Petersen, Hallvard Strøm, Harvey Goodwin 


\section{Nordic Seabird Colony Databases}

Results of a Nordic project on seabird breeding colonies in Faroes, Greenland, Iceland, Jan Mayen and Svalbard

TemaNord 2006:512

(c) Nordic Council of Ministers, Copenhagen 2006

ISBN 92-893-1301-3

Print: Rosendahls Bogtrykkeri AS, Esbjerg 2006

Cover photo: Common Guillemots Uria aalge on the southern tip of Bear Island (Bjørnøya), Svalbard. Photo: Hallvard Strøm, July 2002.

Copies: 450

Printed on environmentally friendly paper

This publication can be ordered on www.norden.org/order. Other Nordic publications are available at www.norden.org/publications

Printed in Denmark

Nordic Council of Ministers

Store Strandstræde 18

DK-1255 Copenhagen K

Phone (+45) 33960200

Fax (+45) 33960202

www.norden.org

www.norden.org

\section{Nordic Council}

Store Strandstræde 18

DK-1255 Copenhagen K

Phone (+45) 33960400

Fax (+45) 33111870

\section{Nordic Environmental Co-operation}

The Nordic Environmental Action Plan 2005-2008 forms the framework for the Nordic countries' environmental co-operation both within the Nordic region and in relation to the adjacent areas, the Arctic, the EU and other international forums. The programme aims for results that will consolidate the position of the Nordic region as the leader in the environmental field. One of the overall goals is to create a healthier living environment for the Nordic people.

\section{Nordic co-operation}

Nordic co-operation, one of the oldest and most wide-ranging regional partnerships in the world, involves Denmark, Finland, Iceland, Norway, Sweden, the Faroe Islands, Greenland and Åland. Cooperation reinforces the sense of Nordic community while respecting national differences and similarities, makes it possible to uphold Nordic interests in the world at large and promotes positive relations between neighbouring peoples.

Co-operation was formalised in 1952 when the Nordic Council was set up as a forum for parliamentarians and governments. The Helsinki Treaty of 1962 has formed the framework for Nordic partnership ever since. The Nordic Council of Ministers was set up in 1971 as the formal forum for co-operation between the governments of the Nordic countries and the political leadership of the autonomous areas, i.e. the Faroe Islands, Greenland and Åland. 


\section{Contents}

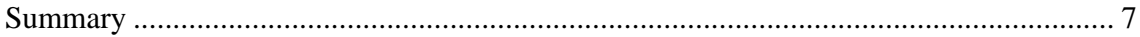

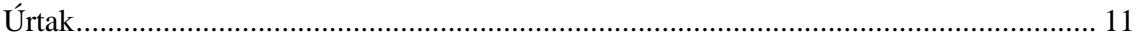

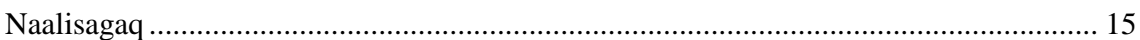

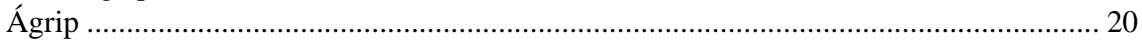

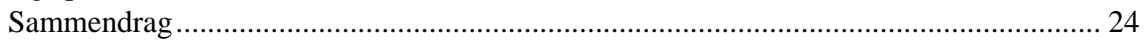

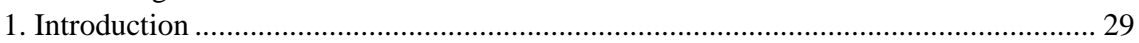

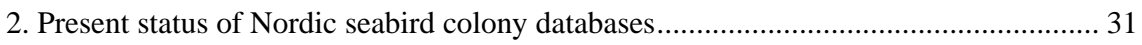

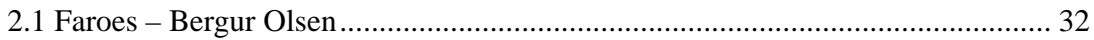

2.2 Greenland - David Boertmann and Anders Mosbech ......................................... 36

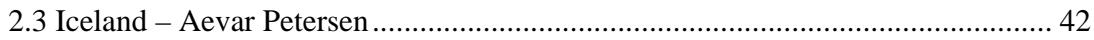

2.4 Jan Mayen and Svalbard - Hallvard Strøm ....................................................... 48

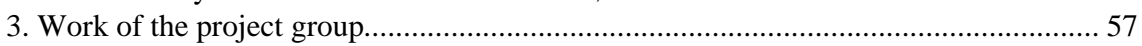

4. Description of the database system - Vidar Bakken and Harvey Goodwin................... 61

5. The use of seabird colony databases - David Boertmann and Anders Mosbech .......... 69

6. Template for Arctic seabird colony databases - Hallvard Strøm and Aevar Petersen .. 73

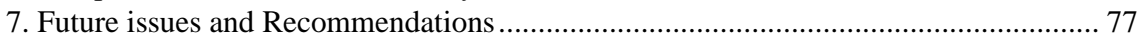

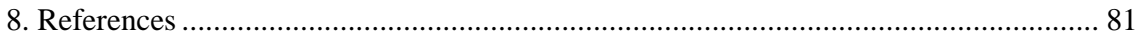

Appendix - User's Manual - Vidar Bakken and Harvey Goodwin ................................... 87 



\section{Summary}

The present report deals with harmonized databases for seabird colonies in the Nordic countries. The countries fringing the North-Atlantic seaboard have large and globally important seabird resources. The number of species, which regularly breed in these countries, are combined 30, the number of colony sites could be around 10 thousand (often more than one species nesting at same site), and the numbers of breeding pairs estimated nearly 50 million (of which Little Auk, especially in Greenland, far outnumber any other species with around 38 million pairs). In recognition of these facts, to fulfil the recommendations in the Arctic Nordic Action Plan from 1999 and obligations to circumpolar Arctic cooperation, the Nordic Council of Ministers provided funds for the harmonization of seabird colony databases in the Nordic countries.

The project group:

From December 2002 a Nordic project group, with participants from Greenland, Faroes, Iceland, and Norway (for Jan Mayen and Svalbard), worked on the issue of harmonized seabird colony databases. The purposes as sat out in the funding application, were:

- Establish a harmonized database of seabird colonies for Faroes, Greenland, Iceland, Jan Mayen, and Svalbard

- Collect available outstanding data and refine the present databases to make them more applicable

- Explore the most appropriate computer software for holding databases and for preparing products, such as graphic presentations

- Explore how to assemble a joint database and define common rules for its use

- Explore if the database format can be expanded to other Arctic regions

- Produce a report on the results and main findings of the project

Status reports:

During the only formal meeting of the project group, each country gave a short overview of the status of their seabird colony databases, summarized below:

Faroes: Number of breeding species: 20; Number of colonies: c. 1600; Number of breeding pairs: c. 1.7 million. No database had been compiled prior to the present project work. Main monitoring programs involve Common Guillemots, Kittiwakes and Gannets.

Greenland: Number of breeding species: 21; Number of colonies: c. 3700; Number of breeding pairs: 38.05 million. A database was available 
prior to the present work but needed adjustment and modernization in software. Monitoring programs have been initiated or proposed for Brünnich's Guillemots, Common Eiders and Arctic Terns.

Iceland: Number of breeding species: 23; Number of colonies: c. 4500; Number of breeding pairs: perhaps 7,5 million. No official database had been compiled prior to the present work, but skeleton database (in excel) was available for certain species. Monitoring is carried out for the entire population of two species (Gannet, Cormorant). For ten species selected colonies are monitored, not fully representing the Icelandic breeding population, while no programs exist for ten species.

Svalbard: Number of breeding species: 18; Number of colonies: min. 1536; Number of breeding pairs: 2,8-3,1 million. The colony database for Svalbard needed upgrading, in terms of software and harmonization of structure. By 2004 seven species (Northern Fulmar, Common Eider, Glaucous Gull, Black-legged Kittiwake, Common Guillemot, Brünnich’s Guillemot and Little Auk) are included in the Svalbard monitoring programme.

Jan Mayen: Number of breeding species: 15; Number of colonies: min. 92; Number of breeding pairs: c. 300 thousand. No database had been compiled prior to the present work for Jan Mayen. No monitoring of seabirds is undertaken on Jan Mayen.

Harmonization of databases:

The colony database consists of three main tables: Colony description, colony survey and study plot. Tables containing references, observers and photo documentation are linked to the three main tables.

The Colony description tables include, besides colony location information, details of conservation status, ownership, and presence of alien predators, historical records, references, and how well the colony lends itself to catching birds for ringing or other research. The Colony survey tables contains details of individual censuses, such as species, date, observer, bird numbers, census accuracy, what unit is counted, and references. The Study plot tables, which are designed for monitoring, include a combination of the details as contained in both the above tables. The Reference tables include details of bibliographic or archival information. The Observers tables contain references as to the observers responsible for the colony information. The Photo documentation tables contain references to any photographic material, which accompanies census data.

The program is available on the internet through the link: ftp://ftp.npolar.no/Out/NordicDatabase/. This can be downloaded free of charge. The manual to the program is found in the Appendix to the report. For further information on individual national databases please contact the respective country representative, see list of authors. The Greenland database is accessible to the public at http://www.dmu.dk/Grønland/Olie+og+Miljø/Havfuglekolonier/. 
The use of seabird colony databases:

The purpose of seabird colony databases is to keep organized, updated information, primarily on the location, composition and size of seabird colonies. These data can be made readily available for different purposes; research, outreach, conservation, and management. As such these are important management tools, which should be integral parts of conservation and sustainable use policies or agendas. As such the data are useful for local planning, environmental impact assessments, monitoring, different kinds of research, and to base on educational materials. Harmonized databases have a wider application in that the data can be combined for common analyses over larger area than for any individual country.

Template for Arctic seabird colony databases:

The idea to establish a harmonized database format for seabird colonies in Faroes, Greenland, Iceland, Jan Mayen, and Svalbard is partly a product of, and has strong links to, the work of the Circumpolar Seabird Group (CBird), an expert group under the program for Conservation of Arctic Flora and Fauna (CAFF), one of the permanent working groups of the Arctic Council. As was the case for some of the Nordic countries, several of the Arctic countries already have well established databases for both scientific and management purposes. The idea for a circumpolar seabird database format was discussed at the meeting of the CBird group in Aberdeen, Scotland, in March 2005. The general idea was very well received, as both Canada and Alaska (for USA) have databases which need updating and the Nordic Seabird Colony Databases format will be a very good solution. It appears that the middle part of Russia is not covered by neither of the two current Russian databases (for western Russia and for eastern Russia), but this needs to be further explored.

Future issues:

The project group recognized that the issue of harmonized seabird colony databases was not completed with the end of the present project. A number of future issues were identified as follows:

- Each country continues to maintain their seabird colony database, update, correct mistakes, add accessory details which may be lacking on individual colonies, e.g. habitat type, spread of colony, conservation status of the colony land, land ownership, etc.

- A harmonized seabird colony database makes it possible to undertake different common analyses on the data presently available in the participating countries over larger regions than hitherto possible, but many different kinds of analyses are feasible, such as:

o N-Atlantic Seabird Colony Catalogue

o Scientific assessments of individual species, or group of species, including details of the colonies, colony size, trend data, etc. 
- An overview of the conservation status of how well seabird colonies are protected in the different countries.

- An analysis of the habitats and under which circumstances colonies are situated, both between and within species.

- A manual of methodologies and conversion factors used in censusing different kinds of seabirds.

- Develop a web-based portal for assessing of a common Nordic Seabird Colony Database, for inputting data, making common analyses, use in management questions, etc.

- A development of linking to the present database program modules which would hold data on breeding success, food, survival, etc. and allows different sophisticated analyses.

- Intensify fieldwork to census unexplored regions, localize unregistered colonies and census these for size.

- Contribute to a general scientific and authoritative work on Atlantic seabirds. 


\section{Úrtak}

Hendan frágreiðing viðger eina verkætlan um felags dátugrunnar, sum vísa hvar sjófuglur byggir í Norðurlondum. Londini í Norðurhøvum hava nógvan sjófugl, sum hevur altjóða týdning. Talið á sløgum, sum regluliga eigur í hesum londum, er tilsamans 30, talið á bølum man vera um 10 túsund (ofta eigur meira enn eitt slag á sama staði), og talið á pørum verður mett at vera um 50 milliónir (fulkubbastovnurin, serliga í Grønlandi, er nógv tann størsti við eini 38 milliónum pørum). Norðurlandaráðið hevur stuðlað hesi verkætlan at gera dátugrunnar eftir sama leisti fyri øll norðurlond. Hetta er gjørt sambært tilmælini í Arctic Nordic Action Plan 2000-2004.

Verkætlanarbólkurin:

Síðani desember 2002 hevur ein norðurlendskur verkætlanarbólkur við luttakarum úr Grønlandi, Føroyum, Íslandi og Noreg (fyri Jan Mayen og Svalbarð) arbeitt við at gera ein felags leist til dátugrunnar yvir sjófuglabøli. Málini, sum vórðu sett fram í umsóknini, vóru hesi:

- Gera ein felags dátugrunn yvir sjófuglabøli í Føroyum, Grønlandi, Íslandi, Jan Mayen og Svalbarð

- Savna verandi dáta og betra verandi dátugrunnar.

- Kanna tey frægastu telduforritini til dátugrunnar og til at vísa úrslitini á korti.

- Kanna hvussu ein ger ein felags dátugrunn og felags reglur fyri nýtslu av grunninum.

- Kanna um leisturin til forritið kann verða nýttur í øðrum arktiskum londum.

- Skriva eina frágreiðing um úrslitini og høvuðsmálini, ið funnin vórðu fram til í verkætlanini.

Støðufrágreiðing:

Á tí einasta formliga fundinum, sum bólkurin hevur havt, gav hvørt landið eitt stutt yvirlit yvir støðuna viðvíkjandi teirra dátugrunni um sjófuglabøli. Niðan fyri er tikið samanum.

Føroyar: Talið á fuglasløgum, sum eiga: 20; Talið á bølum: o.u. 1600; Talið á pørum, sum eiga: o.u. 1,7 milliónir. Ongin dátagrunnur var, tá ið hendan verkætlanin byrjaði. Høvuðsdentur hevur verið lagdur á at hava eftirlit við lomviga-, ritu- og súlustovnunum.

Grønland: Talið á fuglasløgum, sum eiga: 21; Talið á bølum: o.u. 3700; Talið á pørum, sum eiga: 38,05 milliónir. Ein dátugrunnur var, tá ið hendan verkætlanin byrjaði, men tørvur var á broytingum og nýggjum 
forritum. Eftirlit er við, ella tað verður mælt til at hava eftirlit við, íslandslomviga, æðu og ternu.

Ísland: Talið á fuglasløgum, sum eiga: 23; Talið á bølum: o.u. 7000; Talið á pørum, sum eiga: kanska 7,5 milliónir. Ongin rættiligur dátugrunnur var áðrenn hetta arbeiðið byrjaði, men summi fuglasløg vóru skrivað inn í Excel. Eftirlit er við øllum stovninum av tveimum sløgum (súlu og hiplingi). Fyri 10 sløg verður eftirlit hildið í útvaldum bølum, sum ikki til fulnar umboða tann íslendska stovnin. Onki eftirlit er við 10 sløgum.

Svalbarð: Talið á fuglasløgum, sum eiga: 18; Talið á bølum: í minsta lagi 1536; Talið á pørum, sum eiga: 2,8-3,1 milliónir. Dátugrunnurin fyri Svalbarð trongdi til at verða dagførdur, bæði forrit og bygnaður. Í 2004 vóru 7 fuglasløg (havhestur, æða, valmási, rita, lomvigi, íslandslomvigi og fulkubbi) við í eftirlitsverkætlanini fyri Svalbarð.

Jan Mayen: Talið á fuglasløgum, sum eiga: 15; Talið á bølum: í minsta lagi 92; Talið á pørum, sum eiga: o.u. 300 túsund. Ongin dátugrunnur var fyri Jan Mayen áðrenn hetta arbeiðið, og onki eftirlit er við sjófuglinum.

Harmonisering av dátugrunnunum:

Dátugrunnurin hevur tríggjar høvuðstalvur: Lýsing av bølinum, teljing av fuglinum í bølinum og lýsing av smærri kanningarøkjum í bølinum, har neyvar kanningar fara fram. Talvur við heimildum, eygleiðarum og myndum eru knýttar at teimum trimum høvuðstalvunum.

Talvan við lýsing av bølunum inniheldur, umframt staðseting, eisini upplýsingar um vernd av økinum, ognarskap, rovdýr, søgulig tøl, heimildir og hvussu væl bølið hóskar til at ringmerkja fugl í og at gera aðrar kanningar. Talvan yvir teljingar inniheldur nágreiniligar lýsingar av einstøku teljingunum so sum fuglaslag, dato, eygleiðara, tal av fugli, neyvleika í teljingunum, hvør eind er nýtt og heimildir. Talvan yvir kanningarøkini inniheldur neyvar teljingar í hesum økjum umframt upplýsingar úr báðum teimum fyrru talvunum. Heimildartalvan inniheldur bæði almannakunngjørdar og ikki almannakunngjørdar heimildir. Eygleiðaratalvan inniheldur tilvísingar til eygleiðarar, sum hava ábyrgd av upplýsingunum um bølið. Myndatalvan inniheldur tilvísingar til myndatilfar, sum hoyrir til einstøku teljingarnar.

Forritið sæst á internetinum á slóðini: ftp://ftp.npolar.no/Out/NordicDatabase/. Tað kann verða tikið niður ókeypis. Vegleiðingin til forritið stendur í ískoytinum til hesa frágreiðing. Nærri upplýsingar um einstøku dátugrunnarnar fáast hjá tí, sum hevur ábyrgdina fyri viðkomandi land, sí høvundalistan. Grønlendski dátugrunnurin er opin fyri øllum á slóðini:

http://www.dmu.dk/Grønland/Olie+og+Miljø/Havfuglekolonier/. 
Nýtsla av sjófugla dátugrunnum:

Endamálið við dátugrunnum yvir sjófuglabøli er, at hava skipaðar dagførdar upplýsingar, serstakliga um hvar bølini eru, og hvussu stór tey eru. Hesir upplýsingar kunnu t.d. lættliga nýtast til kanningar, upplýsing, vernd og umsiting. Dátugrunnarnir eru sostatt eitt týðandi amboð í umsitingini, tá ið støða verður tikin til varðveitslu og burðardygga nýtslu av náttúruni. Úrslitini kunnu eisini nýtast sum eftirlit, til at máta umhvørvisárin og sum grundarlag til undirvísingartilfar. Samskipaðir dátugrunnar millum lond hava eitt enn størri virði, av tí at upplýsingar kunnu samskipast til felags viðgerð yvir størri øki enn nakað einstakt land.

Leistur til dátugrunn um arktisk sjófuglabøli:

Hugskotið at gera dátugrunnarnar eftir sama leisti í Føroyum, Grønlandi, Íslandi, Jan Mayen og Svalbarð er partvís eitt úrslit av og er tengt at arbeiðinum í Circumpolar Seabird Group (CBird). Hetta er ein bólkur av serfrøðingum undir stevnuskránni Conservation of Arctic Flora and Fauna (CAFF), ein av teimum føstu arbeiðsbólkunum í tí arktiska ráðnum. Á sama hátt, sum onkur av teimum norðurlendsku londunum, so hava fleiri av teimum arktisku londunum longu dátugrunnar til bæði vísindalig og umsitingarlig endamál. Hugskotið, til ein felags leist fyri sjófugladátugrunnar í øllum teimum arktisku londunum, varð umrøtt á CBird fundinum í Aberdeen, Skotlandi, í mars 2005. Hugskotið fekk góða undirtøku, tí bæði Kanada og Alaska (fyri USA) hava dátugrunnar, sum skulu dagførast, og leisturin á tí norrøna dátugrunninum er ein góð loysn. Tað tikist sum tann mittasti parturin av Russlandi ikki er við í nøkrum at teimum tveimum russisku dátugrunnunum (fyri vestur Russland og fyri eystur Russland), men hetta má kannast nærri.

Framtíðar mál:

Verkætlanarbólkurin ásannaði, at málið við sjófugladátugrunnum eftir sama leisti, var ikki rokkið til fulnar við hesum arbeiði. Fleiri onnur mál liggja fyri framman:

- Hvørt land heldur fram at røkja teirra dátugrunn yvir sjófuglabøli. Grunnurin má dagførast, mistøk rættast og smálutir, sum vanta fyri einstøku bølini, mugu skrivast inn, t.d. lendisviðurskifti, útbreiðsla av bølinum, hvussu lendið verður vart og hvør eigur tað o.s.fr.

- Við einum felags sjófugladátugrunni ber til at gera ymsar felags greiningar av upplýsingum yvir størri øki, enn tað hevur verið gjørligt higartil, so sum:

o Ein skrá yvir sjófuglabøli í Norðurhøvum.

o Vísindaligar metingar av einstøkum fuglasløgum ella bólkum við nágreiniligum lýsingum av bølunum, stødd av bølunum, broytingum o.s.fr.

- Eitt yvirlit yvir hvussu væl sjófuglabøli eru vard í ymiskum londum. 
- Ein greining av lendinum og teimum umstøðum har bølini eru, bæði ímillum ymisk fuglasløg og innan somu sløg.

- Ein handbók um hvussu ein best telur ymiskan sjófugl og hvørjar umrokningar verða nýttar.

- Gera ein portal á alnótini, har ein kann koma inn á norrøna dátugrunnin um sjófuglabøli og skriva nýggjar upplýsingar inn, gera felags greiningar og svara spurningum um umhvørvismál o.s.fr.

- Gera tað møguligt at binda onnur modul uppí, sum kunnu innihalda dáta um hvussu stórur partur av pisunum koma undan, føði, yvirlivilsi o.s.fr. og soleiðis gera ymsar framúrskarandi greiningar.

- Økja um útiarbeiðið til at telja bøli, ið ikki eru tald áður og til at finna bøli, ið ikki eru skrásett og telja hvussu stór hesi eru.

- Geva upplýsingar til eitt vísindaligt og viðurkent arbeiði um sjófugl í Atlantshavi. 


\section{Naalisagaq}

Nalunaarusiaq una tassaavoq Nunani Avannarlerni timmissat imarmiusut inissisimaffii pillugit ataatsimoortumik qarasaasiatigut nalunaarsuinermut tunngasoq. Nunat Atlantikup avannaata imartaanut atasut amerlasuunik nunarsuullu sinneranut pingaaruteqartunik imarmiusunik timmiaqarfiupput. Nunani taakkunani timmissat piaqqiortartut assigiinngitsut katillutik 30-it missaaniipput, piaqqiorfigisartagaallu neriniarfigisartagaallu piffiit tuusintit qulit missaanni amerlassuseqarlutik (tamatumanilu timmissat assigiinngitsut piffinni aalajangersimasuni ataatsimoorlutik ulloqatigiissinnaasarput). Timmissat aappariit piaqqiortut 50 mio. missaani amerlassuseqarnissaat naatsorsuutigineqarpoq (annertunerpaamillu Kalaallit Nunaaniinnerusoq appaliarsuit immikkut amerlanerpaajullutik, timmissanit aappariinnit allanit amerlanerujussuullutik, tassa 38 mio. missaaniillutik). Pissutsit taama inneri paasillugit suliassiissutip Arctic Nordic Action Plan 2000-2004 - mik taaguuserneqarsimasup aalajangersagai piviusunngortinniarlugit aammalu Issittumi nunat akornani suleqatigiinnerup pisussaaffiliussai naammassiniarlugit, Nunani Avannarlerni Ministerit Siunnersuisoqatigiivisa timmissat imarmiut Nunani Avannarlerni inissisimaffiisa qarasaasiatigut ataatsimoortumik nalunaarsorneqarnissaat aningaasalersimavaat.

Suliarinnittussat: December 2002 aallarnerfigalugu suliarinnittussat nunanit ukuninngaannersut: Kalaallit Nunaat, Savalimmiut, Island kiisalu Norge (tamatumani Svalbard aamma Jan Mayen pineqarput) timmissat sumiiffiisa qarasaasiatigut nalunaarsorneqarnissaat suliaralugu aallartippaat. Suliassap aningaasalersornissaanut qinnuteqaammi makku siunertassatut pingaartinneqarput:

- Savalimmiuni, Kalaallit Nunaanni, Island-imi, Jan Mayen-imi Svalbard-imilu ataatsimoortumik qarasaasiatigoortumik timmissat katerisimaartarfiinik nalunaarsuinissaq

- Paasissutissanik pioreersunik paasissutissallu paasiuminarsarnerullugit tamanut atuaruminarsarlugit katersuinissaq

- Ataatsimoortumik paasisat katersornissaat avammullu saqqummiunnissaat siunertaralugu qarasaasiatigut atortussat naleqqunnerpaat nassaariniassalugit, tamatumanilu saqqummiinermi titartagalersornissaat isumagissallugu

- Ataatsimoortumik tamattalu pigisassatsinnik qarasaasiatigut paasissutissanik katersuinissaq misissussallugu atornissaanullu ilitsersuutissanik aalajangersaaneq isumaqatigiissusiussallugu

- Qarasaasiatigut paasissutissat aaqqissukkat qanoq ililluni issittup sinneranut siammartinneqarsinnaanersut misissussallugu 
- Paasisat inaarneri suliamilu paasisat pingaarnerit nalunaarusiussallugit

\section{Maannakkut killiffik:}

Pilersaarusiortut akornanni ataatsimeeqatigiittarsimanerni nunat peqataasut ataasiakkaarlutik nunaminni timmissanut imarmiunut tunngasunik ilisimasatik qarasaasiamiititatillu pillugit nalunaaruteqarput, imatullu naalisarlugit saqqummiunneqarsinnaapput:

Savalimmiut:Timmissat piaqqiortut amerlassusaat: 20; Piaqqiorfiisa amerlassusaat: 1.600; Aappariit piaqqiortut amerlassusaat: 1,7 mio. miss. Maannakkut qarasaasiatigut paasissutissanik katersuiniarneq sioqqullugu taamaaliortoqarsimanngilaq. Immikkut misissuiffigisat ukuupput: Appat, taateraat aamma timmiit.

Kalaallit Nunaat:Timmissat piaqqiortut amerlassusaat: 21; Piaqqiorfiisa amerlassusaat: 3.700 miss.; Aappariit piaqqiortut amerlassusaat: 38,05 mio. Massuma suliniutip aallartinneqarnera sioqqullugu qarasaasiatigut paasissutissanik katersuisoqareersimavoq qarasaasiatigulli najoqqutassat naleqqussartariaqarsimapput nutarterneqartariaqarlutillu. Immikkut appat, mitit aamma imeqqutaalat misissuiffigineqarlutik aallartinneqarsimmapput iml. misissuiffigineqarnissaat siunnersuutigineqarsimalluni.

Island: Timmissat piaqqiortut amerlassusaat: 23; Piaqqiorfiisa amerlassusaat: 7.000 miss; Aappariit piaqqiortut amerlassusaat: immaqa 7,5 mio. Maannakkut qarasaasiatigut paasissutissanik katersuiniarneq sioqqullugu pisortatigoortumik taamaaliortoqarsimanngilaq, taamaakkaluartorli Excel atorlugu paasissutissat tunngaviinik peqartoqarpoq. Timmissat aalajangersimasut marluk (timmik amma oqaatsoq) tamakkiisumik misissugarineqarput. Timmissat assigiinngitsut allat qulit eqqarsaatigalugit piaqqiorfii mississorneqarput, taamaaliornikkulli Island tamakkerlugu piaqqiorneri pineqarani, allallu timmissat assigiinngitsut qulit immikkut misissornissaannut pilersaaruteqartoqanngilaq.

Svalbard: Timmissat piaqqiortut amerlassusaat: 18; Piaqqiorfiisa amerlassusaat: minn. 1.536; Aappariit piaqqiortut amerlassusaat: 2,8 3,1 mio. Svalbard-imi qarasaasiatigut pigisat pitsanngorsartariaqarput, tamatumani software ataatsimoorussamillu suliarineqarnissaat eqqarsaatigalugit. 2004-mi timmissat arfineq marluk (qaqulluit, mitit, naajarujussuit, taateraat, appat assigiinngitsut appaliarsuillu) Svalbard-imi mississuinernut ilaatinneqarput.

Jan Mayen: Timmissat piaqqiortut amerlassusaat 15; Piaqqiorfiisa amerlassusaat: minn. 92; Aappariit piaqqiortut amerlassusaat: 300.000 miss. Maannakkut suliniut sioqqullugu Jan Mayen-imi qarasaasiatigut paasissutissanik katersuisoqarsimanngilaq. Jan Mayen-imi timmissanik imarsiortunik misissuisoqanngilaq. 
Qarasaasiatigut katersat ataatsimoortinnissaat:

Timmissat sumiiffiinik qarasaasiatigut katersat pingasunngorlugit agguataarneqarsinnaapput: Sumiiffiisa oqaluttuarineri, sumiiffiinik alaatsinaanneq kiisalu misissuinermi najoqqutarisat. Taakkunani tamani allanut innersuussinerit, nakkutilliisut paasisaat, kiisalu assilissat ilaatinneqarput.

Sumiiffiisa eqqartorneqarnerini makku ilanngunneqarput: Pineqartup sumiinnerata nassuiarneqarnerata saniatigut nungutsaaliuinerup killiffia, piginnittuunermut tunngasut, timmissat tigutsisillit avataaneersut, nalunaarsukkat qangarnitsat, allanut innersuussinerit kiisalu timmissat pineqartut sumiiffiisa nalunaarsorneri iml. allatut misissorniarnerannut pisariuminarnerinut tunngasut. Sumiiffinnik alaatsinaannermut tunngasoq makkuninnga imaqarpoq: immikkut paasisat mikisualuttaat, soorlu timmissat suunersut, ulloq misissuiffik, misissuisup aqqa, timmissat normui, kisitsinerup ilumoornera, timmissat sorliit kisinneqarsimanersut kiisalu nunanut allanut innersuussinerit. Misissuinerni najoqqutarisat - malinnaanissanut atortussatut - qulaani immikkuualuttut taakkartorneqartut ataatsimoortillugit imarivai. Nunanut allanut innersuussinerit paasissutissanik tunngaviusunik kiisalu qangali pioreersunik imaqarput. Alaatsinaattunut tunngasut alaatsinaattunut akisussaasunut innersuussiffiuvoq. Assit atorneqartut misissuinernut tunngasunut innersuussissutaapput.

Internet-ikkut tamarmik nassaarineqarsinnaapput, una atorlugu: ftp://ftp.npolar.no/Out/NordicDatabase/. Akeqanngitsumik downloaderneqarsinnaavoq. Nittartakkap taassuma atorneqarnissaanut ilitsersuut nalunaarusiamut ilanngussani nassaarineqarsinnaavoq.

Timmissat imarmiut sumiinnerinik qarasaasiatigut nalunaarsorneqarnerisa qanoq atorneqarnissaat:

Timmissat imarmiut sumiiffiinik qarasaasiatigut nalunaarsuinerup aaqqissorluakkanik nutarterneqartuaannartunillu paasissutissanik peqartuarnissaq siunertarivaa, tamatumani timmissat sumiiffiisa sumiinneri, timmissat suuneri amerlassusaallu eqqarsaatigalugit. Paasissutissat tamakku siunertanut assigiingitsunut atoriaannaassapput: ilisimatusarnernut, avammut paasisitsiniaanernut, piujuaannartitsinermut, kiisalu aqutsinermut. Paasissutissat taama ittut aqutsinermi pingaaruteqarmata piujuartitsiarnermut nungusaananilu atuinermut naalakkersuinikkut aqutsinermut pinngitsooratik ilaasariaqarput.

Paasissutissat taama katersat nunat immikkoortuini pilersaarusiornernut pingaaruteqarput, tamassumalu saniatigut pinngortitamut sunniutaasunik naliliisarnernut, alaatsinaannernut, ilisimatusarnernut assigiinngitsunut kiisalu ilinniusiornerni pingaaruteqarlutik. Qaarasaasiatigut ataatsimoortumik katersat pingaaruteqarput, tassami ataatsimut isigalugit misissuinerni atorneqarsinnaagamik, minnerunngitsumillu nunat ataasiakkaat piinnarnagit nunarsuup ilarujussua ataatsikkut missuivigineqarsinnaammat. 
Issittumi timmissat imarmiut sumiiffiinik qarasaasiatigut paasissutissanik nalunaarsuinermi najoqqutassat:

Taamatut Savalimmiunut, Kalaallit Nunaannut Island-imut Jan Mayenimut Svalbard-imullu atatilligu ataatsimoortumik qarasaasiatigut paasissutissanik katersuiniarneq ilaatigut uunga attuumassuteqarpoq: Circumpolar Seabird Group (CBird) - Conservation of Arctic Flora and Fauna (CAFF)-ip ataani sulisoq, tassaallunilu Issittormiut Siunnersuisoqatigiiffianni suleqatigiissitaliat ilaat. Nunat Avannarliit ilai qarasaasiatigut paasissutissanik ilisimatusarnermut naakalakkersuinikkullu atugassianik pilersitsereersimapput, taamatuttaaq Issittumi nunat arlallit taamaalioreersimapput. Issittoq kaajallallugu qarasaasiatigut timmissanut imarmiunut paasissutissanik katersuinnissaq CBird-ip Skotland-imi Aberdeen-imi marts-imi 2005-mi ataatsiminneranni eqqartorneqarpoq. Siunertatut saqqummiunneqartoq tigulluarneqaqaaq, imaammammi Canada Alaska-lu (USA sinnerlugu) qarasaasiatigut katersanik peqareeraluarlutik nutarterinnissartik pisariaqartimmassuk. Taamaattumik Nunani Avannarlerni pilersaarut ingerlaqqinnissamut sakkussatut pitsaasutut isigineqarpoq. Aamma paasineqarpoq Rusland-ip avannaata qeqqa maannamut qarasaasiatigut katersugaasimasunut ilaanngitsoq (paasissutissat Rusland-ip avannaata kitaani kangianilu katersat ilaareerput). Tamannali annertunerusumik paasiniartariaqassaaq.

Siunissami suliassat:

Suliarinnittussatut toqqarneqarsimasut paasivaat ataatsimoortumik qarasaasiatigut timmissat imarmiut sumiiffiinik paasisassarsiornerit nalunaarsuinerullu maannakkut suliarineqartup naammassinerani tamakkiisumik inaarsarneqarsinnaanngitsut. Siunissami naammassisassatut tikkuarneqartut makku oqaatigineqarsinaapput:

- Nunat ataasiakkaat nammineq timmissat imarmiut sumiiffiisa qarasaasiatigut nalunaarsorneri ingerlatiinnassavaat, tamatumani nutartertuarlugit, kukkunerit aaqqittarlugit, sumiiffinnut ataasiakkaanut tunngasuni kukkunerit ataasiakkat aaqqittarlugit, minnerunngitsumillu nunap qanoq pissuseqarneranut tunngasut, timmissat siaruartarnerat, sumiiffinni nungutsitsinaveersaarneq, kia nunamik piginnittuunera il.il. eqqarsaatigalugit.

- Timmissat sumiiffiinik qarasaasiatigut ataatsimoortumik nalunaarsuineq maannamut naleqqiullugu nunat peqataasut akornanni paasisat ataatsimoortumik nalilersortuarnissaannik periarfissiivoq, tamatumanilu nunarsuup immikkoortui isorartunerusut ilannguneqarsinnaallutik. Taamaakkaluartoq immikkut misissuinerit allarpassuit annertunerusumik aallarnerneqarsinnaapput:

o Atlantikup Avannaani timmissat imarmiut sumiiffii tulleriiarlugit nalunaarsorneqarsinnaapput 
o Timmissat ataasiakkat, iml. timmissat assigiinngitsut ataatsimut isigalugit ilisimatusarnikkut nalilersorneqarsinnaapput, tamatumani sumiiffii erseqqinnerusumik nalunaarsorlugit, kiisalu sumiiffiisa annertussusii sumullu ingerlaartarneri il.il.

- Nunamik eqqissisimatitsineq eqqarsaatigalugu nunani assigiingitsuni qanoq timmissat imarmiut illersorneqartiginersut nalunaarsorneqassapput.

- Timmissat nerisasassarsiortarfiisa qanoq inissisimanerisa nalunaarsornissaat aammalu sumiiffiit qanoq inissisimanersut ilanngunneqarnissaat, tamatumani timmissat assigiinngitsut timmissallu ataasiakkaat akornanni pissutsinik nalunaarsuinissaq.

- Timmissat imarmiut assigiinngitsut kisinnerini qanoq periaaseqartarnerit aammalu nungutsaaliornissaannut tunngasunik ilitsersuummik quppersagaliornissaq.

- Paasissutissanik immersuinissanut, ataatsimoortumik nalileeqatigiittarnissanut, aqutsinermut atasunik aalajangiinissanut atatillugu Internet atorlugu Nunani Avannarlerni timmissat imarmiut katersuuttarfiinik ilisimasanik nalunaarsuinernut iserfigineqarsinnaasumik pilersitsinissaq, il.il.

- Timmissat piaqqiornerisa qanoq iluatsilluartarnerinut tunngasunut atatillugu nunani allani qarasaasiatigut katersanut attaveqarsinnaaneq, tamatumani eqqarsaatigalugit timmissat nerisassaannut qanorlu sivisutigisumik uumasarnerinut paasissutissat annertunerusut pingaaruteqartullu pissarsiarisinnaarusullugit.

- Nunani pineqartuni nunap immikkoortuisa suli misissuiffigineqarsimanngitsut mississuiffigiartornissaat, taamaalillunilu timmissat sumiiffigisartagaat suli nalunaarsorneqarsimanngitsut sumiiffissillugit qanorlu isorartutigineri misissorlugit.

- Ilisimatusarnikkut naalakkersuinikkullu aqutsinikkut Atlantikumi timmissat imarmiut ilisimasaqarfigineqarnerunissaasa aqqutissiuunneqarnissaat tapersersussallugu. 


\section{Ágrip}

Skýrslan sem hér birtist fjallar um samræmingu gagnagrunna yfir sjófuglabyggðir í norrænu löndunum. Í löndunum sem liggja að NorðurAtlantshafi er að finna sjófuglabyggðir sem eru mikilvægar á heimsmælikvarða. Samanlagt verpa reglulega í pessum löndum 30 tegundir sjófugla, fjöldi byggða (varpa) er talinn nema um tíu púsundum (en oft verpur fleiri en ein tegund á sama stað) og samanlagt eru varppörin álitin vera nærri 50 milljónum. Ein tegund, haftyrðill Alle alle sem verpur mest í Grænlandi, er langalgengust sjófuglanna og eru varppörin af peirri tegund einni áætluð um 38 milljónir. Norræna ráðherranefndin lagði til fjármagn til pess að samræma snið fyrir gagnagrunna yfir sjófuglabyggðir milli norrænu landanna. bað var gert í ljósi ofangreindra staðreynda og til að fylgja eftir tillögu í samnorrænu aðgerðaáætluninni fyrir norðurslóðir.

Verkefnishópurinn:

Frá pví í desember 2002 vann norrænn hópur sem samanstóð af pátttakendum frá Grænlandi, Færeyjum, Íslandi og Noregi (vegna Jan Mayen og Svalbarða) að bví verkefni að samræma gagnagrunna yfir sjófuglabyggðir. Tilgangur pessa verkefnis eins og pað var skilgreint í umsókn var eftirfarandi:

- Samræma snið á gagnagrunnum yfir sjófuglabyggðir í Færeyjum, Grænlandi, Íslandi, Jan Mayen og Svalbarða

- Safna saman tiltækum upplýsingum og bæta pá gagnagrunna sem til voru svo beir nýttust betur

- Kanna viðeigandi gagnagrunnsforrit og hvernig útbúa mætti ýmis konar samantektir, svo sem kort

- Kanna hvort unnt sé að útbúa sameiginlegan gagnagrunn og skilgreina sameiginlegar reglur um not af honum

- Kanna hvort unnt sé að auka not af gagnagrunnssniðinu með pví að ná til annarra landa á norðurslóðum

- Taka saman skýrslu um helstu niðurstöður verkefnisins

Stöðuskýrslur:

Einn formlegur fundur var haldinn í verkefnishópnum. Par gerðu fulltrúar grein fyrir stöðu gagnagrunna yfir sjófuglabyggðir hver í sínu landi og eru pær dregnar saman hér að neðan:

Fæereyjar: Fjöldi varptegunda: 20; Fjöldi sjófuglabyggða: um 1600; Fjöldi varppara: um 1.7 milljón. Enginn gagnagrunnur var til áður en 
byrjað var á núverandi verkefni. Helstu tegundir sem eru vaktaðar eru langvía, rita og súla.

Grcenland: Fjöldi varptegunda: 21; Fjöldi sjófuglabyggða: um 3700; Fjöldi varppara: um 38.05 milljón. Gagnagrunnur var til áður en byrjað var á bessu verkefni en gera purfti breytingar á honum og uppfæra tölvuforrit. Vöktun hefur verið komið á eða gerðar tillögur um vöktun á stuttnefju, æðarfugli og kríu.

Ísland: Fjöldi varptegunda: 23; Fjöldi sjófuglabyggða: um 4500; Fjöldi varppara: um 7.5 milljón. Enginn formlegur gagnagrunnur var til við upphaf verkefnisins, bótt vísir af grunni (í excel-formi) hafi verið til fyrir ákveðnar tegundir. Vöktun nær til heildarstofns tveggja tegunda (súla, dílaskarfur). Hjá 10 tegundum eru ákveðnar byggðir vaktaðar, pó að sú vöktun gefi ekki heilstæða mynd af ástandi viðkomandi stofna á Íslandi. Engin vöktun fer fram á 10 tegundum.

Svalbarði: Fjöldi varptegunda: 18; Fjöldi sjófuglabyggða: a.m.k. 1536; Fjöldi varppara: 2,8 til 3,1 milljón. Gagnagrunnurinn sem til var parfnaðist uppfærslu, bæði forritið og uppbygging hans miðað við sameiginlegt gagnagrunnssnið. Á árinu 2004 voru sjö tegundir með í vöktunaráætlun fyrir Svalbarða (fýll, æðarfugl, hvítmáfur, rita, langvía, stuttnefja, haftyrðill).

Jan Mayen: Fjöldi varptegunda: 15; Fjöldi sjófuglabyggða: a.m.k. 92; Fjöldi varppara: um 300 púsund. Enginn gagnagrunnur var til við upphaf pessa verkefnis og sjófuglar eru ekkert vaktaðir á Jan Mayen.

Samræming gagnagrunna:

Sameiginlega gagnagrunnssniðið er gert úr premur aðaltöflum sem innihalda varplýsingu, mat á varpstærð og upplýsingar úr rannsóknareitum innan varpa. Tengdar aðaltöflunum prem eru aðrar töflur sem innihalda heimildir, athugendur og ljósmyndir.

Varplýsingartaflan inniheldur, auk staðsetningar, upplýsingar um verndarstöðu og eignarhald en einnig hvort innfluttir afræningjar séu til staðar, sögulegar upplýsingar, heimildir og hvort byggð sé heppileg til pess að fanga par fugla til merkinga eða annarra rannsókna. Varpstcerðartaflan inniheldur niðurstöður einstakra talninga, s.s. tegund, dagsetningu, athuganda, fjölda fugla, nákvæmni talningar, hvað var talið og tilvísun. Rannsóknareitataflan, sem var gerð til að geyma upplýsingar um vöktun, inniheldur ákveðnar upplýsingar sem eru að finna í tveimur fyrri töflunum. Heimildataflan inniheldur tilvísanir í birtar eða óbirtar upplýsingar. Athugandataflan inniheldur tilvísun í ábyrgarmann viðkomandi varpupplýsinga. Myndataflan inniheldur tilvitnanir til ljósmynda sem hjálpargagna við upplýsingar um viðkomandi vörp.

Forrit sem var hannað er tiltækt á netinu á eftirtalinni slóð: ftp://ftp.npolar.no/Out/NordicDatabase/. Unnt er að hala forritið niður ókeypis. Dví fylgir handbók sem er að finna í viðauka með skýrslunni. Frekari upplýsingar um einstaka gagnagrunna má nálgast hjá fulltrúa 
viðkomandi lands, sjá höfundalista. Grænlenski gagnagrunnurinn er aðgengilegur öllum á slóðinni http://www.dmu.dk/Grønland/Olie+og+Miljø/Havfuglekolonier/.

Notkun gagnagrunna yfir sjófuglabyggðir:

Tilgangur pess að taka saman upplýsingar í gagnagrunna er sá að hafa til reiðu skipulögð og uppfærð gögn um sjófuglabyggðir, fyrst og fremst staðsetningu peirra, tegundasamsetningu og stærð. Dessar upplýsingar er unnt að nota í margs konar tilgangi, til rannsókna, upplýsingamiðlunar, verndunar og stjórnunar umhverfismála. Gagnagrunnar af pessu tagi eru pví mikilvæg stjórntæki, sem ættu að vera hluti af stefnumótun í umhverfisverndarmálum og málefnum sjálfbærrar próunar í sérhverju landi. Upplýsingar í slíkum gagnagrunnum eru gagnlegar fyrir skipulagsmál, mat á umhverfisáhrifum framkvæmda, vöktun, margháttaðar rannsóknir en einnig sem grundvöllur til umhverfisfræðslu. Samræming gagnagrunna milli landa hefur ennfremur víðtækari notkunarmöguleika pví gögnin má nýta í sameiginlegum rannsóknarverkefnum yfir mun stærri svæði en pað sem tilheyrir einstökum löndum.

Snið fyrir gagnagrunna yfir sjófuglabyggðir á norðurhveli:

Hugmyndin að samræmdum gagnagrunnum fyrir Færeyjar, Grænland, Ísland, Jan Mayen og Svalbarða er að hluta til afsprengi og nátengd samvinnu sjófuglafræðinga innan Circumpolar Seabird Group (CBird). Dessi sérfræðingahópur er hluti samstarfs á sviði vöktunar og verndunar lífríkis á norðurslóðum, Conservation of Arctic Flora and Fauna (CAFF) sem er fastanefnd innan Norðurskautsráðsins (Arctic Council). Sum löndin á norðurslóðum hafa pegar komið á fót gagnagrunnum yfir sjófuglabyggðir, bæði til rannsókna og vegna stjórnunar umhverfismála, líkt og sum Norðurlandanna. Hugmyndin að samræmdum gagnagrunnum fyrir öll löndin á norðurslóðum var rædd á fundi CBird-vinnuhópsins í Aberdeen, Skotlandi, í mars 2005. Hugmyndinni var vel tekið pví bæði Kanada og Alaska (vegna Bandaríkjanna) hafa gagnagrunna sem parfnast uppfærslu og samræmda norræna sniðið virðist ágætis lausn fyrir pau. Svo virðist sem miðhluti Rússlands sé ekki hluti af peim tveimur gagnagrunnum sem til eru um rússneska sjófugla (fyrir vestur- og austurhluta Rússlands) en pað parfnast pó frekari skoðunar.

Framtíðarverkefni:

Verkefnishópurinn var sammála um að vinna við samræmda gagnagrunna var engan veginn búin við lok núverandi verkefnis. Tillögur komu fram um fjölda verkefna sem bíða úrlausnar svo sem:

- Sérhvert land viðhaldi eigin gagnagrunnum yfir sjófuglabyggðir, uppfærir með nýjum gögnum, leiðréttir villur, bætir við hliðarupplýsingum sem vantar um einstök sjófuglavörp, t.d. gerð 
búsvæðis, dreifingu byggðanna, verndarstöðu og eignarhald á landinu par sem vörpin eru, o.s.frv.

- Samræmdir gagnagrunnar gera pað kleift að skoða tiltæk gögn í víðara samhengi en annars væri hægt og má hugsa sér ýmis konar rannsóknarefni s.s.

o Taka saman skrá yfir sjófuglabyggðir í Norður-Atlantshafi

o Rannsóknarverkefni um einstakar tegundir eða tegundahópa, p. á m. nákvæmar upplýsingar um vörp peirra, stærð byggðanna, breytingar á stofnum peirra, o.fl.

- Taka mætti saman yfirlit um hve vel er staðið að verndun sjófuglabyggða í mismunandi löndum.

- Skoða búsvæðagerðir einstakra tegunda og á hvers konar stöðum vörpin eru staðsett, bæði til samanburðar innan og milli tegunda.

- Taka saman handbók um hvernig best er að telja mismunandi sjófuglategundir og hvaða stuðlum parf að beita til pess að fá sambærileg gögn.

- Próa vefaðgang til pess að nálgast gögn um norrænar sjófuglabyggðir, til að stimpla inn nýjar upplýsingar, til að taka saman gögn, svara fyrirspurnum varðandi stjórn umhverfismála, o.s.frv.

- Í tengslum við samræmda gagnagrunna mætti próa tölvuskrár með upplýsingum um varpárangur í einstökum vörpum sjófugla, fæðu, afkomu, o.fl. Mætti nota pau gögn til ýmissa flókinna greininga við rannsóknaspurningum.

- Auka parf til muna útivinnu vegna sjófuglabyggða, p. á m. skoða svæði sem eru ókönnuð, staðsetja óskráð sjófuglavörp og meta stærð peirra.

- Láta af hendi upplýsingar til viðurkenndra rannsóknarverkefna um sjófugla í Atlantshafi. 


\section{Sammendrag}

Denne rapporten beskriver resultatene fra et prosjekt som har hatt som mål å harmonisere databasene over sjøfuglkolonier i Norden. Landene rundt Nord-Atlanteren har langs sine kyster store og globalt viktige sjøfuglressurser. I regionen hekker til sammen 30 arter regelmessig og mer enn 10.000 kolonilokaliteter er kjent (ofte hekker flere arter på samme lokalitet). Antall hekkende par er i størrelsesorden 50 millioner, og alkekongen er (særlig på Grønland) den klart dominerende arten med ca 38 millioner par. På grunnlag av disse fakta, og for å oppfylle anbefalingene i Den nordiske handlingsplanen for natur- og kulturmiljøbeskyttelse i Arktis 2000-2004, samt de sirkumpolare arktiske samarbeidsforpliktelsene, bevilget Nordisk Ministerråd midler til å harmonisere databasene over sjøfuglkolonier i de nordiske landene.

Prosjektgruppen:

Fra desember 2002 arbeidet en nordisk prosjektgruppe med spørsmålet om samkjøring av databaser over sjøfuglkolonier. Gruppen hadde representanter fra Grønland, Færøyene, Island og Norge (for Jan Mayen og Svalbard).

Formålet var, som spesifisert i prosjektsøknaden:

- Etablere en harmonisert database over sjøfuglkolonier for Færøyene, Grønland, Island, Jan Mayen og Svalbard.

- Samle inn tilgjengelige, utestående data og videreutvikle/gjøre de eksisterende databasene mer anvendelige.

- Vurdere mest passende programvare til drift av databaser og utarbeidelse av grafiske presentasjoner m.m.

- Utrede sammenslåing til en felles database og definere felles regler for bruken av denne.

- Undersøke hvorvidt databaseformatet kan utvides til andre arktiske områder.

- Produsere en rapport om prosjektets resultater og konklusjoner.

Statusrapporter:

Prosjektgruppen avholdt ett formelt møte, der hvert land ga et kort oversikt over status for deres databaser over sjøfuglkolonier. Disse oppsummeres nedenfor:

Fœrøyene: antall hekkende arter: 20; antall kolonier: ca. 1.600; antall hekkende par: ca. 1,7 millioner. Ingen database var etablert forut for dette prosjektarbeidet. De viktigste overvåkingsprogrammene gjelder lomvi, krykkje og havsule. 
Grønland: antall hekkende arter: 21; antall kolonier: ca. 3.700; antall hekkende par: 38,05 millioner. En database var etablert forut for dette prosjektet, imidlertid trengtes justering av basen og mer moderne programvare. Overvåkingsprogram har blitt igangsatt eller foreslått for polarlomvi, ærfugl og rødnebbterne.

Island: antall hekkende arter: 23; antall kolonier: ca. 7.000; antall hekkende par: kanskje 7,5 millioner. Ingen offisiell database var etablert fra før, men stammen til en database (i Excel) var tilgjengelig for visse arter. Overvåking utføres for hele bestanden av to arter (havsule og storskarv). For ti arter overvåkes utvalgte kolonier, som ikke er fullt ut representative for hekkebestanden på Island. For ti arter mangler overvåking.

Svalbard: antall hekkende arter: 18; antall kolonier: minst 1.536; antall hekkende par: 2,8-3,1 millioner. Databasen over Svalbard-koloniene trengte oppgradering med hensyn programvare. Per 2004 er sju arter med i overvåkingsprogrammet for Svalbard (havhest, ærfugl, polarmåke, krykkje, lomvi, polarlomvi og alkekonge).

Jan Mayen: antall hekkende arter: 15; antall kolonier: minst 92; antall hekkende par: ca. 300.000. Ingen database var etablert forut for dette prosjektarbeidet. Det utføres ingen overvåking av sjøfugler på Jan Mayen.

Harmonisering av databasene:

Kolonidatabasen består av tre hovedtabeller: kolonibeskrivelse, tellinger fra kolonien og overvåkingsfelt. Tabeller over referanser, observatører og fotodokumentasjon er lenket til disse hovedtabellene.

Tabellene over kolonibeskrivelser inneholder informasjon om beliggenhet, vernestatus, gruneierforhold, rovdyr i området, historiske opptegnelser, referanser og opplysninger om mulighetene for å fange fugler til ringmerking eller annen forskning. Tabellene med kolonioversikter inneholder detaljer om de enkelte tellingene, så som art, dato, observatør, antall fugler, nøyaktighet, hvilken enhet som er telt, og referanser. Tabellene over prøvefelt er utformet for overvåking og inneholder en kombinasjon av detaljene i de to første hovedtabellene. Referanse-tabellene inneholder bibliografiske detaljer og arkivinformasjon. Observatørtabellene inneholder data om de ansvarlige observatører for koloniinformasjonen. Tabellene over fotodokumentasjon inneholder referanser til det fotografiske materialet som måtte finnes tilknyttet tellingene.

Programmet er tilgjengelig på denne internettlenken: ftp://ftp.npolar.no/Out/NordicDatabase/. Det kan lastes ned gratis. Manualen til programmet finnes som vedlegg til rapporten.

Bruken av databasene:

Hensikten med databasene over sjøfuglkolonier er å lagre systematisk og oppdatert informasjon, primært om beliggenhet, sammensetning og størrelse på koloniene. Grunndataene kan da lett gjøres tilgjengelig for ulike 
formål: forskning, formidling, vern og forvaltning. De er som sådan viktige redskaper for forvaltningen og bør integreres i miljøvernpolitikk/programmer for bærekraftig bruk. Dataene vil komme til nytte i lokal planlegging, vurdering av miljøpåvirkning, overvåking, forskning og som grunnlag for undervisningsmateriale. Samkjørte databaser kan anvendes bredere ved at dataene kan analyseres samlet på tvers av nasjonale grenser.

Mal for databaser over arktiske sjøfuglkolonier:

Tanken om å etablere et felles databaseformat for sjøfuglkolonier på Færøyene, Grønland, Island, Jan Mayen og Svalbard er delvis et produkt av, og er tett tilknyttet, arbeidet i den sirkumpolare sjøfuglgruppen (Circumpolar Seabird Group (CBird)). Dette er en ekspertgruppe under programmet Conservation of Arctic Flora and Fauna (CAFF), som er en av Arktisk Råds faste arbeidsgrupper. Som tilfellet var med noen av landene i Norden, hadde flere av de arktiske nasjonene allerede vel etablerte databaser for både vitenskapelige og forvaltningsmessige formål. På møtet i CBird-gruppen i Aberdeen mars 2005 ble et felles format for arktiske sjøfugldatabaser diskutert. Ideen ble svært godt mottatt. Både Canada og Alaska (for USA) har databaser som trenger oppdatering, og det nordiske formatet for databaser over sjøfuglkolonier kan være en godt utgangspunkt. Det den sentrale delen av Russland dekkes ikke av noen av de to eksisterende russiske databasene (for vestlige og østlige Russland).

Framtidig arbeid:

Prosjektgruppen erkjenner at spørsmålet om harmoniserte databaser over sjøfuglkolonier ikke er ferdig løst ved foreliggende prosjekts avslutning. Følgende framtidige arbeidsfelt ble identifisert:

- Hvert land opprettholder sine respektive databaser over sjøfuglkolonier med oppdatering, feilretting og registrering av tilleggsdata som måtte mangle for enkelte kolonier, som type habitat, koloniens utbredelse, vernestatus, eierforhold m.m.

- En harmonisert database over sjøfuglkolonier gjør det mulig å gjennomføre felles analyser av tilgjengelige data fra de deltakende landene over større områder enn det som har vært mulig tidligere. Mange typer analyser kan gjennomføres, så som:

o Utarbeide en katalog for Nord-Atlanteren over kjente sjøfuglkolonier

o Vitenskapelig vurdering av enkeltarter eller grupper av arter, inklusive detaljer om kolonier, hvor store koloniene er, utviklingstendenser m.m.

- Oversikt over vernestatus; hvor godt beskyttet koloniene er i de ulike landene. 
- Analyse av habitater og kolonienes topografi, både mellom arter og innenfor den enkelte art.

- Manual over arbeidsmetoder og omregningsfaktorer som brukes ved telling av ulike typer sjøfugler.

- Utvikling av en nettportal for tilgjengeliggjøring av en felles nordisk database over sjøfuglkolonier, med bl.a. dataregistrering, felles analyser og til bruk i forvaltningsspørsmål.

- Utvikle eksisterende programmoduler med data på hekkesuksess, næring, overlevelse osv., og som muliggjør detaljerte analyser.

- Gjennomføre feltarbeid i områder som er dårlig kartlagt, lokalisere ukjente kolonier og kvantifisere størrelsen på disse.

- Bidra til et vitenskapelig, autoritativt oversiktsverk om atlantiske sjøfugler. 



\section{Introduction}

The project reported on here is rooted in the Arctic Nordic Action Plan of the Nordic Council of Ministers (1999). The Nordic Seabird Colony Databases project is one of several seabird projects in the plan. These projects provide links to the work of the Arctic Council, a circumpolar ministerial cooperation of the Arctic countries. One of the council's permanent working groups, Conservation of Arctic Flora and Fauna (CAFF), has an expert group on seabirds (Circumpolar Seabird Group, CBird), which has had the subject of harmonized seabird breeding databases on its agenda for a long time. The Nordic Seabird Colony Databases project has been looked upon as a potential template for seabird colony databases in the Arctic countries in general.

Participation in the Nordic Seabird Colony Databases project was drawn from the Faroes, Greenland, Iceland, and Norway representing Jan Mayen and Svalbard. In the present report when reference is made to "country", in the case of Norway this is taken as Svalbard and Jan Mayen, but the total country area for the other participating countries. The project was initiated to further the development of seabird breeding colony databases in the Nordic countries. Varying amount of information on the location, size and trends in seabird colonies existed in all the countries prior to the present project. The status of this information was however widely different; in some countries all the available data had been compiled in a database while such compilation had not begun in others. In some countries organized seabird colony surveys had been undertaken, of at least part of the country area in question, while only incidental information was available from others. It follows that the countries are differentially known as regards their seabird colony resources. The completeness of the available information also depends on the species. Some species may be well surveyed, particularly those which have only a few colonies and are relatively uncommon. Others, in particular those with many and widespread colonies, are less well covered. Although their existence may be known many seabird colonies have never been properly surveyed for their size and detailed distribution of the birds.

For three of the above five countries colony databases existed prior to the project although the work on these had not necessarily been completed. Work on databases for seabird colonies is in essence never finalized since changes are constantly occurring, and new data are continually being collected, by professional ornithologists and amateur bird observers. Seabird colony databases are in reality part of the general environmental conservation agenda. Such databases therefore should be parts of the conservation policy of the participating countries, if they are not al- 
ready, to be used as a management tool for many different purposes. It is hoped that this project will draw better attention to this important aspect.

A preliminary exercise revealed that all the seabird colony databases that existed prior to the present project were different in structure. Harmonization was needed if data over the whole $\mathrm{N}$-Atlantic was to be compiled and compared. Some of the databases were totally lacking modern forms of graphic presentation. It was recognized that an in-depth look at the existing databases and work towards a more complete database format was needed.

With the above information and direction, the main initial objectives were developed as follows:

- Establish a harmonized database of seabird colonies for Faroes, Greenland, Iceland, Jan Mayen, and Svalbard

- Collect available outstanding data and refine the present databases to make them more applicable

- Explore the most appropriate computer software for holding databases and for preparing products, such as graphic presentations

- Explore how to assemble a joint database and define common rules for its use

- Explore if the database format can be expanded to other Arctic regions Produce a report on the results and main findings of the project

It was clear from the start that the project had to be centered on the existing colony data and only very limited new data could be collected, although surveys were badly needed for many regions or species. Therefore the current databases included information of varying details, both in terms of coverage and species. Future efforts need to focus more effectively on information-gathering, once the basic harmonized database format has been developed. 


\section{Present status of Nordic seabird colony databases}

Seabird colony information of different depth was available in all the participating countries prior to the present project. Below are descriptions of the status of these data in each of the participating countries. These include among others description of the seabird species and populations, the status and size of the databases, the status of seabird monitoring programs, main knowledge gaps, and the global importance of the seabird resources. These overviews are based on presentations given at the meeting of the project group in Iceland in December 2002. 


\subsection{Faroes}

\section{Introduction}

The Faroes hold a substantial part of the seabirds in the East Atlantic and a significant part of the world population of the European Storm Petrel Hydrobates pelagicus breed on the islands (BirdLife International 2004). Many of the seabirds are breeding in dense colonies and all the cliffs where Common Guillemots Uria aalge, Atlantic Puffins Fratercula arctica and Kittiwakes Rissa tridactyla breed together are of international importance (Grimmett and Jones 1989).

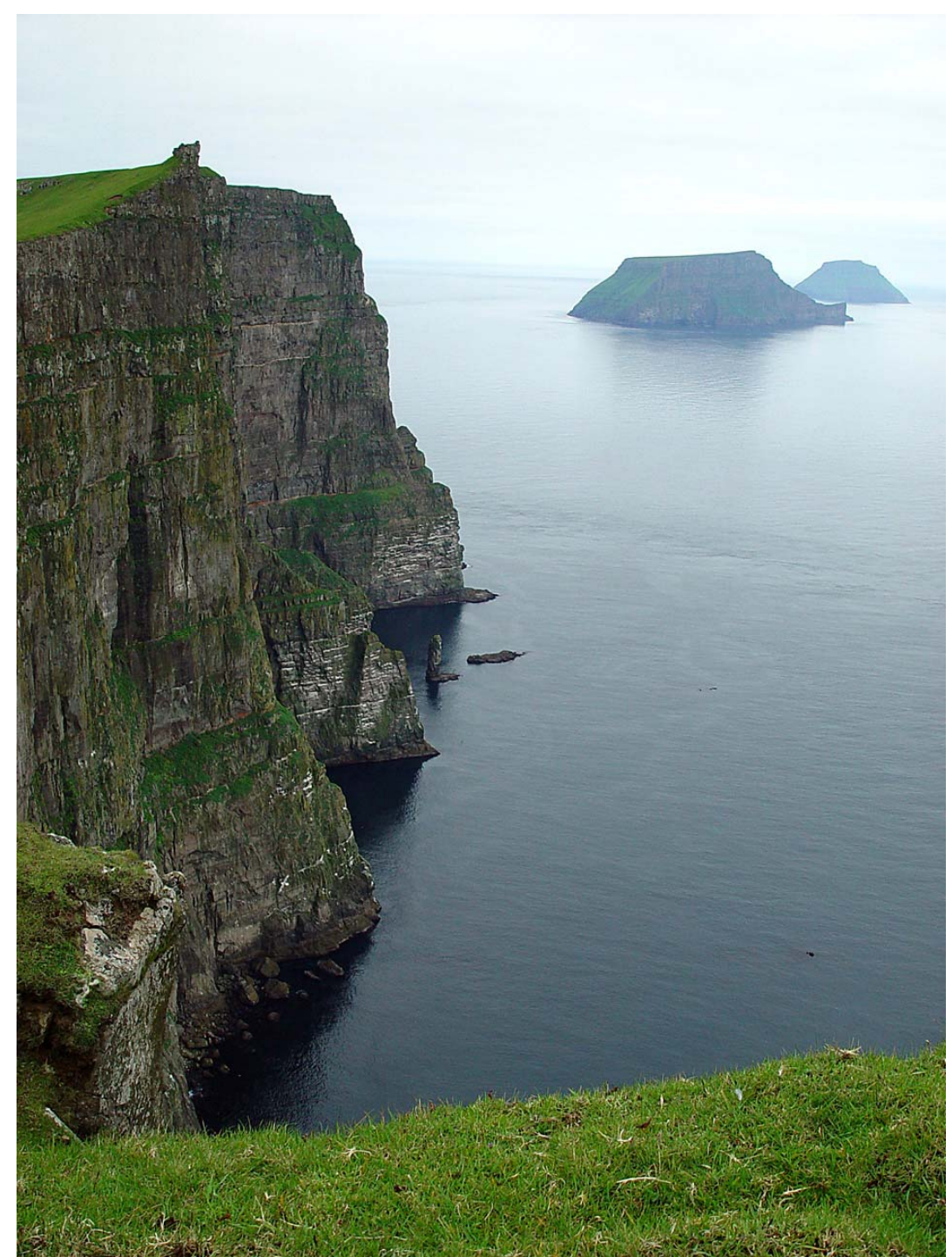

Spectacular scenery along the $390 \mathrm{~m}$ high west coast of Skúvoy, Faroe Islands. In the background are the islands Stóra Dímun and Lítla Dímun. All these islands hold important breeding seabird populations. Photo: Bergur Olsen, July 2003. 


\section{The database}

There is no database for seabird colonies in the Faroes so the present project on a Nordic Seabird Colony Database will be the basis for the Faroese database. For further information contact the author.

\section{The species and population sizes}

Twenty seabird species breed regularly in the Faroe Islands (Table 1). A small population of Great Cormorant Phalacrocorax carbo was breeding in the early 1900s but they stopped breeding around the 1950s. The figures in Table 1 is from the most recent list of birds seen in the Faroes (Jensen et al. 2004), and the total number of seabirds breeding in the Faroes is now estimated at about 1.7 million of pairs.

Table 1. Estimated numbers (in pairs) of seabirds breeding in the Faroes and the total number of colonies for each species.

\begin{tabular}{lrr}
\hline Species & Breeding pairs & Number of colonies \\
\hline Northern Fulmar Fulmarus glacialis & 600.000 & 500 \\
Manx Shearwater Puffinus puffinus & 25.000 & 15 \\
Storm Petrel Hydrobates pelagicus & 250.000 & 20 \\
Leach's Petrel Oceanodroma leucorrhoa & 1.000 & 2 \\
Gannet Morus bassanus & 2.350 & 1 \\
Shag Phalacrocorax aristotelis & 1.500 & 30 \\
Common Eider Somateria mollissima & 6.000 & 300 \\
Arctic Skua Stercorarius parasiticus & 900 & 70 \\
Great Skua Stercorarius skua & 500 & 40 \\
Arctic Tern Sterna paradisaea & 7.600 & 70 \\
Black-headed Gull Larus ridibundus & 150 & 5 \\
Common Gull Larus canus & 1.000 & 40 \\
Lesser Black-backed Gull Larus fuscus & 9.000 & 100 \\
Herring Gull Larus argentatus & 1.500 & 75 \\
Great Black-backed Gull Larus marinus & 1.200 & 75 \\
Kittiwake Rissa tridactyla & 160.000 & 50 \\
Common Guillemot Uria aalge & 100.000 & 25 \\
Razorbill Alca torda & 4.500 & 15 \\
Black Guillemot Cepphus grylle & 3.500 & 100 \\
Atlantic Puffin Fratercula arctica & 550.000 & 100 \\
\hline
\end{tabular}

\section{Number of colonies}

The number of colonies, counted per species, is about 1600 (Table 1). The colonies of the Great Skua (Bayes et al. 1961, Bloch unpubl.), Gannet (Olsen and Permin 1974, Olsen unpubl.), Arctic Skua (Bengtson and Bloch 2003), Atlantic Puffins (Harris 1984), Arctic Tern, Kittiwake, and the Common Guillemot (Olsen unpubl.) are mapped (see Figure 1). Also the gulls were censused and mapped in 1981 (Bloch and Sørensen 1984, Bloch unpubl.) while the figures for the other colonies are rough estimates. 
Figure 1. Distribution of the seabird colonies in the Faroes. Presently the colonies of Common Guillemot, Atlantic Puffin, Kittiwake, Arctic Skua, Great Skua, Arctic Tern and Gannet are included in the Faroese database. Most colonies of Manx Shearwater, Storm Petrel, Shag, Black Guillemot, Common Eider and the gulls are known locally but have not been compiled for the database.

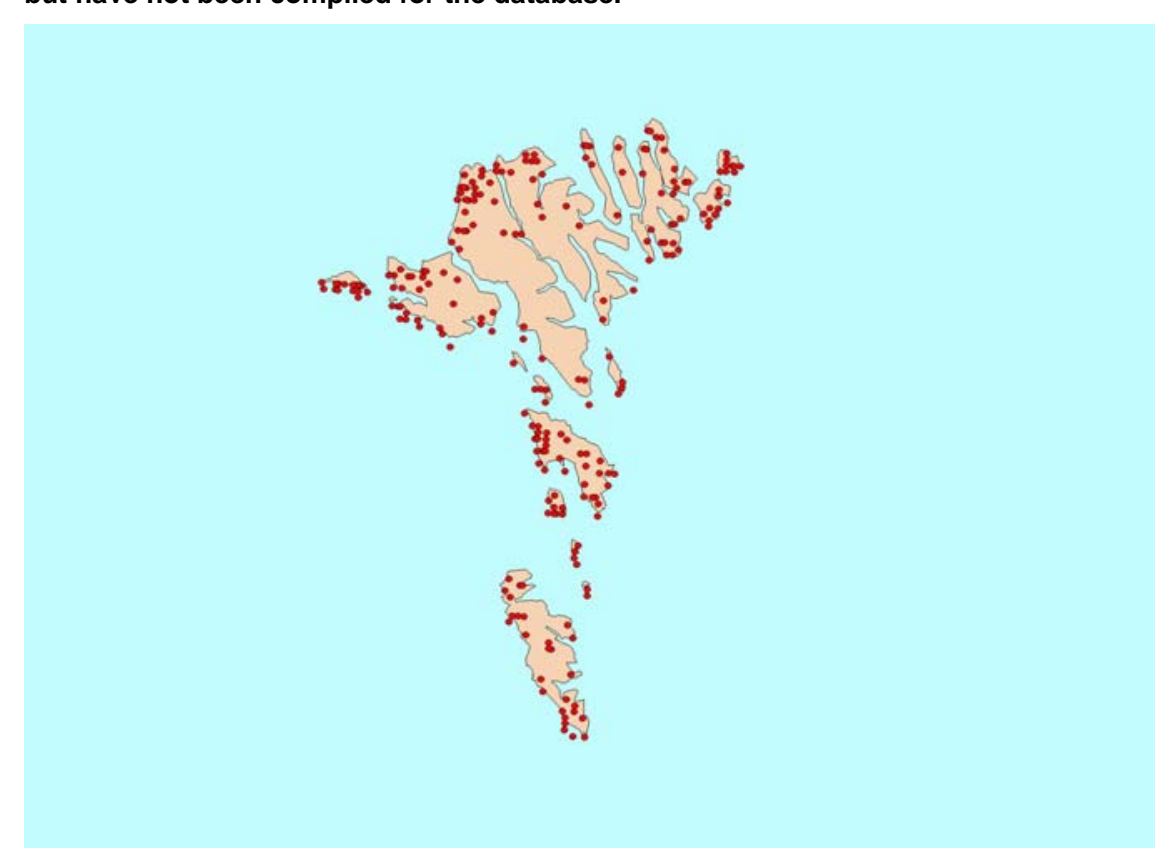

For many of the seabird species it is difficult to define what is a colony, and the number of colonies varies depending on how they are defined. As many of the seabirds e.g. Common Guillemots, Razorbills and Kittiwakes breed in the same areas, the total number of seabird colony sites are lower than the total number of colonies.

\section{Main monitoring programs}

The main monitoring program has been on Common Guillemots, Kittiwakes and Gannets. The Guillemot colonies were first mapped in the 1940s (Ferdinand 1947) and the total population of Guillemots was first censused in 1972 (Dyck and Meltofte 1973, 1975). The mapping and census of Common Guillemots was repeated in 1987 and 1997-99, and at the same time the total population of Kittiwakes were also mapped and counted (Olsen unpubl.). It is planned to continue the census of Common Guillemots and Kittiwakes every $10^{\text {th }}$ year. The Gannet colony has been censused many times (see Olsen and Permin 1974); the last two times in 1985 and 1995 (Olsen unpubl.) and it is planned to continue every $10^{\text {th }}$ year. Arctic Tern colonies were monitored in 2003 and 2004 and it is planned to continue this annually (Olsen unpubl.). 


\section{Time series}

A seabird cliff, Høvdin, on Skúvoy is used as a study area for the cliff breeding birds. Since 1972 the attending Common Guillemots on Høvdin have been monitored once a year but 1975 (Olsen 1992). The number of Common Guillemots on each ledge has been noted separately and also the Fulmars that attend the Common Guillemot ledges. Since 1989 the relative production of Kittiwake chicks has been monitored each year and since 2001 the numbers of nests and birds also have been monitored. Also the numbers of Fulmars and chicks have been monitored since 2001.

\section{Main data gaps and concerns}

More detailed estimates are needed, especially for our largest populations; Fulmars and Atlantic Puffins. Also it is important to map and census the Manx Shearwater, the Storm Petrel and Leach's Petrel colonies as well as the colonies of Shags and Black Guillemots. The Common Eider breed very scattered, but it would be good to have a better knowledge about the population and its distribution. The gulls were censused in 1981 (Bloch and Sørensen 1984) but the number has certainly changed since then, and a repetition of the estimate would give some information on the population trends.

The time series that are obtained on the study area Høvdin may not be representative for the whole Faroes, so more study plots are needed to have representative data. Also there is a general demand for breeding biology information for the Faroese seabirds.

Bergur Olsen 


\subsection{Greenland}

\section{Introduction}

Greenland holds significant breeding segments of some of the North Atlantic colonial species. The most important are Little Auk (perhaps 80\% of the world population), Brünnich's Guillemot (5-10\% of the North Atlantic population), Kittiwake (8-15\% of the North Atlantic population), Arctic Tern (5-10\% of the North Atlantic population), Black Guillemot (10-50\% of the North Atlantic population) and Iceland Gull (100\%, the subspecies glaucoides) (Nettleship and Evans 1985, Boertmann et al. 1996).

When offshore oil exploration in West Greenland was re-vitalised in early 1990s, it was decided to establish a database over the seabird breeding colonies in Greenland. The aim was to have background data readily available for impact assessments of oil exploration activities and also for monitoring and management of breeding seabird populations in Greenland. Several general colony surveys were carried out in the early 1990s and a general survey was also carried out in 2003 with the purpose to update the historical information in the database (Boertmann et al. 1996, Boertmann 2004). Targeted surveys or monitoring have been carried out for Brünnich's Guillemot (Evans and Kampp 1991, Falk and Kampp 1997, 1998, 2001, Kampp 1990, Kampp and Falk 1994, Kampp et al. 1994), Little Auk (Kampp et al. 1987, Boertmann and Mosbech 1998, Egevang et al. 2003), Common Eider (Christensen and Falk 2001, Merkel 2002), Ivory Gull (Gilg et al. 2004), and Arctic Tern (Egevang and Boertmann 2003). 


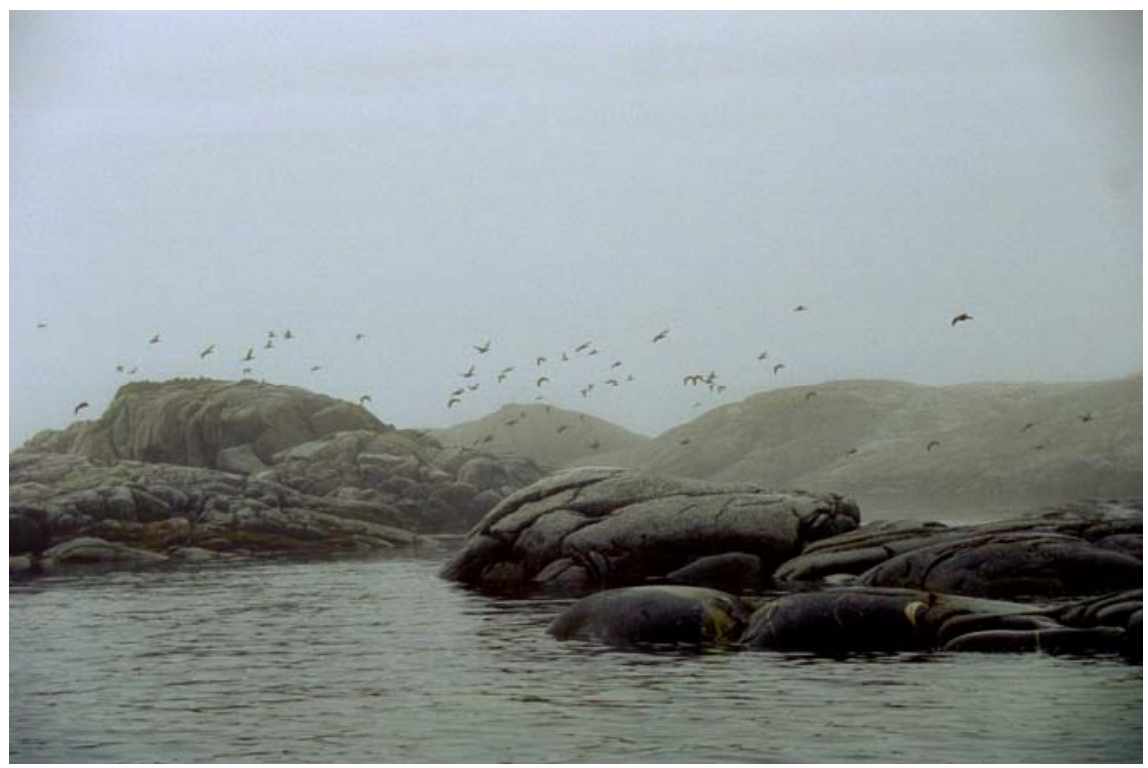

A recently discovered colony of Common Eiders (seen in flight) nesting on some barren wind swept islets just east of Cape Farewell, South Greenland. Due to fog it was not possible to make a thorough survey, but some hundred pairs nested on the islands in 2003. Photo: David Boertmann, 2003.

\section{The database}

The Greenland seabird database covers entire Greenland, although the focus is on the west coast (from Kap Farvel at $60^{\circ} \mathrm{N}$ in the south to the Thule District in the North at $79^{\circ} \mathrm{N}$ ), and the information from North and East Greenland is generally very limited.

In total, the database contains information from 1551 sites (see Figs 1 and 2) with colonial breeding seabirds (92\% are situated in West Greenland), and in total there are 6877 entries in the species/survey part of the database (January 2004 status). The Greenland database is accessible to the public at http://www.dmu.dk/Grønland/Olie+og+Miljø/Havfuglekolonier/. 
Figure 1. Distribution of the seabird colonies in the northern half of Greenland as recorded in the Greenland Seabird Colony Database.

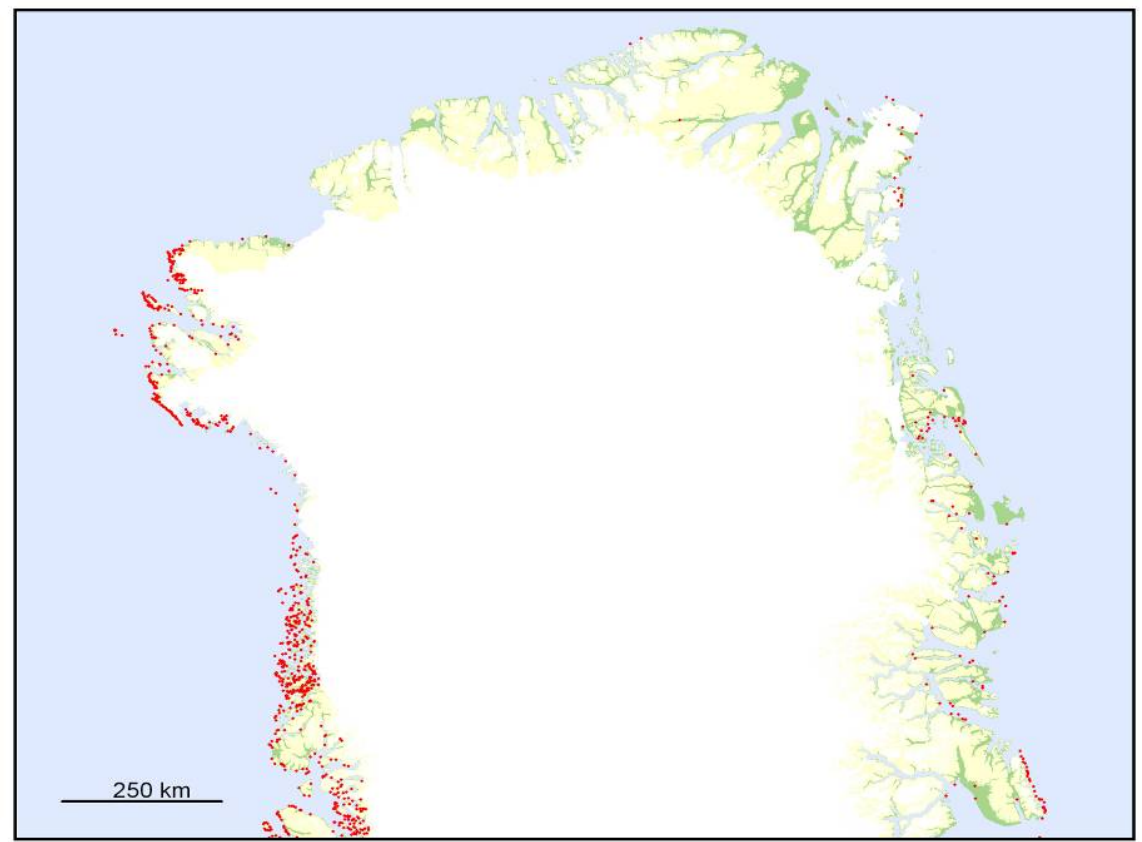

Figure 2. The distribution of seabird colonies in the southern half of Greenland, as recorded in the Greenland Seabird Colony Database.

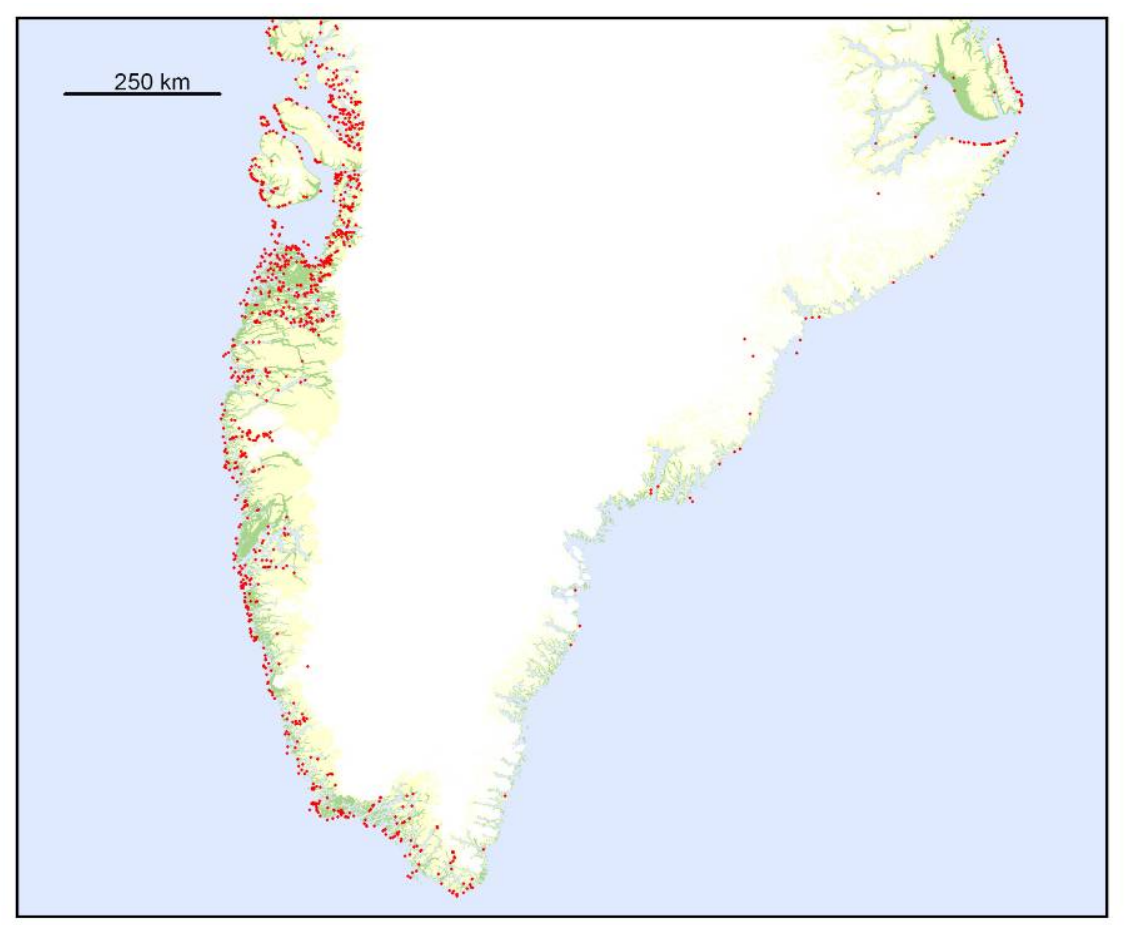

The database includes all the colonial seabird species breeding in Greenland. 


\section{The species}

Twenty-one species of colonial seabird species breed in Greenland, although a few only irregularly (Table 2). In addition, a few non-colonial species, such as Arctic Skua and Red-breasted Merganser, also breed. These are sometimes included in the database, if they occur together with colonial seabird species.

Table 2. Colonial seabirds breeding in Greenland.

\begin{tabular}{|c|c|c|c|c|c|}
\hline Species & $\begin{array}{l}\text { No. of colonies } \\
\text { recorded in } \\
\text { database* }^{\star}\end{array}$ & $\begin{array}{l}\text { Estimated no. of } \\
\text { pairs/individuals in } \\
\text { Greenland }^{\star \star}\end{array}$ & & $\begin{array}{l}\text { Quality of } \\
\text { estimate }\end{array}$ & Sources ${ }^{* * *}$ \\
\hline Northern Fulmar & 31 & $>80,000$ & $\mathrm{P}$ & Low & 1 \\
\hline Great Cormorant & 207 & 5000 & $\mathrm{P}$ & Medium & 2,3 \\
\hline Common Eider & 293 & $<25.000$ & $\mathrm{P}$ & Low & $1,8,11,12$ \\
\hline Ross's Gull & 2 & $0-5$ & $\mathrm{P}$ & Medium & $13,14,15$ \\
\hline Sabine's Gull & 17 & $<500$ & $\mathrm{P}$ & Medium & 1,4 \\
\hline Black-headed Gull & 5 & $<50$ & $\mathrm{P}$ & Low & 1 \\
\hline Lesser Black-backed Gull & 32 & $<1000$ & $\mathrm{P}$ & Medium & $1,3,8$ \\
\hline Herring Gull & 6 & $<50$ & $\mathrm{P}$ & Medium & $1,3,8$ \\
\hline Iceland Gull & 364 & 100.000 & $\mathrm{P}$ & Low & 1,3 \\
\hline Thayer's Gull & 1 & 0 & & Low & 1,5 \\
\hline Glaucous Gull & 518 & 100.000 & $P$ & Low & 1,3 \\
\hline Glaucous/Iceland Gull & 289 & - & & - & 1 \\
\hline Great Black-backed Gull & 218 & $3000-5000$ & $\mathrm{P}$ & Low & 1 \\
\hline Black-legged Kittiwake & 249 & $80,000-100,000$ & $\mathrm{P}$ & Low & 1 \\
\hline Ivory Gull & 14 & $<1000$ & $\mathrm{P}$ & Low & 9,10 \\
\hline Arctic Tern & 243 & 65.000 & $\mathrm{P}$ & Medium & 6 \\
\hline Common Guillemot & 6 & $1500-2000$ & I & Low & 1 \\
\hline Brünnich's Guillemot & 23 & 350,000 & $\mathrm{P}$ & High & 7 \\
\hline Razobrill & 243 & $3000-6000$ & $\mathrm{P}$ & Low & 1,3 \\
\hline Black Guillemot & 793 & $100-200.000$ & $\mathrm{P}$ & Low & 1,3 \\
\hline Little Auk & c. 100 & 38 mill. & $\mathrm{P}$ & Low & $1,16,17,18,19$ \\
\hline Atlantic Puffin & 69 & $5-10,000$ & $\mathrm{P}$ & Low & 1,3 \\
\hline
\end{tabular}

* Not all necessarily occupied at present.

** $\mathrm{P}=\mathrm{Pairs} ; \mathrm{I}=$ Individuals.

*** 1: Boertmann et al. 1996, 2: Boertmann and Mosbech 1997, 3: NERI unpubl., 4: Forchhammer and Maagaard 1999, 5: Boertmann 2001, 6: Egevang and Boertmann 2003, 7: Falk and Kampp 2001, 8: Boertmann 2004, 9: Boertmann 1996, 11 Merkel 2002, 12: Christensen and Falk 2001, 13: Boertmann 1994, 14: Frich 1997, 15: Falk et al. 1997, 16: Kampp et al. 1986, 17: Kampp et al. 1987, 18: Boertmann and Mosbech 1998, 19: Egevang et al. 2003.

\section{Monitoring}

Monitoring programs have been initiated or proposed for Brünnich's Guillemots, Common Eiders and Arctic Terns (Falk and Kampp 1997, 1998, Merkel and Nielsen 2002, Egevang and Boertmann 2003). All are species which are harvested and which have shown population declines in recent decades.

\section{Time series}

Only a few colonies have been surveyed regularly over a longer time span. As an exceptional example a single Great Cormorant colony was surveyed 8 different years since 1982 . 


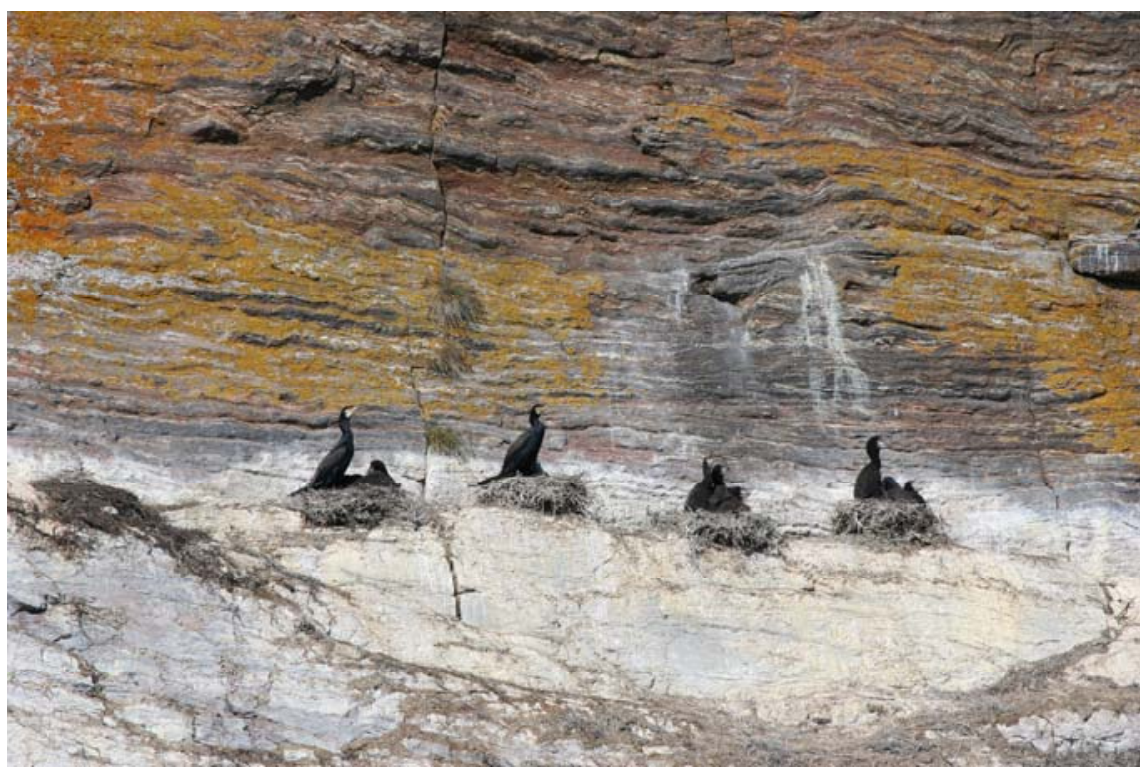

Great Cormorants breed in small colonies in the fjordlands and along the outer coasts of central West Greenland. Photo: David Boertmann, July 2005.

\section{Main data gaps and concerns}

Extensive regions of West Greenland are fairly well surveyed for seabird colonies (e.g. Boertmann et al. 1996, Boertmann 2004, Christensen and Falk 2001, Merkel and Nielsen 2002). There are however some areas where recent surveys and information is lacking, such as the Fiskefjord complex, the large fjords Afersiorfik and Nordre Strømfjord. And also between species there is variation in how detailed the information is.

East and North Greenland has never been systematically surveyed for seabird breeding colonies, except for some more restricted areas. Most of the information from these two large regions is also rather old and far from up-to-date.

The most immediate concern is, that in order to keep the database operational, the information need to be updated regularly, and field surveys should be carried out with regular intervals. Moreover, in addition to the monitoring programs for Brünnich's Guillemot and Common Eider a monitoring programme should also be initiated for Kittiwake, as the breeding population of this harvested species seems to be declining (Nyeland 2004). Then there is a general demand for breeding biology information of all the Greenland seabirds.

\section{Survey strategy}

To improve the information quality of the database, colonies should be surveyed at intervals not longer than 10 years. The population size of each colony should then be estimated either by: general surveys and counts of nests and/or birds; special methods for large colonies (for 
example by photo documentation); and special methods for species difficult to detect (for example Common Eider). Targeted monitoring programs of colonies with selected species of concern should be initiated (as for Brünnich's Guillemot). And finally breeding biology study programmes should be initiated for selected species.

David Boertmann and Anders Mosbech 


\subsection{Iceland}

\section{Introduction}

It is clear that Iceland has a high global responsibility for seabirds in general, as a home to perhaps 30 million individuals. Of certain species Iceland holds substantial parts of the respective world populations, especially the Razorbill Alca torda, Atlantic Puffin Fratercula arctica, Great Skua Stercorarius skua, Leach's Petrel Oceanodroma leucorrhoa, and Storm Petrel Hydrobates pelagicus.

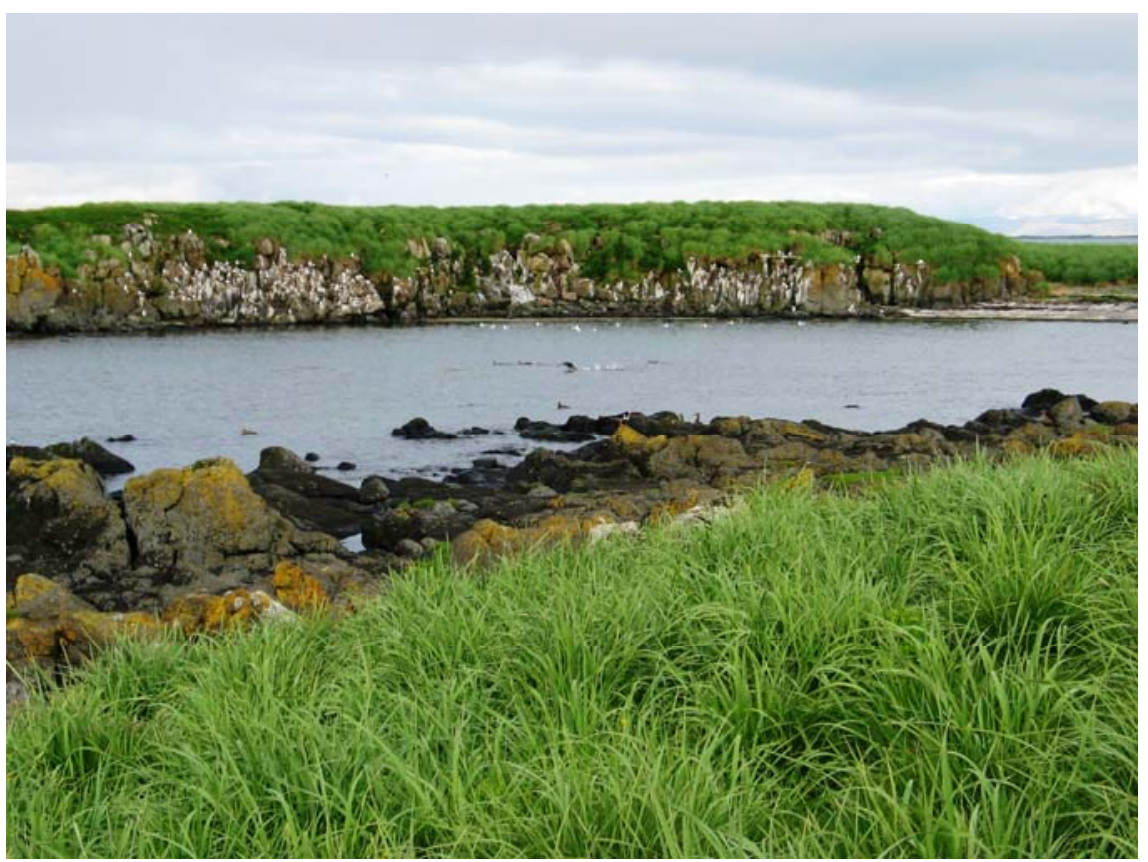

The Breiðafjörður archipelago, W-Iceland, holds about 3000 islands and harbours rich seabird life. Sýrey island, shown here, has a large Atlantic Puffin colony on the grassy areas, as well as a good-sized Common Eider colony. A Black-legged Kittiwake colony became established in 1985, and Arctic Terns nest on the beach. Photo: Aevar Petersen, 16.6.2004.

\section{The database}

The Icelandic Seabird Colony Registry was established as to support the efforts of the CAFF working group and its emphasis on seabird conservation in the circumpolar Arctic countries. The database has the aim of compiling seabird colony data for management, conservation and research purposes. This was intended to include data for all the colonynesting seabirds, even those species which may nest dispersed single or a few pairs in a place. Although basic data have been compiled on all the species, the information has not been entered for all the species because 
of the lack of time and other resources. The Icelandic Seabird Colony Registry now contains over 12000 entries (status in January 2004). These include known colony sites for which no quantitative data are available, information for colony sizes, multiple for some colonies, which are monitored, and colonies, which have disappeared for one reason or another. Currently around 3800 colony sites are included in the database (Figure 4), but it is known that considerable numbers are still to be registered. For further information contact the author.

Figure 4. The distribution of seabird colony sites currently included in the Icelandic Seabird Colony Registry database. For several species, especially the gulls, all the data available have not been entered into the database. Besides the colony distribution is only partially known for some species, such as Fulmar, Arctic Tern, Great Black-backed Gull, Lesser Black-backed Gull, Atlantic Puffin, and Black Guillemot.

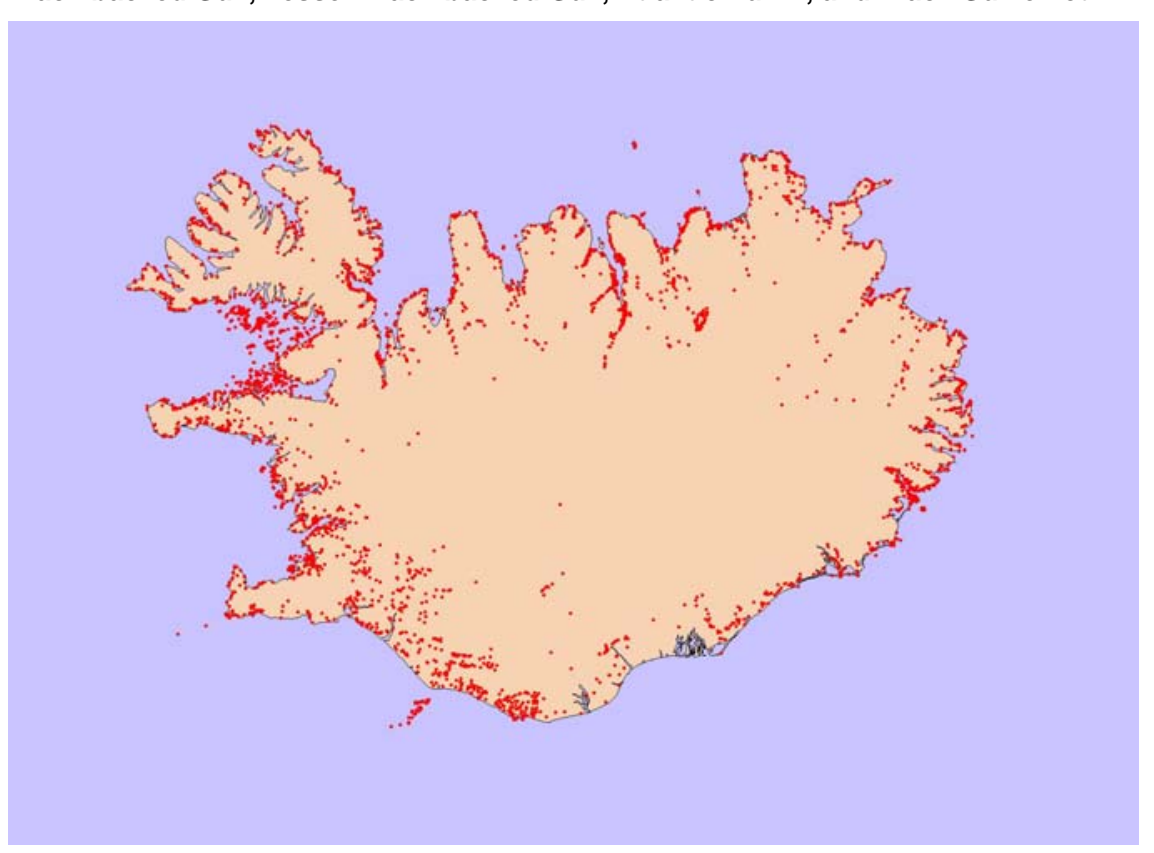

\section{The species}

Twenty-three seabird species now breed regularly in Iceland. One further species, the Little Auk Alle alle, has just recently stopped nesting in the country. These species form the framework for the Icelandic Seabird Colony Registry, which primarily contains data on (1) colony locations, (2) colony sizes, and (3) censusing or monitoring results.

\section{Population sizes}

Population sizes have been estimated for all species (Table 3) but the data vary considerably in quality (Petersen 2000). Some species estimates have been arrived at from careful censuses. For others not even all the colonies have been registered, let alone counted carefully. Presently a 
rough estimate indicates that as many as 7.5 million seabird pairs may breed in Iceland.

Table 3. Estimated numbers of seabird species breeding in Iceland.

\begin{tabular}{llll}
\hline Species & $\begin{array}{l}\text { Estimated } \\
\text { numbers of } \\
\text { breeding pairs }\end{array}$ & Year & Reference \\
\hline Northern Fulmar Fulmarus glacialis & $1-2$ million & 1995 & Asbirk et al. 1997 \\
Gannet Sula bassana & 28.535 & 1999 & Gardarsson 2005 \\
Shag Phalacrocorax aristotelis & $8-9.000$ & 1995 & Gardarsson 1979; Petersen 1998 \\
Great Cormorant P. carbo & 4.030 & 2003 & A. Gardarsson in Ingolfsson 2005 \\
Leach's Petrel Oceanodroma leucorrhoa & $80-100.000$ & 1995 & Asbirk et al. 1997 \\
Storm Petrel Hydrobates pelagicus & $50-100.000$ & 1995 & Asbirk et al. 1997 \\
Manx Shearwater Puffinus puffinus & $7-10.000$ & 1995 & Asbirk et al. 1997 \\
Common Eider Somateria mollissima & 300.000 & 1995 & Asbirk et al. 1997 \\
Great Skua Stercorarius skua & 5.400 & $1984-85$ & Lund-Hansen and Lange 1991 \\
Arctic Skua S. parasiticus & $5-10.000$ & 1995 & Asbirk et al. 1997 \\
Arctic Tern Sterna paradisaea & $250-500.000$ & 1995 & Asbirk et al. 1997 \\
Black-headed Gull Larus ridibundus & $25-30.000$ & 1995 & Asbirk et al. 1997 \\
Common Gull L. canus & 700 & 2000 & Petersen and Thorstensen 2004 \\
Great Black-backed Gull L. marinus & $15-20.000$ & 1998 & A. Petersen, unpubl. \\
Lesser Black-backed Gull L. fuscus & 25.000 & 1995 & Asbirk et al. 1997 \\
Herring Gull L. argentatus & $5-10.000$ & 1995 & Petersen 1998 \\
Glaucous Gull L. hyperboreus & 8.000 & 1995 & Asbirk et al. 1997 \\
Black-legged Kittiwake Rissa tridactyla & 630.000 & $1983-85$ & Gardarsson 1996 \\
Atlantic Puffin Fratercula arctica & $2-3$ million & 1995 & Asbirk et al. 1997 \\
Razorbill Alca torda & 378.390 & $1983-85$ & Gardarsson 1995 \\
Common Guillemot Uria aalge & 992.340 & $1983-85$ & Gardarsson 1995 \\
Brünnich's Guillemot U. lomvia & 579.450 & $1983-85$ & Gardarsson 1995 \\
Black Guillemot Cepphus grylle & $10-15.000$ & 1998 & A. Petersen, in prep. \\
\hline & & &
\end{tabular}

\section{Numbers of colonies}

The number of seabird colonies, counted per species, is estimated around 7000 if each species is counted (Table 4). These are inaccurate figures since for many species the precise number is still unclear, as inventories of colonies have not been carried out for many regions, let alone colonies censused. The worst registered species, include Fulmar, Great Blackbacked Gull, Lesser Black-backed Gull, and Arctic Tern. 
Table 4. Estimated numbers of colonies of each seabird species breeding in Iceland.

\begin{tabular}{ll}
\hline Species & $\begin{array}{l}\text { Numbers of colonies } \\
\text { (accurate figures or estimates) }\end{array}$ \\
\hline Northern Fulmar Fulmarus glacialis & 1500 \\
Gannet Sula bassana & 9 \\
Great Cormorant Phalacrocorax carbo & 115 \\
Shag P. aristotelis & 150 \\
Leach's Petrel Oceanodroma leucorrhoa & 12 \\
Storm Petrel Hydrobates pelagicus & 10 \\
Manx Shearwater Puffinus puffinus & 7 \\
Common Eider Somateria mollissima & 630 \\
Great Skua Stercorarius skua & 35 \\
Great Black-backed Gull Larus marinus & 300 \\
Lesser Black-backed Gull Larus fuscus & 300 \\
Glaucous Gull L. hyperboreus & 150 \\
Herring Gull L. argentatus & 170 \\
Common Gull L. canus & 120 \\
Black-headed Gull L. ridibundus & 600 \\
Black-legged Kittiwake Rissa tridactyla & 250 \\
Arctic Tern Sterna paradisaea & 1500 \\
Razorbill Alca torda & 40 \\
Common Guillemot Uria aalge & 40 \\
Brünnich's Guillemot U. lomvia & 30 \\
Atlantic Puffin Fratercula arctica & 650 \\
Black Guillemot Cepphus grylle & 250 \\
Total & 6868 \\
\hline
\end{tabular}

It should be noted that the actual number of seabird colony sites is much less than 7000 , perhaps 4500 . This is because at many locations more than one species is found breeding, occasionally as many as 10-11 species together at one and the same site.

\section{Main monitoring programs}

Only a couple of Icelandic seabird species are monitored in a fully representative way; Cormorant and Gannet (cf. Petersen 2003). Several seabird species are monitored locally, but in no way do these cover the respective Icelandic populations in a representative manner. These include Fulmar, Shag, Kittiwake and Arctic Tern in the Breiðafjörður Bay and islands around Flatey (NW-Iceland). Brünnich's Guillemot and Common Guillemot are monitored at two sites, Langanes (NE-Iceland) and Krísuvíkurberg (SW-Iceland). More extensive monitoring of Black Guillemots has taken place annually on about twenty little islands in Breiðafjörður for 30 years, and annually for a few years at Steingrímsfjörður (NW-Iceland). Black-headed Gulls and Common Gulls are censused every fifth year in the Eyjafjörður region, N-Iceland. A country-wide monitoring program for Common Eider has recently been initiated.

\section{Time series}

The longest time series for the total breeding population is available for the Common Eider (down-export data), for about a century, and the Gan- 
net, about half a century. A 30 year long series is available for the Cormorant population. Total population censuses are available for certain species, such as Shag, Great Skua, Razorbill, Brünnich's Guillemot, Common Guillemot, and Kittiwake, while monitoring data only exist at individual colonies, not necessary representative for the Icelandic population as a whole.

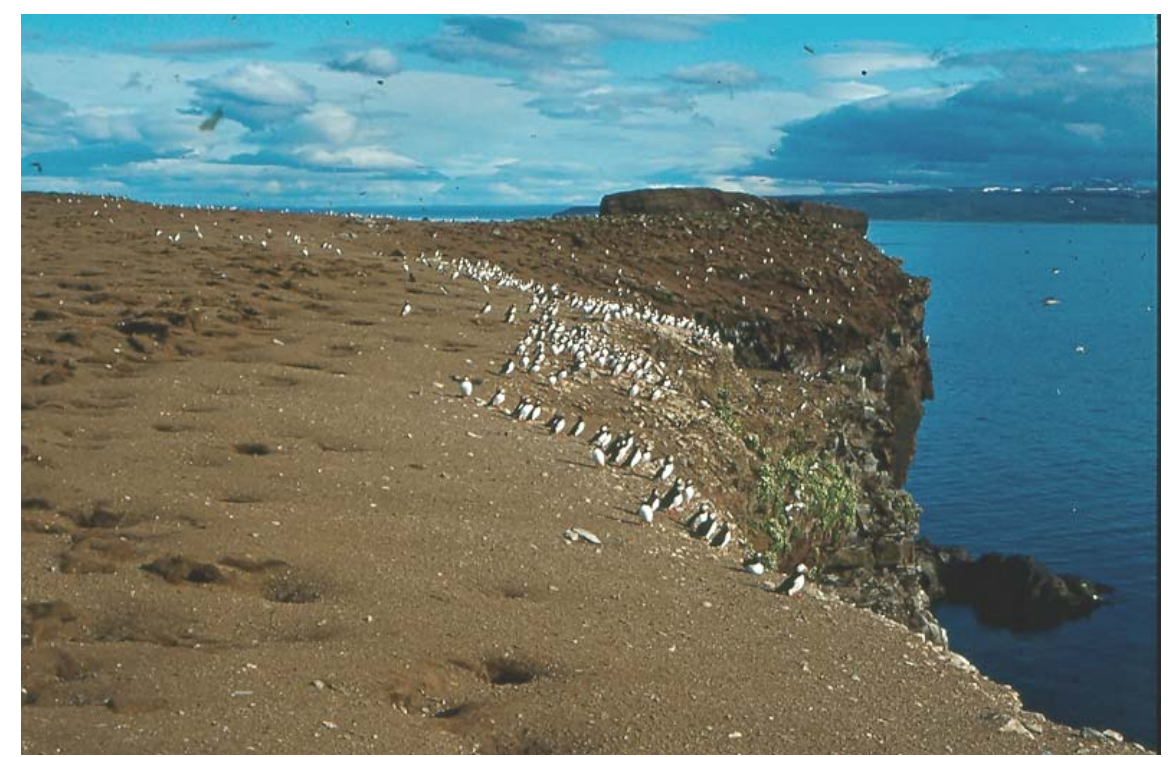

The Atlantic Puffin is the most numerous seabird species breeding in Iceland. Colonies are found all around the island, although the most important areas are the Westman Islands, south of Iceland, and the Breiðafjörður islands, West-Iceland. This picture is, however, taken on Lágey, one of the two Mánáreyjar islands, off North-Iceland. Photo: Aevar Petersen, 21.6.1981.

\section{Main data gaps and concerns}

Reasonably accurate population figures exist for only a few Icelandic seabird species, in particular Gannet, Cormorant, Shag, Great Skua, Common Gull, Kittiwake, Razorbill, Common Guillemot, and Brünnich's Guillemot. For most others the population estimates are based on variably accurate information. More detailed estimates are needed, and repetition of old estimates, which would also give some information on recent population trends.

Sufficient monitoring activity is still lacking for most Icelandic seabirds. No monitoring takes place for about half of all the species, and for most of the others only locally and by no means fully representative for the respective Icelandic breeding populations. It is hoped that national monitoring programs can be formulated, or existing ones expanded. Such plans have been developed for some species, i.e. Common Eider (Petersen 2001), murres (Petersen 2002), Black Guillemot (Petersen in prep.), Common Gull (Petersen and Thorstensen 2004), and Black-headed Gull (Petersen and Thorstensen 1993, 2005). The implementation of these 
programs is more challenging, but these could be carried out if amateur bird watchers are willing to participate, esp. if some financial support is forthcoming.

\section{Aevar Petersen}




\subsection{Jan Mayen and Svalbard}

\section{Introduction}

Svalbard and Jan Mayen support large populations of seabirds, some of which represent significant proportions of the global populations of individual species, and hence are of international importance. This includes among others the Little Auk Alle alle, Common Guillemot Uria aalge and Brünnich’s Guillemot U. lomvia.

\section{Svalbard and Jan Mayen}

Svalbard is an archipelago of mountainous islands in the Arctic Ocean, located between latitudes $74^{\circ}$ and $81^{\circ} \mathrm{N}$ and longitudes $10^{\circ}$ and $35^{\circ} \mathrm{E}$. It covers a total terrestrial area of approximately $61,200 \mathrm{~km}^{2}$. Svalbard includes the small island of Bjørnøya (Bear Island), which is located roughly $240 \mathrm{~km}$ south of Spitsbergen and midway between mainland Norway and the main part of the archipelago. Bjørnøya is one of the few areas in the Atlantic Ocean where all the Atlantic auk species are found breeding.

Despite its extreme northern location, the region is one of the most accessible parts of the High Arctic. A branch of the North Atlantic Current transports relatively warm and high-salinity water northwards into the Barents Sea and along the western coast of Spitsbergen throughout the year. This water mass mixes with cold polar water, resulting in high marine production at fronts. The resulting huge biomass of pelagic invertebrates and fish forms the food base for large populations of marine birds and marine mammals (Mehlum and Bakken 1994, Hisdal 1998).

The isolated island of Jan Mayen is situated between the Greenland Sea and the Norwegian Sea $\left(71^{\circ} \mathrm{N}, 8^{\circ} 30^{\prime} \mathrm{W}\right), 1,000 \mathrm{~km}$ west of Norway, $500 \mathrm{~km}$ east of Greenland and $600 \mathrm{~km}$ north of Iceland. The island is 54 $\mathrm{km}$ long and 2,5 km to $17 \mathrm{~km}$ wide. Like Svalbard, Jan Mayen is situated in a highly biologically productive convergence zone of the southflowing East Greenland Current and the north-flowing North Atlantic Current, which strongly influences its fauna (Gabrielsen et al. 1997, Gabrielsen and Strøm 2004).

\section{The database}

Mehlum and Fjeld (1987) published the first seabird colony catalogue covering the Svalbard area. In 1989 a database was established in dBase format, and later a front-end program was developed named "COLONY" (Bakken 2000). After completing the material from Svalbard (579 colo- 
nies in total) the database was, in co-operation with Russian research institutions, extended to also include the Russian areas of the Barents Sea and the White Sea. The present version was completed in 1997, and all known colonies (1,547 in all) in the Barents Sea region (Norwegian and Russian sector) are currently registered in the database. In addition, more than 3,000 colony counts and more than 9,000 single counts of species are included (Bakken 2000). The Jan Mayen data was entered into the database in spring 2004. The database is regularly updated as new information is available.

"COLONY" is a database programme designed for the compilation and processing of data on seabird colonies. The database consists of five different tables: Colony description, total counts, counts in study plots, photo documentation and references. A total of 18 colony-breeding seabird species are registered in the database. The database allows easy storage and overview of information about the location of seabird colonies, their breeding species and the number of breeding pairs in various years. With minor programme changes, "COLONY" may be adapted to other sea areas and seabird species (Bakken 2000).

The colony database for the Barents Sea Region has been used for oil/seabirds impact assessments in the Barents Sea (e.g. Isaksen et al. 1998), identification of vulnerable areas in relation to oil spills (e.g. Moe et al. 1999, Systad et al. 2003) and for evaluation of the protected areas in Svalbard (Theisen and Brude 1998). Aggregated data from the database have also been used as basis for figures and maps presented in different magazines and books (e.g. Anker-Nilssen et al. 2000).

In 2004 an Internet version of the database was developed for local management agencies and research institutions in Norway and Russia. This online version allows easy search and downloading of data via Internet.

\section{Population sizes and number of colonies}

\section{Svalbard}

Eighteen species of seabirds breed in Svalbard (the Arctic Skua not included; Table 5). The most numerous species is probably the Little Auk (207 colonies), but fewer than 50\% of the colonies have been censused. About 900,000 breeding individuals are registered, but the actual number is certainly much higher. Most of the population breeds in colonies in the southwestern and northwestern parts of Spitsbergen, especially in Hornsund, Bellsund and the area around Magdalenafjorden. The second most numerous species is Brünnich's Guillemot, which is registered in 146 colonies. According to the database, the total population is about $1,370,000$ breeding individuals, an estimate which is probably relatively reliable. The Brünnich's Guillemot is found all over Svalbard except the easternmost areas. The largest colonies (several over 100,000 pairs) are 
situated on the southeastern part of Spitsbergen (Koval'skijfjella and Stellingfjellet), Hopen and Bjørnøya. More than $80 \%$ of the Svalbard population breeds within this "triangle". The Common Guillemot also breeds in Svalbard, with the main colony on Bjørnøya where it breeds mixed with Brünnich's Guillemot. The breeding population is between 100,000-150,000 pairs.

Table 5. Colonial seabirds breeding in Svalbard (based on Bakken 2000 and Strøm in press).

\begin{tabular}{lllll}
\hline Species & $\begin{array}{l}\text { No. of colonies } \\
\text { recorded in the } \\
\text { database }\end{array}$ & $\begin{array}{l}\text { No. of colonies } \\
\text { censused }\end{array}$ & $\begin{array}{l}\text { No. of breeding } \\
\text { ind. in the censu- } \\
\text { sed colonies }\end{array}$ & $\begin{array}{l}\text { Estimated total no. of } \\
\text { breeding pairs in } \\
\text { Svalbard }\end{array}$ \\
\hline Northern Fulmar & 129 & 92 & 163,017 & $500,000-1,000,000$ \\
Common Eider & 119 & 116 & 44,897 & 17,000 \\
King Eider & 7 & 7 & 182 & 500 \\
Common Gull & 1 & 1 & 2 & 500 \\
Herring Gull & 1 & 1 & 2 & $1-5$ \\
Lesser Black-backed Gull & 1 & 1 & 4 & $0-2$ \\
Great black-backed Gull & 25 & 24 & 104 & $50-150$ \\
Black-legged Kittiwake & 214 & 174 & 55,014 & 270,000 \\
Sabine's Gull & 2 & 2 & 13 & $1-10$ \\
Glaucous Gull & 224 & 163 & 8,421 & $4,000-10,000$ \\
Ivory Gull & 44 & 34 & 1,904 & $200-750$ \\
Arctic Tern & 80 & 78 & 8,715 & $<10,000$ \\
Common Guillemot & 23 & 23 & 74,383 & $100,000-150,000$ \\
Brünnich's Guillemot & 146 & 123 & $1,374,059$ & 850,000 \\
Razorbill & 4 & 3 & 103 & 100 \\
Black Guillemot & 202 & 141 & 9,204 & 20,000 \\
Little Auk & 207 & 104 & 896,523 & $>1,000,000$ \\
Atlantic Puffin & 107 & 79 & 8,375 & 10,000 \\
\hline
\end{tabular}

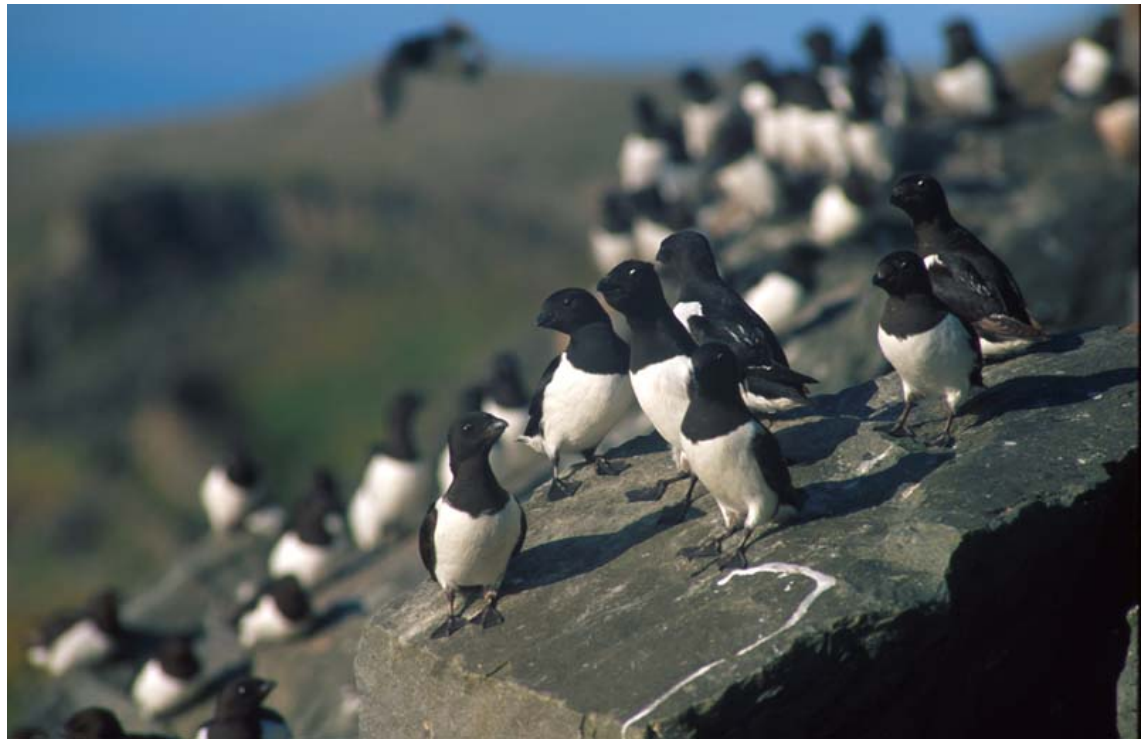

The Little Auk, here at the Alfredfjellet colony, is the most numerous bird species breeding in Svalbard. Most of the population breeds in colonies on the southwestern and northwestern parts of Spitsbergen. The total breeding population is estimated to be more than one million pairs. Photo: Hallvard Strøm, July 2002.

The Black Guillemot Cepphus grylle breeds all over Svalbard (202 colonies), but the total number of birds registered in the database (about 9,000 
individuals) is far too low. This is due to the lack of a suitable census method. Most of the Razorbills Alca torda breed on Bjørnøya, but the total population is only about 100 pairs. Svalbard is probably the northernmost breeding area for the Razorbill in the world. The Atlantic Puffin Fratercula arctica breeds in Svalbard in small numbers and a total of 107 colonies are registered. The number of breeding individuals registered is about 8,300, but this again is too low.

Another common species in Svalbard is the Black-legged Kittiwake Rissa tridactyla. This species is registered in 214 colonies and $>500,000$ breeding individuals are registered in the database. Few King Eiders Somateria spectabilis are registered as not all colonies have been included in the database. The Northern Fulmar Fulmarus glacialis is registered in 129 colonies and breeds almost all over Svalbard. The breeding population is somewhere between 100,000 and 1,000,000 breeding pairs. The Glaucous Gull Larus hyperboreus also breeds all over Svalbard (224 colonies) with the largest colony on Bjørnøya (about 4,000 breeding individuals in 1986). The Great Black-backed Gull Larus marinus breeds in small numbers along the western coast of Spitsbergen and at Bjørnøya (25 colonies).

The Sabine's Gull Larus sabini is only found breeding in one colony on the island Moffen ( $<5$ pairs) north of Spitsbergen. The colony at Moffen is the only known breeding colony in the Barents Sea, although single pairs have been found breeding elsewhere in Svalbard. The Ivory Gull Pagophila eburnea is registered in 44 colonies, but many of the records are old. In the database fewer than 2,000 breeding individuals are registered. By adding the numbers for all species in the database, we get an estimate of between 2,8 and 3,3 million pairs of seabirds breeding in the Svalbard area. 
Figure 5. Seabird colonies in Svalbard, where a total of 579 colonies are registered.

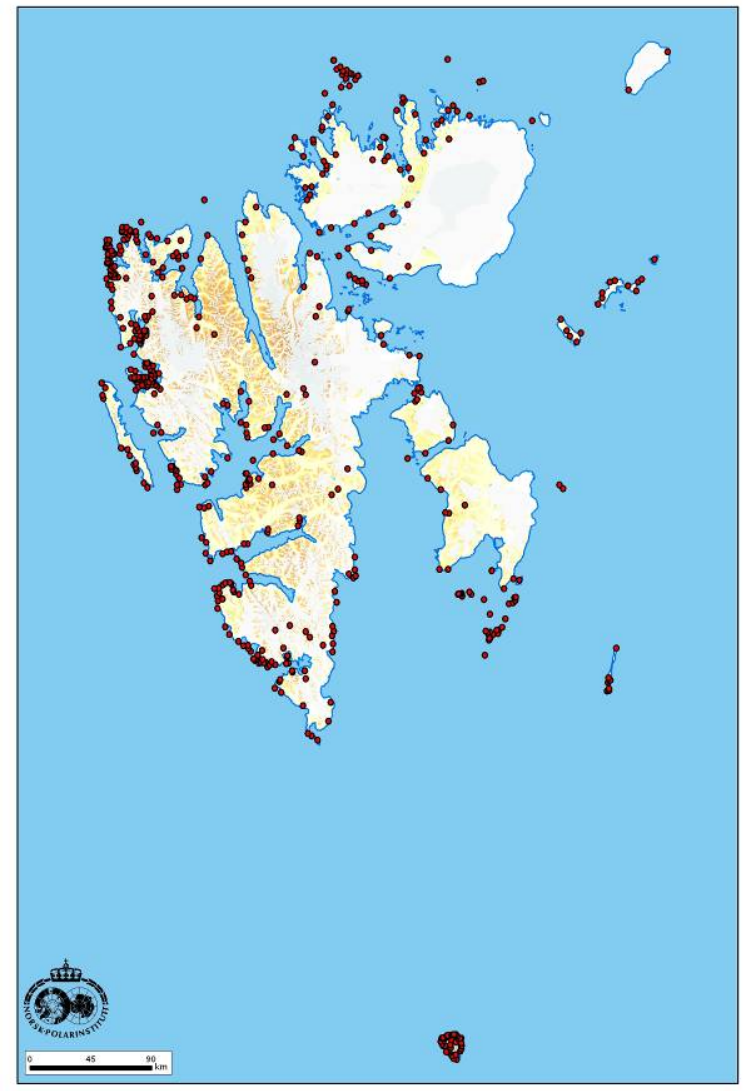

Jan Mayen

A total of 98 bird species have been recorded on Jan Mayen (van Franeker et al. 1998), of which 27 have been reported to breed on the island or were likely to do so in small numbers. The majority of the breeding species are marine or related to the marine environment. The four commonest seabirds are the Northern Fulmar, Black-legged Kittiwake, Brünnich's Guillemot, and Little Auk (van Franeker et al. 1998). A minimum of 22 colonies is known on Jan Mayen (Figure 6), but the actual number may be much higher. The island is not well surveyed and detailed information is lacking for many of the colonies. Based on both published and unpublished data an estimated 180,000-270,000 pairs of seabirds breed on Jan Mayen (Table 6). 


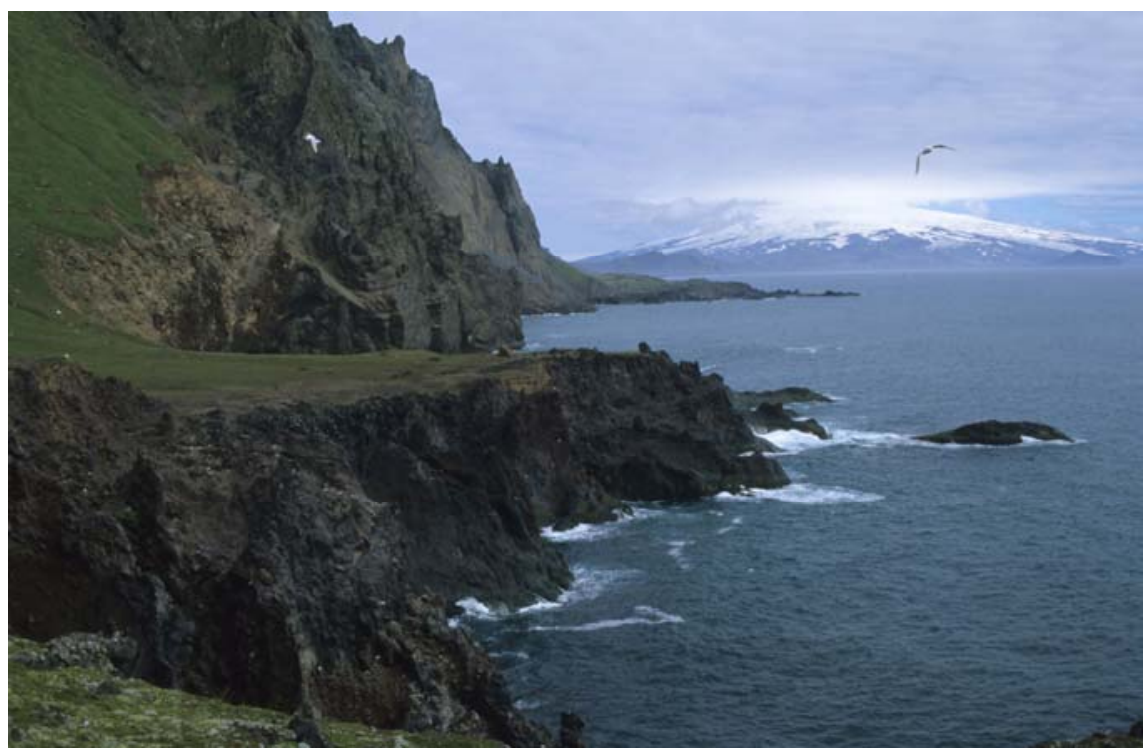

Jan Mayen supports important populations of seabirds. Here we see along a cliff at Schiertzegga, harbouring breeding Northern Fulmars. The old, impressive volcano Beerenberg, is in the background. Photo: Georg Bangjord, July 2004.

Table 6. Colonial seabirds breeding on Jan Mayen (total estimates based on van Franeker et al. 1998 and unpublished data in the archive of the Norwegian Polar Institute).

\begin{tabular}{lllll}
\hline Species & $\begin{array}{l}\text { No. of colonies } \\
\text { recorded in } \\
\text { the database }\end{array}$ & $\begin{array}{l}\text { No. of } \\
\text { colonies } \\
\text { censused }\end{array}$ & $\begin{array}{l}\text { No. of breeding } \\
\text { ind. in the censu- } \\
\text { sed colonies }\end{array}$ & $\begin{array}{l}\text { Estimated total no. } \\
\text { of breeding pairs } \\
\text { on Jan Mayen }\end{array}$ \\
\hline Northern Fulmar & 22 & 22 & 106,028 & 106,000 \\
Common Eider & 5 & 5 & 80 & 200 \\
Common Gull & 3 & 3 & 6 & $1-5$ \\
Herring Gull & 3 & 3 & 6 & $1-5$ \\
Lesser Black-backed Gull & 4 & 4 & 20 & $15-20$ \\
Great Black-backed Gull & 6 & 6 & 24 & $10-15$ \\
Black-legged Kittiwake & 15 & 15 & 8,795 & 9,300 \\
Glaucous Gull & 2 & - & - & 200 \\
Arctic Tern & 3 & 3 & 250 & $500-1000$ \\
Common Guillemot & 2 & 2 & 253 & $<1000$ \\
Brünnich's Guillemot & 13 & 13 & 104,527 & 50,000 \\
Razorbill & 2 & 2 & 21 & $100-200$ \\
Black Guillemot & - & - & - & $100-1000$ \\
Little Auk & 6 & - & - & $10,000-100,000$ \\
Atlantic Puffin & 6 & - & - & $1000-10,000$ \\
\hline
\end{tabular}


Figure 6. Seabird colonies on Jan Mayen based on data included in the colony database.

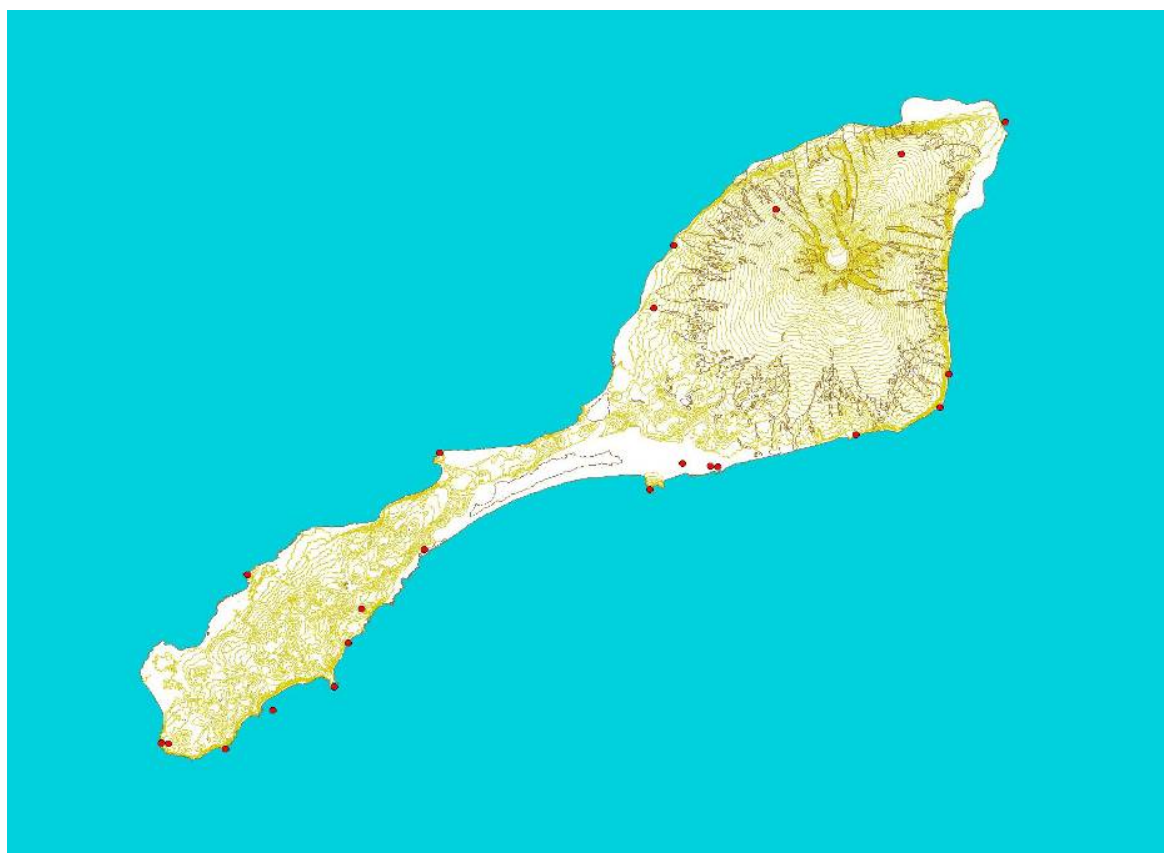

The monitoring programme and times series

A monitoring programme for Svalbard was initiated in 1988 (1986 on Bjørnøya) and at present (2005), seven species (Northern Fulmar, Common Eider, Great Skua, Glaucous Gull, Black-legged Kittiwake, Common Guillemot, Brünnich's Guillemot and Little Auk) are included in the programme. Monitoring of population development is carried out annually for all seven species except Little Auk. Data on survival, breeding success and chick diet are monitored on Bear Island for all species except Northern Fulmar; on Spitsbergen for Black-legged Kittiwake, Brünnich’s Guillemot and Little Auk. The species monitored, the number of colonies and the length of the data series are given in Table 6 and the monitoring sites are shown in Figure 7. There is no current seabird monitoring on Jan Mayen, but plans for this has been made (Gabrielsen and Strøm 2004). 
Table 7. Seabird species monitored in Svalbard.

\begin{tabular}{lllllll}
\hline Species & $\begin{array}{l}\text { No. of } \\
\text { colonies } \\
\text { currently } \\
\text { monitored }\end{array}$ & Start year & $\begin{array}{l}\text { Length of } \\
\text { series } \\
\text { (years) }\end{array}$ & $\begin{array}{l}\text { Adult } \\
\text { survival }\end{array}$ & $\begin{array}{l}\text { B*eeding } \\
\text { success** }\end{array}$ & Diet** $^{\star *}$ \\
\hline Northern Fulmar & 2 & 1988 & 18 & - & - & - \\
Common Eider & $1^{*}$ & 1980 & 25 & - & - & - \\
Glaucous Gull & 1 & 1997 & 9 & 9 & 9 & - \\
Black-legged Kittiwake & 10 & 1988 & 18 & 1 & 1 & 1 \\
Brünnich's Guillemot & 12 & 1987 & 19 & 18 & 18 & 18 \\
Common Guillemot & 1 & 1987 & 19 & 18 & 18 & 18 \\
Little Auk & 2 & 2004 & 2 & 1 & 1 & 2 \\
\hline
\end{tabular}

* Several islands in the Kongsfjorden area

** Number of years with data. Bjørnøya (Bear Island) only. On Spitsbergen monitoring of demographic parameters in 2005 (Black-legged Kittiwake, Brünnich's Guillemot and Little Auk)

Figure 8. Seabird monitoring sites on Svalbard (2005).

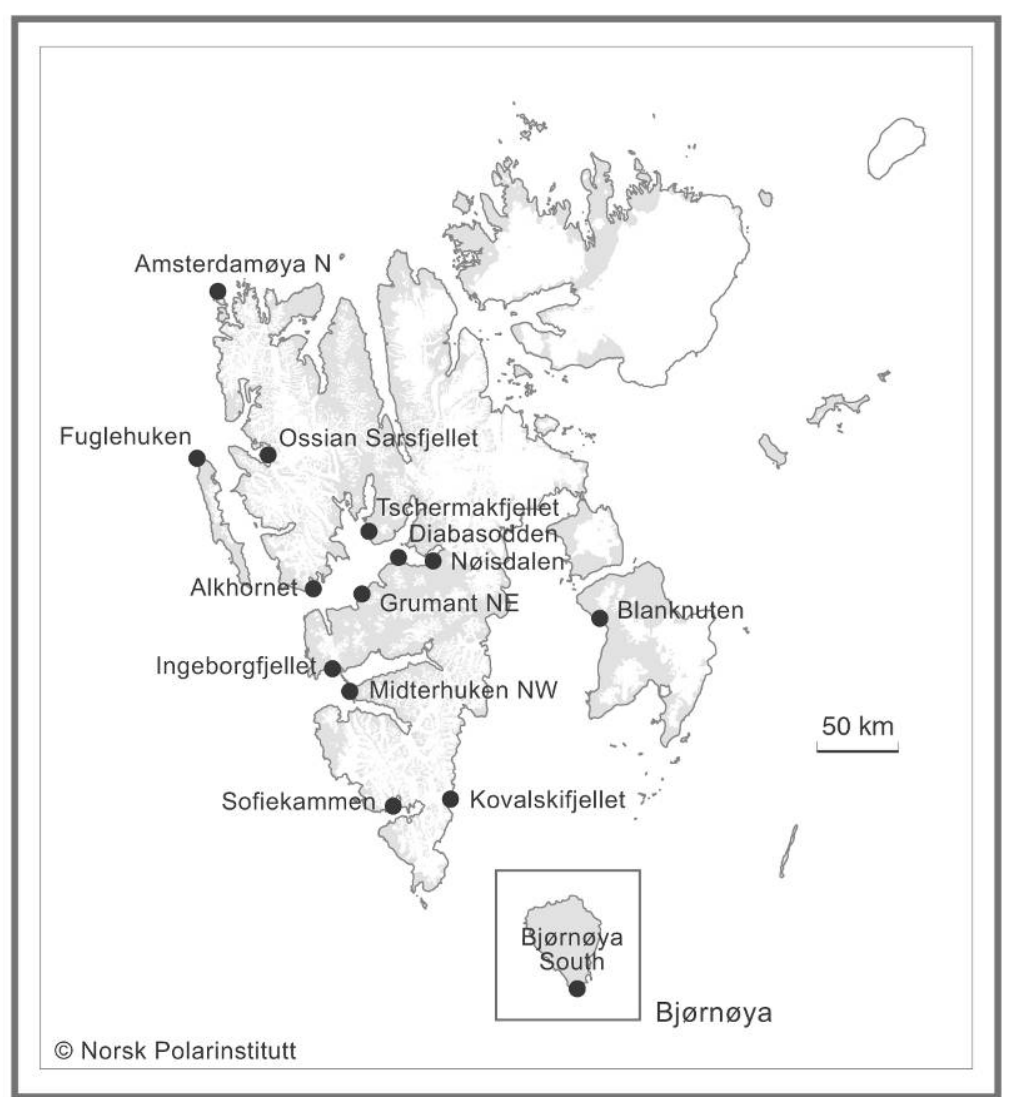

\section{Main gaps and concerns}

The most immediate concern is that, in order to keep the database operational, the information needs to be updated regularly. To improve the quality of the information, colonies should be surveyed at intervals of not longer than 10 years. A national programme for this is currently (2005) 
being implemented (SEAPOP - "Seabird Population Management and Petroleum Operations”).

SEAPOP is a national seabird mapping and monitoring programme organized to improve decision-making in the marine sector (AnkerNilssen et al. 2004). The vision of SEAPOP is to give the oil industry, environmental managers and other sectors the knowledge necessary to make decisions concerning environmental questions related to seabirds, petroleum operations or other activities in the coastal zone. If the programme is fully implemented, detailed and up-to-date information concerning the distribution, status and dynamics of Norwegian (including Svalbard) seabird populations will be generated through a coordination of the activities of the participating institutions. Special focus is put on process-oriented studies and monitoring to address both natural and manmade factors (Anker-Nilssen et al. 2004). The programme was started in 2004 (Barrett et al. 2005)

\section{Hallvard Strøm}




\section{Work of the project group}

The Nordic Seabird Colony Databases project group consists of members from Greenland, Iceland, Faroes, and Norway. As mentioned in the introduction for the first three countries their total area was included in the project work, while Svalbard and Jan Mayen were included from the Norwegian side.

The first preparations for the project were made with an application to the Nordic Council on 20 November 2001. The application was already accepted at the beginning of 2002, but final acceptance was not received until June 2002. At that time only Greenland, Iceland and Norway were identified as participants in the project, but questions were raised why Faroes were not also included. The initial project group gladly accepted this suggestion and by the beginning of September 2002 funding had been secured for the participation of the Faroes. The final composition of the project group and acceptance by the funding agencies therefore took the better part of the year 2002. The project was funded by two of the permanent working groups of the Nordic Council, the one on monitoring and data (NMD) and on nature, outdoor activities and cultural environment (NFK).

Only one meeting of the project group was included in the available funds, inevitably towards the beginning of the project. This meeting was held in Akureyri, N-Iceland, in 14-17 December 2002. However since most of the project members do also take part in the seabird expert group of CAFF of the Arctic Council, preliminary discussions took place at its eighth meeting in Anchorage, Alaska, in January 2002. At the Akureyri meeting the major lines were laid down for the project work ahead. Besides discussions on logistics seabird colony data were reviewed for each country, but most of the time was spent on the harmonized database format, the fields needed in the database, storage possibilities, graphic needs, and products. Other related issues included web-solutions for common databases, the database format as a potential template for the entire Arctic region, rules for common use and analyses of the data compiled, and future issues. Division of work also needed to be decided upon and a time schedule.

The formal work on the project was initiated with the Akureyri meeting in December 2002. Since then most of the work has been undertaken nationally and through correspondence. However, the members have continued to make use of other meeting opportunities within the seabird work of CAFF. The Arctic seabird expert group met in Tromsø, Norway, in January 2003, in the Faroes in February 2004, and in Aberdeen, Scotland, in February 2005. The development of the Nordic project was re- 
ported upon at these meetings. Those members of the Nordic Seabird Colony Databases project, who were present, also participated in "minimeetings" on the Nordic project.

The division of the project work was such that each of the national representatives was responsible for the project work within their respective countries. Two representatives participated for Greenland and Norway. From the latter one representative was responsible for the overall technical work on the database. The national databases available prior to the present project needed changes for integration into the format, which the project group agreed upon.

Prior to the project no seabird colony data had been computerized for Faroes and Jan Mayen. Efforts were started to computerize all available colony data, from published sources or otherwise available. Much needed additional field work was also begun in the Faroes registering Arctic Tern colonies. Some additional field work could also be carried out in Iceland, while work was also continued to compile published and other assessable materials. The previous seabird databases for Greenland, Iceland and Svalbard were updated to the new database format.

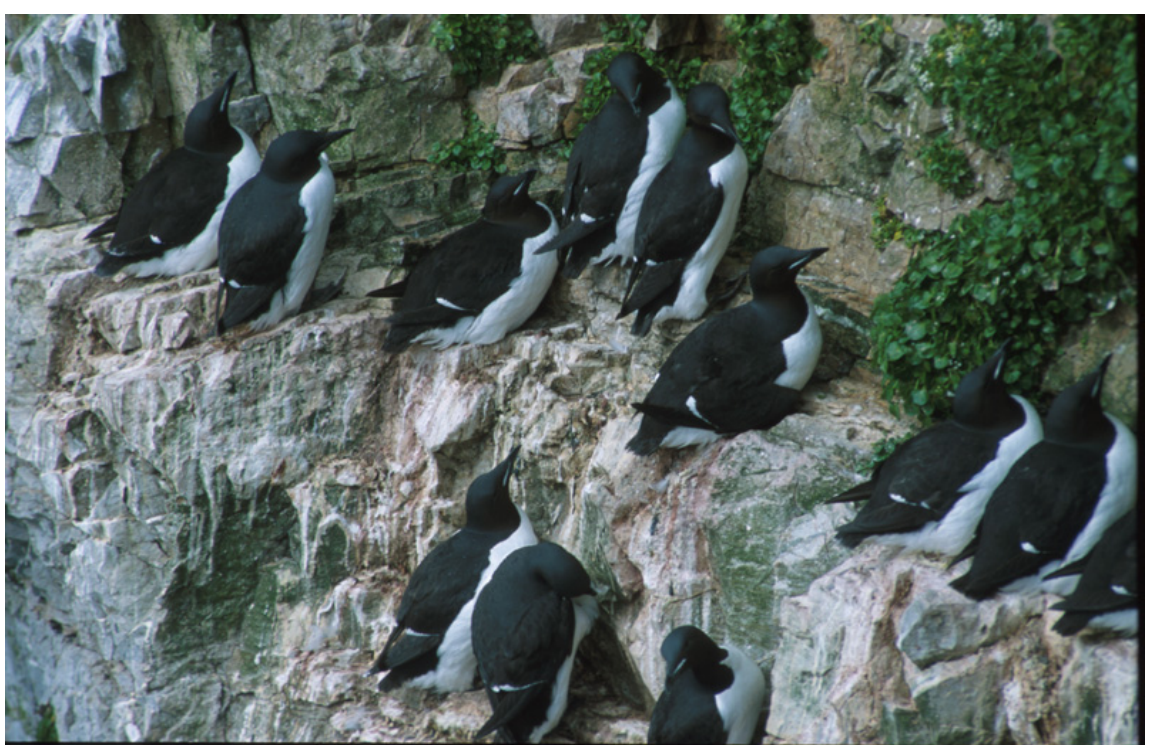

Vertical seabird cliffs are the typical colonies for seabirds in the minds of most people. The two guillemot species, Brünnich's Guillemot and Common Guillemot, form the core bird species on seabird cliffs. Here are Brünnich's Guillemots on a typical breeding ledge on Bear Island, Svalbard. Photo: Hallvard Strøm, June 2000.

The most complex part of the project related to development of the database software. This was the primary responsibility of Vidar Bakken, who as the work progressed involved the computer section of the Norwegian Polar Institute (Harvey Goodwin) in certain parts of the computing work.

The project leader (Aevar Petersen), besides being responsible for Iceland's contribution, also led the group's general work, kept contact with the Nordic groups which supported the project and oversaw the financial 
matters. During the project period five status reports were put together for the funding agencies. 



\section{Description of the database system}

Vidar Bakken and Harvey Goodwin

The database program itself can be downloaded free of charge from the web for the use by other seabird colony database managers. The link is $\mathrm{ftp} / / / \mathrm{ftp}$. npolar.no/Out/NordicDatabase/.

The colony database system is based upon the database Access (Microsoft Corporation) and the Geographical Information System (GIS) ArcGIS 9.0 (ESRI Iinc.). Colony data are administrated through the Access database which can be operated independently from the GIS-system. The colony database consists of three main tables: Colony description, colony survey and study plot. Tables containing references, observers and photo documentation are linked to the main tables (Figure 8).

Figure 8. Tables and links in the Nordic Seabird Colony Database program.

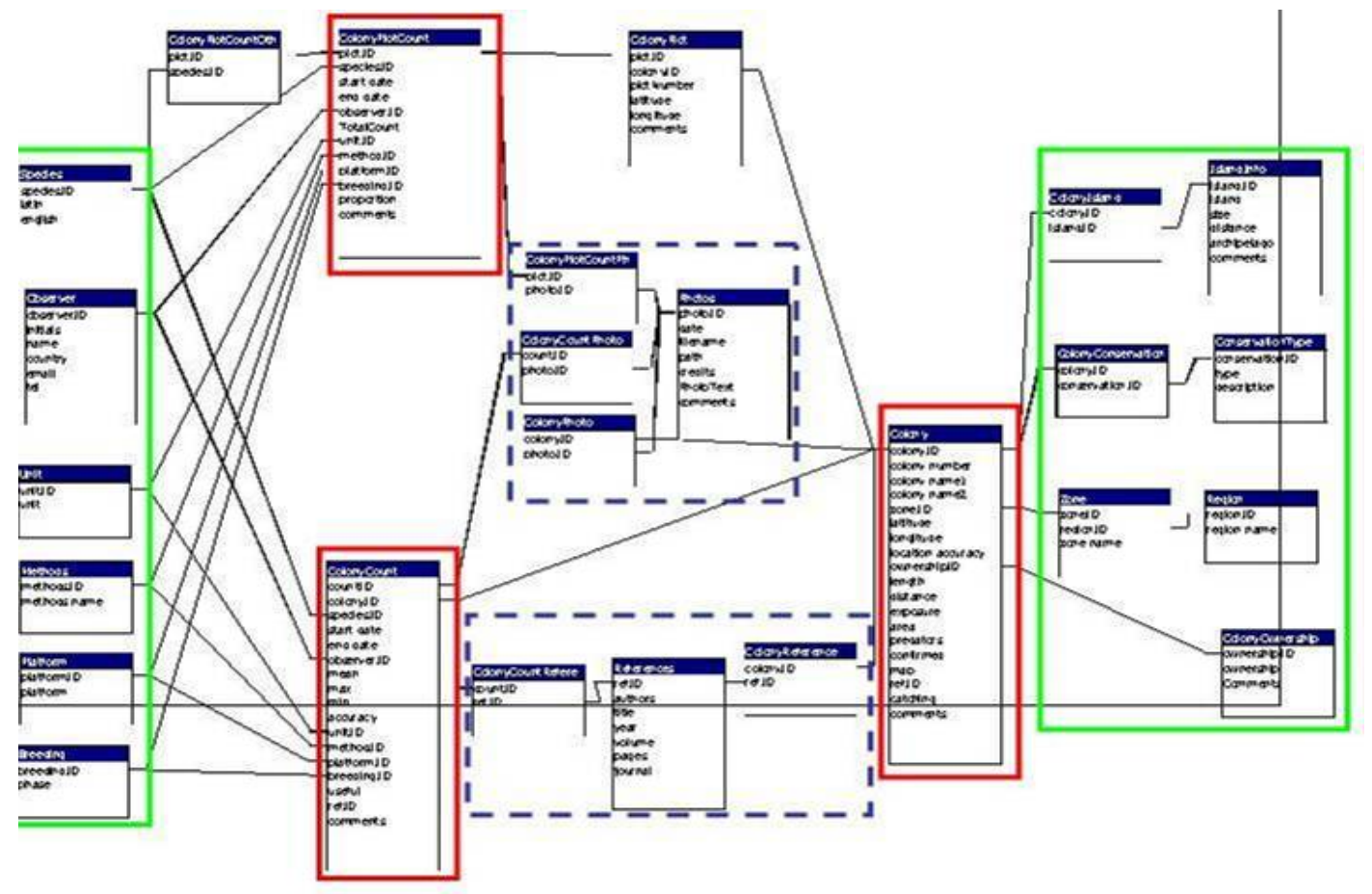


The following variables are defined:

C = Character, $\mathrm{N}=$ Numeric, $\mathrm{D}=$ Date, $\mathrm{B}=$ Boolean (true/false)

Table: Colony description

Colony number

C7 (Country ID, lat, number) (e.g.

GR80001)

Colony name_1

$\mathrm{C} 40$

Colony name_2

$\mathrm{C} 40$

Colony number

C7 (Country ID, lat, number)

(e.g. GR80001)

Region (Faroes, W-Greenland, E-Greenland, N-Greenland, Iceland, Svalbard, Jan Mayen) (N2)

Zone (N2)

Latitude (degrees, minutes, seconds, tenth of seconds)(WGS84)(N8)

Longitude (degrees, minutes, seconds, tenth of seconds)(WGS84)(N8)

Position accuracy $(>10 \mathrm{~km},<10 \mathrm{~km},<2 \mathrm{~km},<500 \mathrm{~m},<100 \mathrm{~m}$, GPSmeasured)

Conservation:

\section{IBA (B)}

Biosphere reserve (B)

Ramsar (B)

Emerald (B)

World Heritage area (B)

IUCN-categories (B)

National conservation status (No protection, nature reser-

ve, national park, other)(C20)

Ownership (private, government, claim, combined) (C15).

Island (B)

Island size (square meter) (N5)

Distance to mainland (N7)

Archipelago (B)

Length of colony (meters) (N7)

Distance to sea (minimum in meters) (N7)

Exposure of main colony (direction) (C10)

Area (of occupied habitat, flat area colonies in $\mathrm{m}^{2}$ ) (N7)

Introduced predators present

$$
\begin{array}{ll}
- & \text { Rat (B) } \\
- & \text { Mink (B) } \\
- & \text { Cat (B) } \\
- & \text { Rabbit (B) } \\
- & \text { Arctic Fox (B) }
\end{array}
$$

First year confirmed (N4) 
Breeding species (Information from total counts)

Reference map (best available map) (C20)

Literature reference (visible on screen) (link to literature table)

Photodocumentation (link to separate table)

Are the birds available for catching? (B)

Table: Colony survey

Colony number C7 (Country ID, lat, number) (e.g. GR80001)

Species (C20)

Date-start (D)

Date-end (D)

Time-start (N5)

Time-end (N5)

Observer (country ID + Initials)(Reference to another table (Name and country).

Best (mean) number (N7)

Maximum number (N7)

Minimum number (N7)

Accuracy (exactly, rough estimate) (C10)

Unit (pair, individual, unknown, apparently occupied nest, nest, adult male, unknown but probable pairs, unknown but probably individuals)

Method (direct count, from photographs, extrapolated, combination, unknown) (C20)

Platform (land, boat, helicopter, airplane, combination, unknown) (C20)

Breeding phase (pre-laying period, eggs only, hatching period, chicks only, unknown, but breeding, not breeding season) (C20)

Useful as numbers present during survey (B)

Photograph reference (C20)

Literature reference (link to the reference table)

Comments (C)

Table: Study plot

Colony number C7 (Country ID, lat, number) (e.g. GR80001)

Latitude (degrees, minutes, seconds, tenth of seconds)(WGS84) (N8)

Longitude (degrees, minutes, seconds, tenth of seconds)(WGS84) (N8)

Species (C30)

Plot number (C4)

Method (C20)

Platform (C20)

All single counts on different days to be registered:

Numbers (N7)

Date (D) 
Phase (pre-laying period, eggs only, hatching period, chicks only, unknown) (C20)

Unit (pair, individual, apparently occupied nest, nest, adult male) (C20)

Proportion of different species (N3)

Other species (C30)

Photo reference (C20)

Observers (link to observer table)

One/two photographs of the plot.

Comments (C)

Table: Reference table

Authors (C30)

Title (C30)

Year (N4)

Volume (N3)

Pages (C10)

Archive reference (C20)

Table: Observers

Initials (Country+Initials) (C6)

Name (C30)

Table: Photo documentation

Colony number (C7) (Country ID, lat, number) (e.g. GR80001)

Year (N4)

To administrate the Access database a set of forms are shown. Some examples are shown below (Figure 9). 
Figure 9. Examples of forms from the Access database.

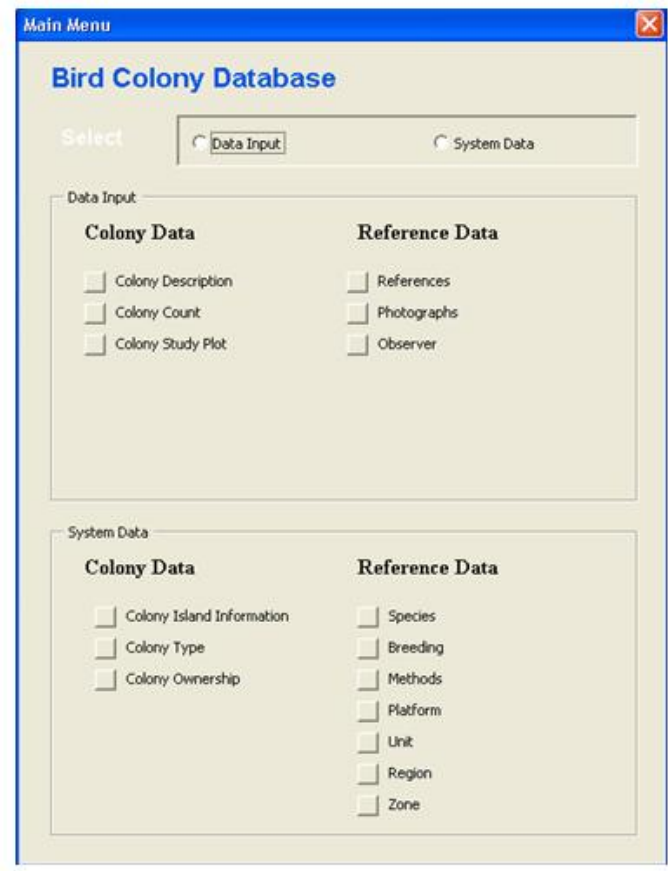

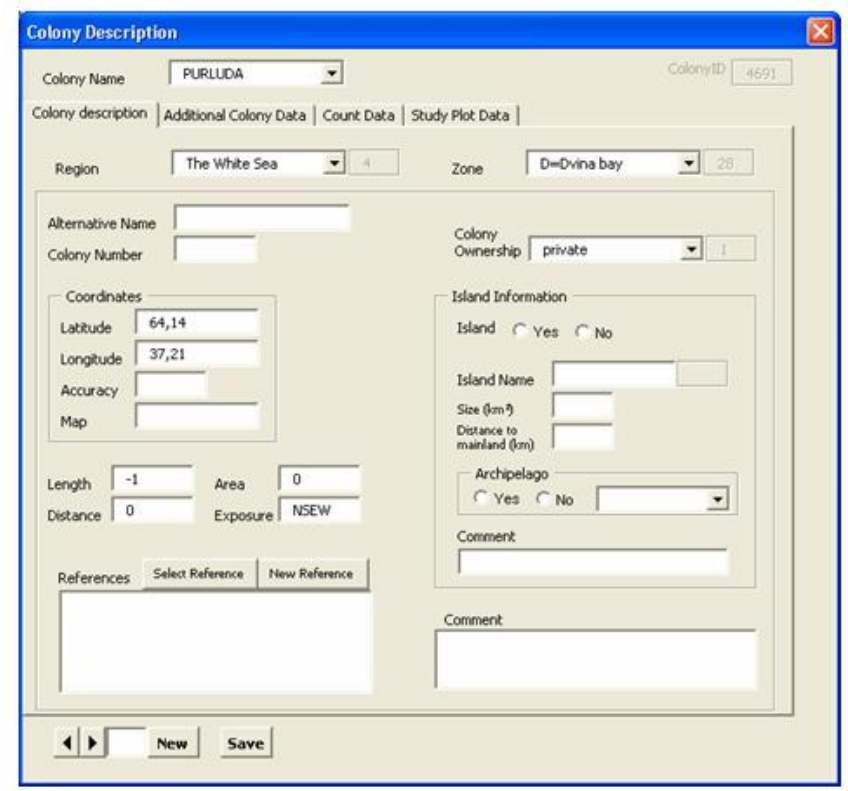



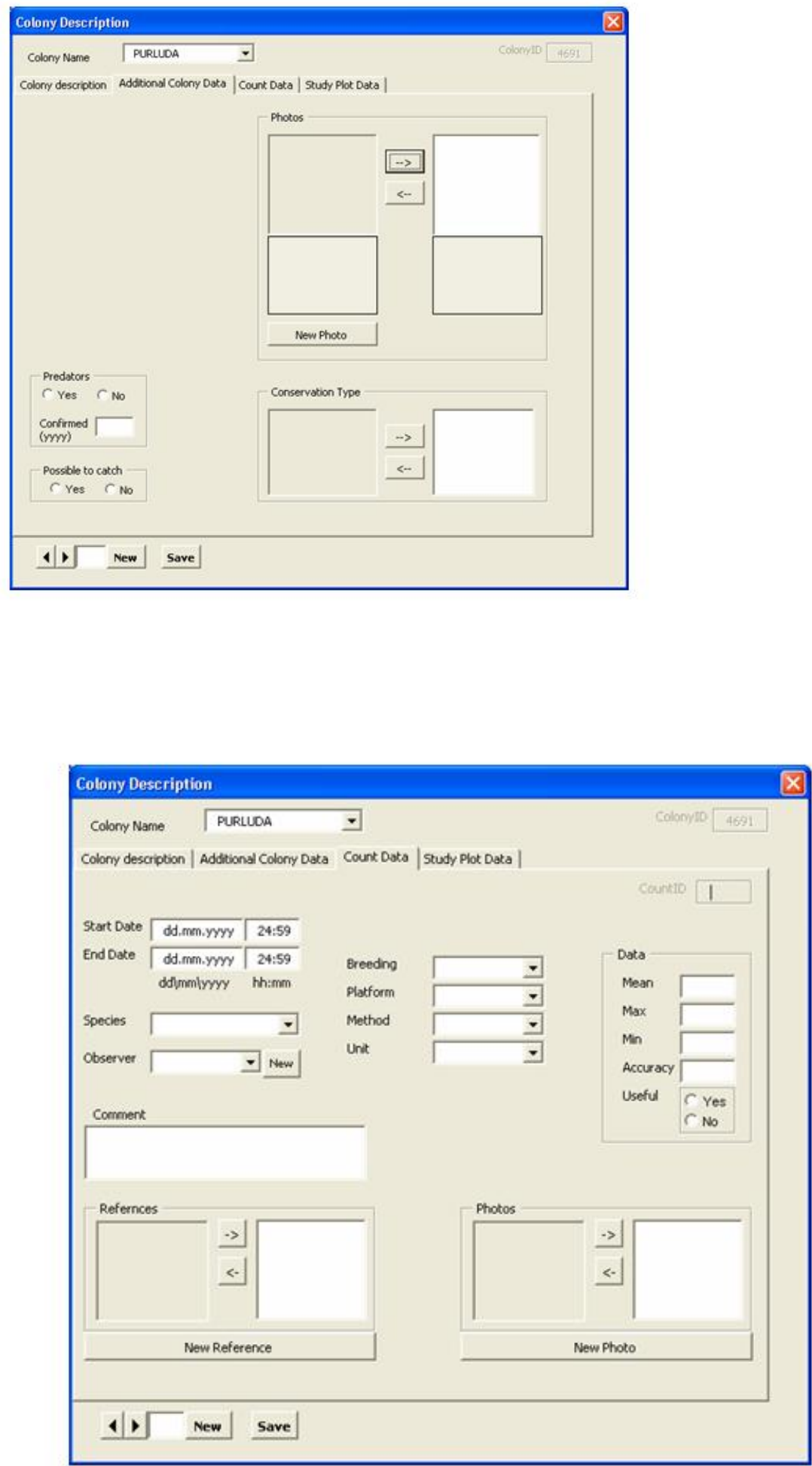


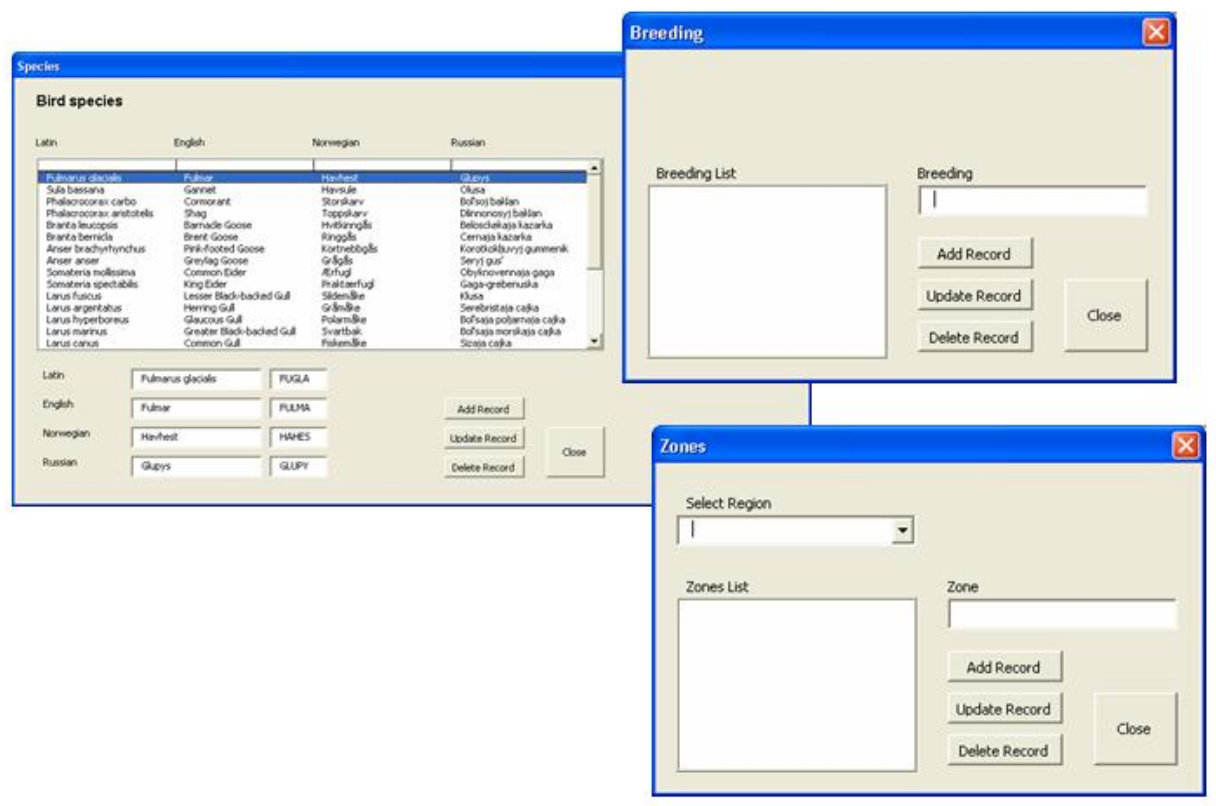

The Access database can be easily imported into the ArcGIS-system where the colonies may be visualized on maps. The system has extensive possibilities for visualization and analysis of the colony data. 



\section{The use of seabird colony databases}

David Boertmann and Anders Mosbech

\section{Introduction}

Seabird breeding colonies (seabird colonies, colonies) are important elements in nature. They contribute significantly to the local biodiversity, both directly and indirectly (by attracting predators, scavengers and by creating habitats for many other living organisms). They play a major ecological role as vectors of nutrients and carbon from the sea to terrestrial habitats. And in many regions they contribute to human existence by providing resources to local communities and by giving opportunities to recreational activities such as tourism. However, the large concentrations of breeding birds (often significant fractions of the total populations) gathered in very localised sites, are particularly vulnerable to human induced influences, such as disturbance, habitat alteration, fisheries and oil pollution. Therefore careful management of human activities, which can impact the seabird colonies, is necessary to protect them. Readily available and up to date information on the colonies is in this process crucial, and a database with seabird breeding colony information will be a most efficient tool in this respect. This is or should be an integral part of the conservation policies of the Nordic countries.

The purpose of a seabird colony database is primarily to keep updated information readily accessible, making it available for different purposes. Database design and contents may vary according to the specific use, although the information may be used for many different tasks, of which some of the more important ones will be described here. The Nordic seabird colony databases primarily contain data on species and numbers of birds or pairs, obtained during survey work. More specific information on e.g. reproductive performance of seabirds requires specifically designed databases. These can, however, be combined with the database on numbers as a separate module. A seabird colony database gives easy access to the survey information e.g. when analysing for population trends. Combined with a geographical information system (GIS) overviews of distribution and size of the colonies are also readily generated. 


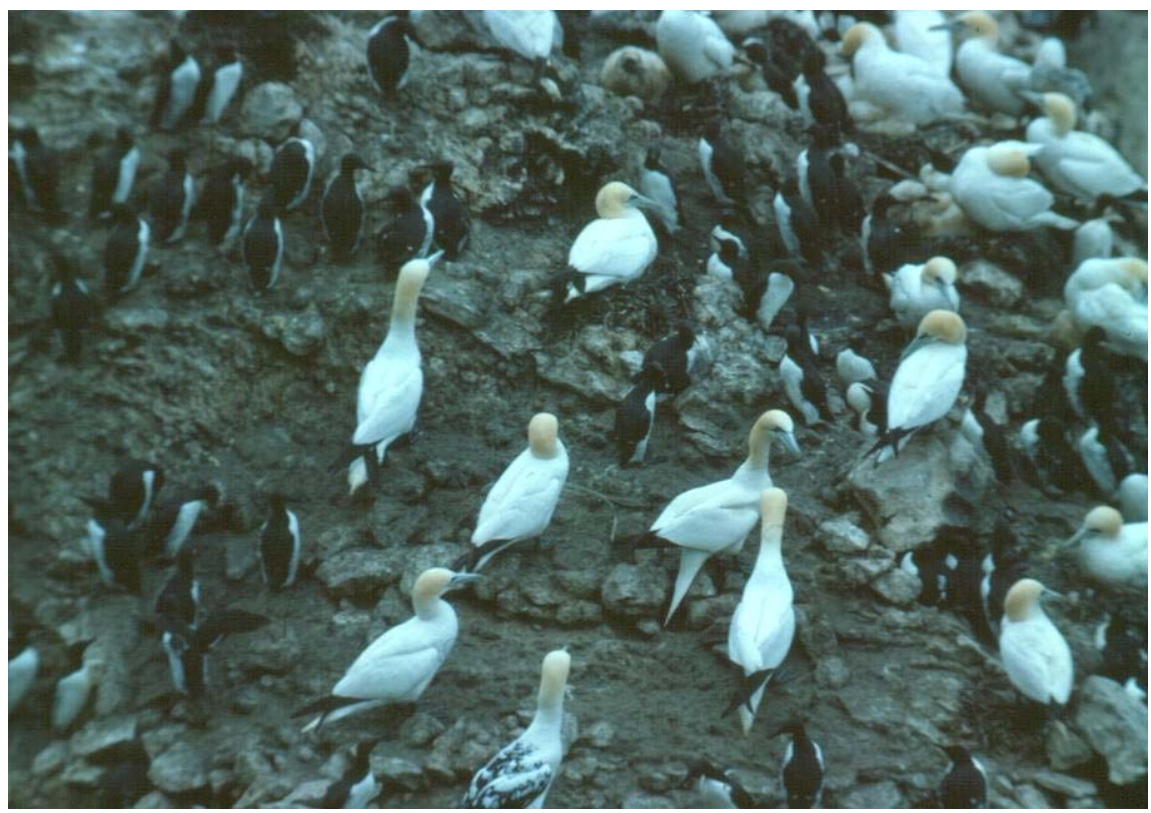

Top of stacks are sometimes shared by Gannets, which is the largest of the Arctic seabirds, and Common Guillemots. From Stóri Karlinn, Langanes, Northeast-Iceland. Photo: Aevar Petersen, 14.7.1984.

\section{Local planning and conservation}

A colony database is a valuable tool for local authorities considering nature conservation interests during planning of coastal zone use, as e.g. localizing and designating areas of high conservation interests. The Greenland colony database was, among others, developed as a tool for regulation of oil exploration activities along the West Greenland coast in order to mitigate and minimise impacts. It is well known that seabirds are particularly sensitive to oil spills which may occur during incidental blowouts or tanker wrecks. Daily activities like helicopter traffic may impact breeding seabirds, and a database may be used for designating the least disturbing flight routes.

The Greenland colony database is also an integral part of another planning tool: Oil spill sensitivity maps. In year 2000, an atlas covering the West Greenland coast from $62^{\circ} \mathrm{N}$ to $68^{\circ} \mathrm{N}$ was issued. This was in 2004 followed up and extended with two more atlases covering $60^{\circ} \mathrm{N}$ to $62^{\circ} \mathrm{N}$ and $68^{\circ} \mathrm{N}$ to $72^{\circ} \mathrm{N}$, and the result is now a sensitivity map covering the entire West Greenland coast as far north as $72^{\circ} \mathrm{N}$ (Mosbech et al. 2000, 2004a, 2004b). The purpose of these atlases is to facilitate oil spill response activities and to prioritize between different coasts according to their overall sensitivity to oil spills including coastlines with seabird breeding colonies.

Visiting large seabird breeding colonies may be an impressive experience. There is an interest in most countries for using colonies as tourist attractions and the goal for excursions. Tourist agencies and tour operators may use a seabird colony database for identification of colony sites 
and for planning excursion. Photographs of the seabird colonies, intended as an integral part of such a database, would facilitate this process.

\section{Environmental Impact Assessment}

Seabird colony database can also be developed for preliminary environmental impact assessment of offshore oil exploration. This was, for instance, put on the political agenda in Greenland in the early 1990s. The database facilitated a data-gap analysis, which subsequently was followed up by field surveys covering regions from where data on breeding seabirds was largely missing, out-dated, and where oil spills from future licence areas were likely to make an impact (Boertmann et al. 1996).

In case of oil spills hitting coasts with seabird colonies, pre-spill information on seabird populations will be readily accessible from a database, particularly if surveys have been carried out with regular intervals, i.e. where monitoring programmes have been carried out.

\section{Monitoring}

Monitoring programmes may be planned and designed based on the information in a seabird colony database. Single colonies can be selected for very local programmes or a suite of colonies can be identified for regional or national programmes. However, monitoring results can either be part of or kept as a separate module depending on the amount of available information. See e.g. Nettleship (1997) for a description of the Canadian seabird monitoring programmes, and Anker-Nilssen et al. (1996) for an assessment of monitoring programmes in Norway. Seabird colony monitoring programmes should be an integral part of oil spill preparedness, and information from such programmes may also contribute to many other management decisions, ecological research projects, etc. 


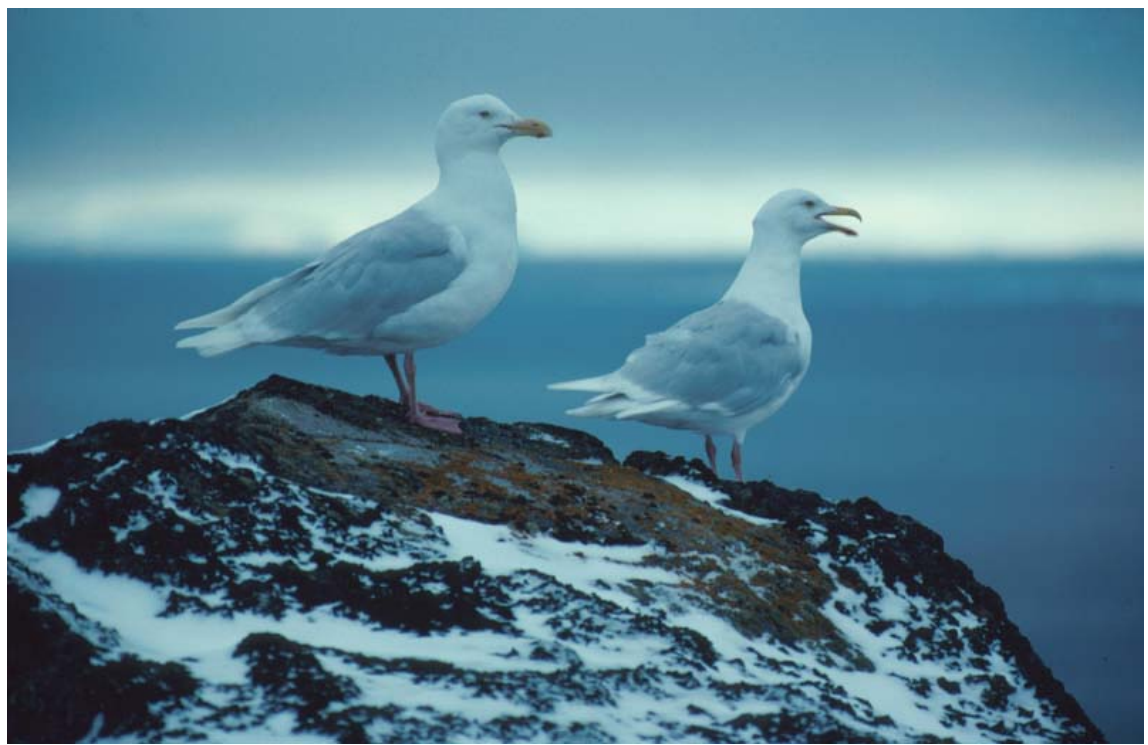

A pair of Glaucous Gulls (the little smaller female left) at Bear Island, Svalbard. Glaucous Gulls are important predators, and breed numerously in most parts of the Nordic Arctic. Photo: Hallvard Strøm, August 1992.

\section{Research and education}

The compilation of data from all seabird colonies within a large region, in a common format, as has been done within the Nordic Seabird Colony Databases project facilitates research in many ways. Differences and similarities across wide ecological and climatic regimes can be analysed and compared. Databases with long time series of colony surveys may contribute to analysis of trends in population size in relation to long term environmental changes, such as climate (e.g. Montevecchi and Myers 1997, Thompson and Ollason 2001). However, it is difficult to relate changes in breeding numbers to variability in environmental factors e.g. as food availability, because of the time lag in and buffer effect of responses in breeding numbers of many seabird species. In such cases a time series of behaviour or reproductive parameters at the colonies will be important to study (Monaghan 1996, Furness and Camphuysen 1997). A seabird colony database may be used for selecting sites for such studies, and seabirds are nonetheless long-term indicators of environmental changes, be that changes in feeding conditions in the marine ecosystem or due to climate change.

Regional estimates of breeding seabird numbers can be drawn from colony databases, and used for e.g. estimating energy and carbon fluxes among seabirds in large regions like the Barents Sea (Mehlum and Gabrielsen 1995). Lastly, information on seabird colonies from harmonized databases is an important tool in education, both formal through schools and informal of the general public and tourists. 


\section{Template for Arctic seabird colony databases}

Hallvard Strøm and Aevar Petersen

The idea to establish a harmonized database format for seabird colonies in Faroes, Greenland, Iceland, Jan Mayen, and Svalbard is partly a product of, and has strong links to, the work of the Circumpolar Seabird Group (CBird), an expert group under the program for Conservation of Arctic Flora and Fauna (CAFF), one of the permanent working groups of the Arctic Council. The CBird group, which was established in 1993, has had the subject of harmonizing seabird colony databases at the circumpolar level on its agenda. That effort has, among others, resulted in a joint circumpolar colony database for the two murre species (Common Murre and Thick-billed Murre). This database has been used to publish a series of maps, posters, reports, and scientific papers (e.g. CAFF 2000, CAFF 2001 (p. 92), Petersen and Bakken 2004 (p. 4 \& 10)).

The purpose of a seabird colony database is primarily to maintain an overview of seabird colony resources and information on numbers, trends, conservation status of colonies, distribution, etc., making these data available for different purposes. The compilation of data from seabird colonies within a large region in a common format, as has been done within the Nordic Seabird Colony Databases project, facilitates research and management in many ways. The tasks mentioned in Chapter 10 can easily be viewed in a circumpolar context, and the Nordic Seabird Colony Databases project can thus been seen as a potential template for seabird colony databases in the Arctic countries in general.

Over 60 seabird species breed in the Arctic and most of them are shared between two or more of the Arctic countries. These countries may share common populations and threats in marine and coastal ecosystems on which seabirds depend for their survival. Of the over 60 seabird species some 16 are only found breeding in the Arctic. For most of the species the Arctic countries share seabird species with countries in the Temperate regions towards the south. Consequently, there is a joint and shared responsibility for the conservation of Arctic seabirds both within and outside the Arctic. Seabird Colony Databases are important instruments for managing seabird populations. 


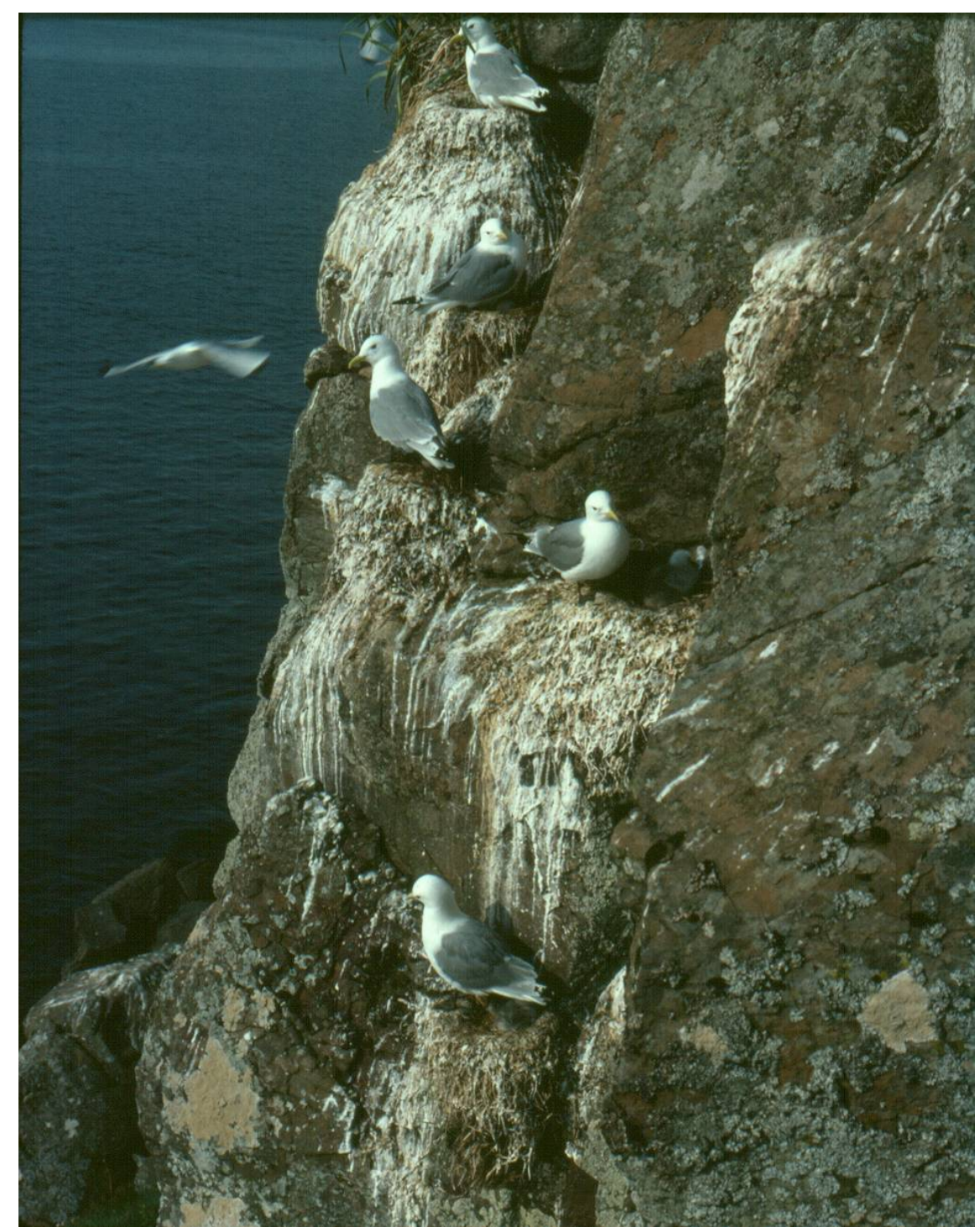

The Black-legged Kittiwake is among the most widespread seabird species nesting in the Northern Hemisphere. It is also one of the best monitored species. The small colony on Flatey island, West-Iceland, where this picture was taken, has been monitored since it was formed, in 1975. Photo: Aevar Petersen, 12.7.1980.

As was the case for some of the Nordic countries, several of the Arctic countries already have well established databases for both scientific and management purposes. Therefore, it may be unrealistic to expect all the eight Arctic countries to change to the same database platform, as their structure might be linked to specific national programs or tasks. However, by agreeing to a common set of criteria for describing seabird breeding colonies, population numbers and other database components, a great step forward is taken in facilitating a circumpolar approach to many scientific, conservation and management issues. During the Nordic database project four of the eight Arctic countries agreed to a standardized format, while the national needs of each country were also taken into account. It is likely that the Nordic database format covers most of the 
needs of the other three Arctic countries, which were not party to the Nordic project, although some minor changes and additions may turn out to be necessary. The idea for a circumpolar seabird database format was discussed at the meeting of the CBird group in Aberdeen, Scotland, in March 2005. The general idea was very well received, as both Canada and Alaska (for USA) have databases which need updating and the Nordic Seabird Colony Databases format will be a very good solution. It appears that the middle part of Russia is not covered by neither of the two current Russian databases (for western Russia and for eastern Russia), but this needs to be further explored.

An additional advantage of the Nordic project concerns the development of new software, which makes use of the most recent software and GIS technology. This may proof to be most helpful for other Arctic countries, if their current software has become of age. 



\section{Future issues and Recommendations}

On fulfilment of the present project it is logical to reflect on the future. The report contains examples of the use of harmonized seabird colony databases and how this may be expanded to seabird databases in other Arctic countries. A number of relevant issues are not included in the current exercise, but can be looked upon as possible next phases of the present project.

Each country will continue to be responsible for maintaining their seabird colony database, updating this, correcting mistakes, adding supporting details which may be lacking on individual colonies, e.g. habitat type, spread of colony, conservation status of the colony land, land ownership, etc. Besides many national uses in research, conservation and management, a harmonized seabird colony database makes it possible to undertake different common analyses on the data presently available in the participating countries over larger regions than hitherto possible, but many different kinds of analyses are feasible.

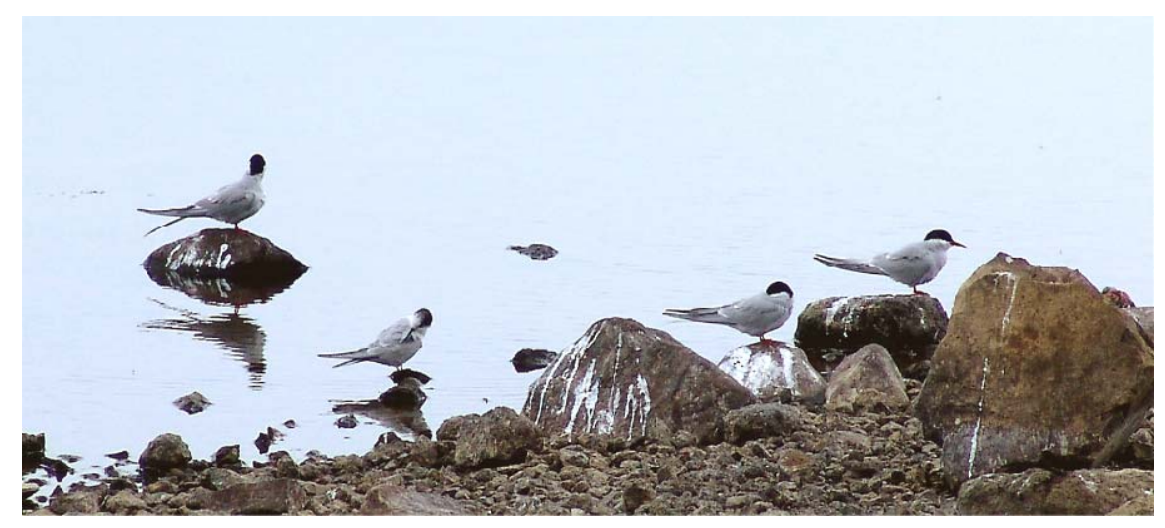

The Arctic Tern is one of the most renowned travellers of the bird world, nesting in the Northern Hemipshere and wintering in the Antarctic. The picture shows three adult birds resting on the shore on Sandoy in the Faroe Islands, together with a one-year old bird (with white forehead). Photo: Bergur Olsen, 8.8.2004.

A product example includes an overall N-Atlantic Seabird Colony Catalogue, which would include a general overview of the seabird species, a graphic presentation of the whereabouts of the colonies, and a current status of the seabird populations. This exercise may contain a gap analysis of the available data, such as how well each country has been covered as regards the distribution of seabird colonies and population sizes. 
Other examples would be scientific assessments of individual species, or group of species, including details of the colonies, colony size, trend data (if available), etc.

The seabird colony databases are designed to include information on the conservation status of individual colonies. Such an analysis may give a nice overview of how well seabird colonies are protected in the different countries.

Furthermore, the databases are designed to include information on the habitat and under which circumstances colonies are situated. There may be certain local differences in colony habitats and types, both between and within species. Pooling data from all countries makes such analyses feasible.

Conversion factors, i.e. correction factors which allows, for instance, for converting numbers of birds at colonies to numbers of pairs, continues to be an important issue in the methodologies used to estimate seabird numbers and how well data from different countries and workers, are comparable. Various methods can and have to be applied when censusing seabirds. These depend, inter alia on the species, the colony terrain, purpose of the census work, and the extent of the coverage. Development of a manual of methodologies and conversion factors recommended could be very helpful to further harmonize the data, which will be collected in the future.

Norway, together with Russia, has been developing a web-based portal for assessing of a common Norwegian-Russian Seabird Colony Database. This is planned for inputting data, making common analyses, use in management questions, etc. Furthering of that work to other countries is considered to be helpful.

A number of other data is collected on seabirds at colonies. This includes breeding success, food, survival figures, etc. A possible future development linked to the present database program, includes modules which would hold such data and allow different sophisticated analyses. These modules could be developed in connection with seabird work at the circumpolar level within CAFF. This could also be important contributions to the Circumpolar Biodiversity Monitoring Program, which is being developed by CAFF (see Petersen, Zöckler and Gunnarsdóttir 2004). 


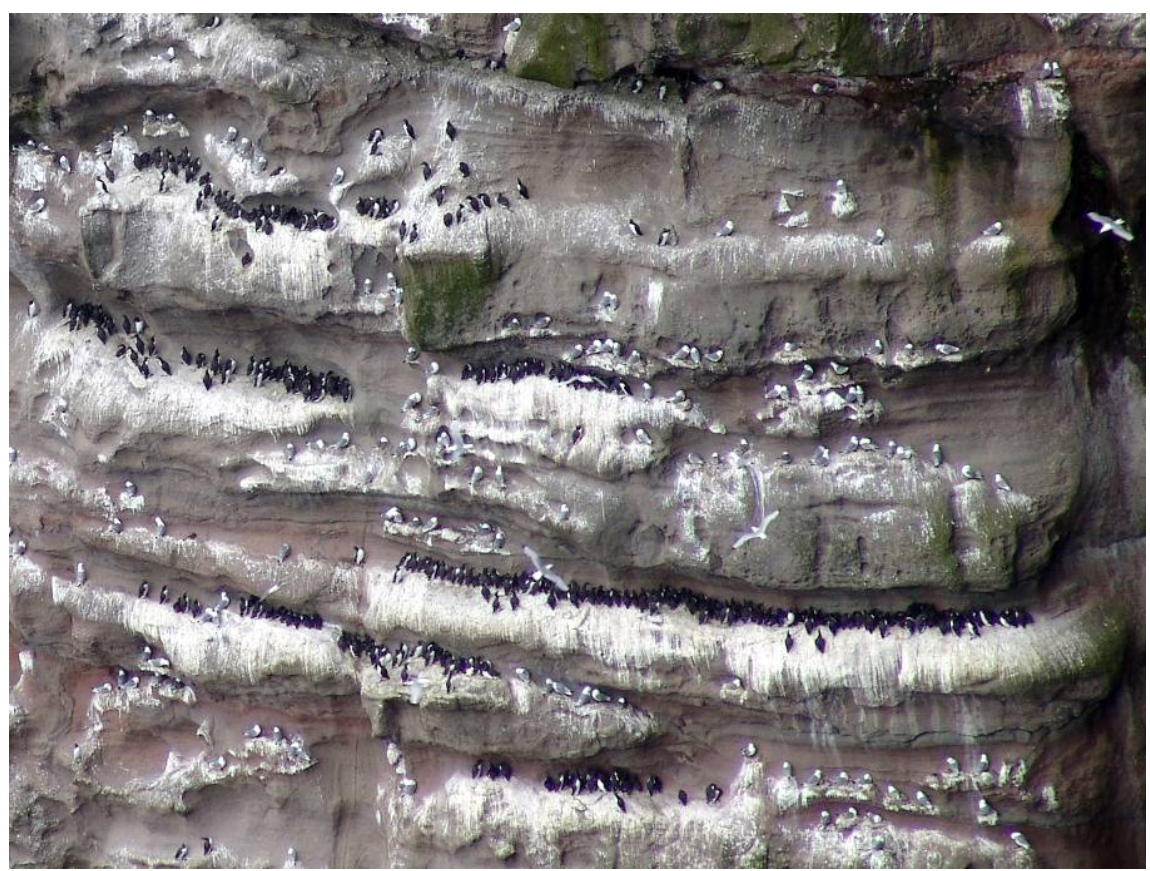

A long-term study plot including Common Guillemots and Black-legged Kittiwakes at Høvdin, Skúvoy island, Faroes. Photo: Bergur Olsen, 10.7.2004.

It is clear that the current databases are incomplete in many but variable ways. Large regions of the participating countries are still uncensused, such in Greenland, Jan Mayen and Iceland. Certain amount of already recorded data has still to be compiled from observers as well as entered into the national databases. The current overview of the distribution of colonies, let alone colony size, is at best partial for most species, and only for a handful of species we can say there is a complete overview of the whereabouts of colonies and the population size in the participating countries. The future emphasis must therefore be on intensifying fieldwork to localize colonies and census for size. The country reports (Chapter 7) gives some indications of the most imminent needs in each of the countries.

Lastly, the present database work could be important in contributing to a general scientific and authoritative work on Atlantic seabirds. As an example "The Atlantic Alcidae“, published two decades ago (Nettleship and Birkhead 1985), has been an important reference work for seabird biologists. Since then much new data has been collected on various aspects of auk biology, including colony and population data, making a new publication well worthwhile. 



\section{References}

\section{General}

CAFF 2000. Arctic Seabird Colonies and Fishing Areas. A poster.

CAFF 2001. Arctic Flora and Fauna. Status and Conservation, Edita, Helsinki. $272 \mathrm{pp}$.

Nettleship, D.N. \& T.R. Birkhead (eds) 1985. The Atlantic Alcidae (The evolution, distribution and biology of the auks inhabiting the Atlantic Ocean and adjacent water areas). Acad. Press, London, etc. $\mathrm{xx}+574$ pp.

Nordic Council of Ministers 1999. Nordic Action Plan to Protect the Natural Environment and Cultural Heritage of the Arctic - Greenland, Iceland and Svalbard. Nord 1999:29. 97 pp.

Petersen, A. \& V. Bakken 2004. Distribution of murres outside the breeding season "Circumpolar Murre Banding Program”. North Atlantic Region. CAFF Technical report no. 13. 22 pp. Petersen, A., C. Zöckler \& M.V. Gunnarsdóttir 2004. Circumpolar Biodiversity Monitoring Program. Framework Document. CAFF CBMP Report No. 1.40 pp.

\section{Faroes}

Bayes, J. C., M.J. Dawson, A. Holm Joensen \& G.R. Pots 1961. The distribution and numbers of the Great Skua (Stercorarius s. skua Brünn.) breeding in the Faeroes in 1961. Dansk Orn. Foren. Tidsskr. 58: 36-41.

Bengtson, S-A. \& D. Bloch 2003. The Arctic Skua Stercorarius parasiticus on the Faeroe Islands: abundance and plumage polymorphism. Dansk Orn. Foren. Tidsskr. 97: 210-220.

Bloch, D. \& S. Sørensen 1984.

Checklist of Faroese Birds. Føroya

Skúlabókagrunnur, Tórshavn. 84 pp

BirdLife International 2004. Birds in Europe: population estimates, trends and conservation status. Cambridge, UK. BirdLife International. (BirdLife Conservation Series No. 12).

Dyck, J. \& H. Meltofte 1973. Lomvieoptællingen på Færøerne 1972. Report issued by Dansk ornithologisk Forening (Copenhagen), The Fisheries Laboratory (Tórshavn) and Institute of Comparative Anatomy (University of Copenhagen). 97 pp.

Dyck, J. \& H. Meltofte 1975. The Guillemot Uria aalge population of the Faeroes 1972. Dansk Orn. Foren. Tidsskr. 69: 55-64.

Ferdinand, L. 1974. Studies of the birdlife in the Faeroes. Dansk Orn. Foren. Tidsskr. 41: 1-37. (Danish, Engl. summ.)

Grimmett, R.F A. \& T A. Jones 1989. Important bird areas in Europe. International Council for Bird Preservation, Technical Publ. No. 9.

Harris, M. P. 1984. The Puffin. T \& A.D. Poyser, Calton. 224 pp. Jensen, J-K., D. Bloch \& B. Olsen 2004. List of Birds seen in the Faroe Islands. Føroya Náttúrugripasavn, Tórshavn. 18 pp.

Olsen. B. 1992. Teljingar av lomviga í Høvdanum á Skúvoynni 1973 til 1991. Fiskirannsóknir 7: 6-15. (Faroese).

Olsen, B. \& M. Permin 1974. The population of Gannet Sula bassana on Mykinesholmur, 1972. Dansk orn. Foren. Tidsskr. 68: 39-42. (Danish, Engl. summ.).

\section{Greenland}

Boertmann, D. 1994. An annotated checklist to the birds of Greenland. Meddr. Grønland Biosc. 38: 64 pp. Boertmann, D. 1996. Environmental impacts of shipping to and from Citronen Fjord. A preliminary assessment. NERI Technical Report 162: 35 pp. 
Boertmann, D. 2001. The Iceland Gull complex in Greenland. British Birds 94: 546-548.

Boertmann, D. 2004. Seabird colonies and moulting Harlequin Ducks in South Greenland. Research Notes from NERI, No. 191, 33 pp.

Boertmann, D. \& A. Mosbech 1997. Breeding distribution and abundance of the Great Cormorant Phalacrocorax carbo carbo in Greenland. Polar Research 16: 93-100.

Boertmann, D. \& A. Mosbech 1998. Distribution of Little Auk (Alle alle) breeding colonies in Thule District, northwest Greenland. Polar Biology 19: 206-210.

Boertmann, D., A. Mosbech, K. Falk \& K. Kampp 1996. Seabird colonies in western Greenland. NERI Technical Report 170, 148 pp.

Christensen, K.D. \& K. Falk 2001. Status of the Common Eider breeding in the municipality of Avanersuaq (Thule), north-west Greenland. Polar Research 20: 109-114.

Egevang, C. \& D. Boertmann 2003. Havternen i Grønland. Danmarks Miljøundersøgelser, Faglig Rapport nr. 438, 69 pp.

Egevang, C., D. Boertmann, A. Mosbech \& M.P. Tamstorf 2003. Estimating colony area and population size of Little Auks Alle alle, at Northumberland Island using aerial images. Polar Biology 26: 8-13.

Evans, P.G.H. \& K. Kampp 1991. Recent changes in Thick-billed Murre populations in West Greenland. Pp. 714 in: A.J. Gaston \& R.D. Elliot (eds). Studies of high-latitude seabirds. 2. Conservation biology of Thick-billed Murres in the Northwest Atlantic. Can. Wildl. Ser., Occ. Paper No. 69.

Falk, K. \& K. Kampp 1997. A manual for monitoring Thick-billed Murre populations in Greenland. - Pinngortitaleriffik, Grønlands Naturinstitut, Teknisk Rapport 7.

Falk, K. \& K. Kampp 1998. Langsigtet moniteringsplan for lomvier i Grønland. Pinngortitaleriffik, Grønlands Naturinstitut, Teknisk Rapport 18.

Falk, K. \& K. Kampp 2001. Lomvie i Grønland: mulige effekter af forskellige bestandspåvirkende faktorer, og praktiske grænser for ressourceudnyt- telse. Pinngortitaleriffik, Grønlands Naturinstitut, Teknisk Rapport 38.

Falk, K., C. Hjort, K.D. Andreasen, M. Christensen, M. Elander, K. Ericson, K. Kampp, R.M. Kristensen, N. Møbjerg, S. Møller \& J.M. Weslawski 1997. Seabirds utilizing the Northeast Water polynya. Journal of Marine Systems 10: 47-65.

Forchhammer, M. \& L. Maagaard 1990. Distribution of breeding Sabine's Gulls in Greenland. Dansk Orn. Foren. Tidsskr. 84: 162-164.

Frich, A.S. 1997. Fuglelivet og dets udnyttelse på Grønne Ejland i Vestgrønland, juni 1996. Pages 19. Pinngortitaleriffik, Greenland Institute of Natural Resources, Nuuk, Greenland.

Gilg, O., B. Sabard, B. Sittler, F. Mariaux, P. Leguesdron \& V. Gilg 2004. Ecopolaris 2003. Ecological expedition to North Greenland \& Dove Bugt: North-East Greenland National Park. Field report, Groupe de Recherches en Ecologie Arctique.

Kampp, K. 1990. The Thick-billed Murre population of the Thule district, Greenland. Arctic 43: 115-120.

Kampp, K. \& K. Falk 1994. The birds of Ydre Kitsissut (Kitsissut Avalliit), Southwest Greenland. Meddr Grønland. Bioscience 42: 25 pp.

Kampp, K., H. Meltofte \& C.E. Mortensen 1986. Little Auks in Scoresby Sund. Zoological Museum and Greenland Environmental Research Institute, Copenhagen: 60 pp. (Danish, Engl. summ.).

Kampp, K., H. Meltofte \& C.E. Mortensen 1987. Population size of the Little Auk Alle alle in East Greenland. Dansk Orn. Foren. Tidsskr. 81: 129-136.

Kampp, K., D.N. Nettleship \& P.G.H. Evans 1994. Thick-billed Murres of Greenland: status and prospects. Pp. 133-154 in: D.N. Nettleship, J. Burger \& M. Gochfeld (eds). Seabirds on Islands, Threats, case-studies and action plans. BirdLife International, Conservation series No. 1.

Merkel, F.R. 2002. Ederfugleoptællinger i Ilulissat, Ummannaq og Upernavik Kommuner, 1998-2001. Pinngortitaleriffik, Grønlands Naturinstitut, Teknisk Rapport nr. 43.

Merkel, F.R. \& S.S. Nielsen 2002. Langsigtet overvågningsprogram for 
ederfuglen i Ilulissat, Uummannaq og Upernavik Kommuner, vejledning og baggrund. Pinngortitaleriffik, Grønlands Naturinstitut, Teknisk Rapport 44.

Nettleship, D.N. \& P.G.H. Evans 1985. Distribution and status of the Atlantic Alcidae. Pp. 53-154 in: D.N. Nettleship \& T.R. Birkhead (eds). The Atlantic Alcidae. Academic Press, London, 573 pp.

Nyeland, J. 2004. Apparent trends in the Black-legged Kittiwake in Greenland. Waterbirds 27: 342-349.

\section{Iceland}

Asbirk, S., L. Berg, G. Hardeng, P. Koskimies \& A. Petersen 1997. Population sizes and recent trends in the Nordic countries 1978-1994. TemaNord 1997:614. Nordisk Ministerråd. 88 pp.

Gardarsson, A. 1979. [A census of breeding Cormorants (Phalacrocorax carbo) and Shags (Phalacrocorax aristotelis) in Iceland in 1975.] Natturufraedingurinn 49(2-3) 126-154. (Icel., Engl. summ.).

Gardarsson, A. 1995. [Numbers and distribution of Common Murre Uria aalge, Thick-billed Murre $U$. lomvia and Razorbill Alca torda in Iceland.] Bliki 16: 47-65. (Icel., Engl. summ.).

Gardarsson, A. 1996. [Numbers and distribution of breeding Kittiwake Rissa tridactyla in Iceland.] Bliki 17: 1-16. (Icel., Engl. summ.).

Gardarsson, A. 2005. [Numbers of Northern Gannet Morus bassanus in Iceland 1999.] Bliki 26: 17-20 (Icel., Engl. summ.).

Ingólfsson, A. 2005. [Environmental studies in Gilsfjordur. Third research period: The condition of the environment and biota 5-6 years after building the causeway across the fjord.] Liffraedistofnun haskolans. Fjolrit no. 74. 85 p. (Icel.).

Lund-Hansen, L.C. \& P. Lange 1991. The numbers and distribution of the Great Skua Stercorarius skua breeding in Iceland 1984-1985. Acta Naturalia Islandica 34. 16 pp.

Petersen, A. 1998. [Icelandic Birds.] Vaka-Helgafell, Reykjavik. 312 pp. (Icel.)
Petersen, A. 2000. [Monitoring of Icelandic seabirds.] Natturufraedingurinn 69(3-4): 189-200. (Icel., Engl. summ.).

Petersen, A. 2001. [The Common Eider in Iceland. (Status of research and international on the conservation of eiders).] Náttúrufræðistofnun Íslands NÍ-01025. 29 p

Petersen, A. 2002. Circumpolar Murre Conservation Strategy - Implementation Plan 2004-2008 - Iceland. Náttúrufræðistofnun Íslands NÍ03006. $36 \mathrm{p}$.

Petersen, A. 2003. Icelandic Programs related to the Circumpolar Biodiversity Monitoring Program.

Náttúrufræðistofnun Íslands. NÍ03003. 19 p.

Petersen, A. 2001. [The Common Eider in Iceland. (Status of research and international on the conservation of eiders).] Náttúrufræðistofnun Íslands NÍ-01025. 29 p. (Icel.).

Petersen, A. in prep. [Monitoring of the Icelandic Black Guillemot population.] Náttúrufræðistofnun Íslands. In press. (Icel., Engl. summ.).

Petersen, A. \& S. Thorstensen 1993. [The distribution and numbers of Black-headed Gulls in Eyjafjörður (N-Iceland) 1990.] Bliki 13: 45-59 (Icel., Engl. summ.).

Petersen, A. \& S. Thorstensen 2004. [Monitoring and population changes of Common Gulls Larus canus in Eyjafjörður (N-Iceland) 1980-2000.] Náttúrufraedingurinn 72 (3-4): 144154 (Icel., Engl. summ.).

Petersen, A. \& S. Thorstensen 2005. [Monitoring of Black-headed Gulls Larus ridibundus in Eyjafjörður (NIceland) 1995 and 2000.] Náttúrufraedingurinn 73(1-2): 39-46 (Icel., Engl. summ.).

\section{Jan Mayen and Svalbard}

Anker-Nilssen, T., V. Bakken, H. Strøm, A. Golovkin, V. Bianki \& I. Tarinkova 2000. The Status of marine birds breeding in the Barents Sea Region. Norsk Polarinstitutt Rapportserie. Rapport no. 113A. 213 p.

Anker-Nilssen, T., J.O. Bustnes, K.E. Erikstad, P. Fauchald, S.-H. Lorentsen, T. Tveraa, H. Strøm \& R.T. Bar- 
rett 2005. SEAPOP. Et sjøfuglprogram for styrket beslutningsstøtte i marine områder. - NINA Rapport 1. $66 \mathrm{pp}$.

Bakken, V. (ed.) 2000. Seabird Colony Databases of the Barents Sea Region and the Kara Sea. Norwegian Polar Institute Report Series no. 115. 78 p.

Barrett, R.T., T. Anker-Nilssen, K.E. Erikstad, S.-H. Lorentsen \& H. Strøm 2004. Initiating SEAPOP in the Lofoten and Barents Sea area? Report from the OLF study in 2004. NINA Minirapport 86, Norwegian Institute for Nature Research, Trondheim, 11 pp.

Franeker J.A. van, C.J. Camphuysen \& F. Mehlum 1998. The birds of Jan Mayen. Circumpolar Journal 13: 2843.

Gabrielsen, G.W., B. Brekke, I.G. Alsos \& J.R. Hansen 1997. Natur- og kulturmiljøet på Jan Mayen. Norsk Polarinstitutt Meddelelser no. 144.

Gabrielsen, G.W. \& H. Strøm 2004. Seabird Research and Monitoring on Jan Mayen. Pp. 181-194 in: S. Skreslet (ed.). Jan Mayen Island in Scientific Focus. Kluywer Academic Publ. Netherlands.

Hisdal, V. 1998. Svalbard nature and history. Nor. Polarinst. Polarhåndbok 12. Oslo. Norwegian Polar Institute. $123 \mathrm{pp}$.

Isaksen, K., V. Bakken \& Ø. Wiig 1998. Potential effects on seabirds and marine mammals of petroleum activity in the northern Barents Sea. Norsk Polarinst. Medd. no. 154, 41pp+Appendix.

Mehlum, F. \& P.E. Fjeld 1987. Catalogue of seabird colonies in Svalbard. Norsk Polarinst. Rapp. Serie nr. 35, 222 pp.

Mehlum, F. \& V. Bakken 1994. Seabirds in Svalbard (Norway): status, recent changes and management. Pp. 155-171 in: D.N. Nettleship, J. Burger \& M. Gochfeld (eds). Seabirds on islands: threats, case studies and action plans. BirdLife Conservation Series No. 1.

Moe, K.A., T. Anker-Nilssen, V. Bakken, O.W. Brude, P. Fossum, S.H. Lorentsen \& G.M. Skeie 1999. Particularly sensitive areas (PSA) and petroleum activity. Implementation of criterias and identification of PSA in
Norwegian waters with focus on acute oil pollution. Alpha Environmental Consultants-Inst. of Mar. Res.-Norw. inst. of nature res.-Norw. Polar Inst. Alpha Report 1007-1 (51 pp.) + WebAtlas CD-ROM. (Norwegian, Engl. summ.).

Strøm, H. in press. Birds in Svalbard. Pp. 86-191 in: K.M. Kovacs (ed.). Birds and Mammals of Svalbard. Polarhåndbok no. 13, Norwegian Polar Institute. 203 pp.

Strøm, H. \& G. Bangjord 2004. Birds and mammals of Svalbard in: P. Prestrud, H. Strøm \& H. Goldman. A catalogue of the terrestiral and marine animals of Svalbard. Norw. Pol. Inst. Skrifter no. 201

Systad, G.H., V. Bakken, H. Strøm \& T. Anker-Nilssen 2003. Særlig Verdifulle Områder (SVO) for sjøfugl i området Lofoten-Barentshavet - implementering av kriterier for identifikasjon av SVO i den norske delen av Barentshavsregionen. NINA-notat 2003.

Theisen, F. \& O.W. Brude 1998. [Evaluation of the protected areas in Svalbard.] Norsk Polarinst. Medd. nr. 153, 144 pp+Appendix. (Norwegian).

\section{The use of seabird colony databases}

Anker-Nilssen, T., K.E. Erikstad \& S.H. Lorentsen 1996. Aims and effort in seabird monitoring: an assessment based on Norwegian data. Wildlife Biology 2: 17-26.

Boertmann, D., A. Mosbech, K. Falk \& K. Kampp 1996. Seabird colonies in western Greenland. NERI Technical Report 170: 148 pp

Furness, R.W. \& K. Camphuysen 1997. Seabirds as monitors of the marine environment. ICES Journal of Marine Science 54: 726-737.

Mehlum, F. \& G.W. Gabrielsen 1995. Energy expenditure and food consumption by seabirds populations in the Barents Sea region. Pp. 457-470 in: H.R. Skjoldal, C. Hopkins, K.E. Erikstad \& H.P. Leinaas (eds). Ecology of Fjords and Coastal Waters. Elsevier Science B.V.

Montevecchi, W.A. \& R.A. Myers 1997. Centurial and decadal ocea- 
nographic influences on changes in northern gannet populations and diets in the north-west Atlantic: implications for climate change. ICES Journal of Marine Science 54: 608-614.

Monaghan, P. 1996. Relevance of the behaviour of seabirds to the conservation of marine environments. Oikos 77: 227-237.

Mosbech, A., K.L. Anthonsen, A. Blyth, D. Boertmann, E. Buch, D. Cake, L. Grøndahl, K.Q. Hansen, H. Kapel, S. Nielsen, N. Nielsen, F. von Platen, S. Potter \& M. Rasch 2000. Environmental Oil Spill Sensitivity Atlas for the West Greenland Coastal Zone. Ministry of Environment and Energy, The Danish Energy Agency. Mosbech, A., D. Boertmann, B.Ø. Olsen, S. Olsvig, F. von Platen, E. Buch, K.Q. Hansen, M. Rasch, N. Nielsen, H.S. Møller, S. Potter, C. Andreasen, J. Berglund \& M. Myrup 2004a. Environmental Oil Spill Sensitivity Atlas for the South Greenland Coastal Zone. National Environmen- tal Research Institute and Geological Survey of Denmark and Greenland, Ministry of Environment.

Mosbech, A., D. Boertmann, B.Ø. Olsen, S. Olsvig, F. von Platen, E. Buch, K.Q. Hansen, M. Rasch, N. Nielsen, H.S. Møller, S. Potter, C. Andreasen, J. Berglund \& M. Myrup 2004b. Environmental Oil Spill Sensitivity Atlas for the West Greenland Coastal Zone $68^{\circ}-72^{\circ} \mathrm{N}$. National Environmental Research Institute and Geological Survey of Denmark and Greenland, Ministry of Environment. Nettleship, D. 1997. Long-term monitoring of Canada's seabird populations. Pp. 16-23 in: E.H. Dunn, M.D. Cadman \& J.B. Falls (eds). Monitoring bird populations: The Canadian experience. Canadian Wildlife Service, Occasional Paper No. 95.

Thompson, P.M. \& J.C. Ollason 2001. Lagged effects of ocean climate changes on fulmar population dynamics. Nature 413: 417-420. 

Appendix - User’s Manual 



\section{Colony}

A Database Programme for Seabird Colonies

\section{User’s Manual}

Programme developed by

Harvey Goodwin and Vidar Bakken

Norwegian Polar Institute

Telephone: +47 77750568

Email: harvey@npolar.no

Manual written by

Harvey Goodwin and Vidar Bakken 


\section{Contents}

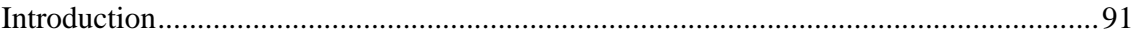

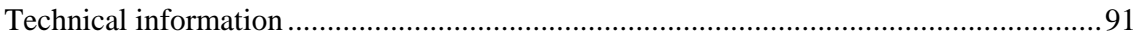

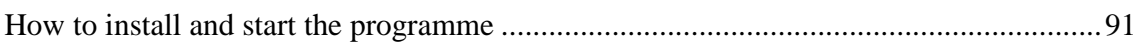

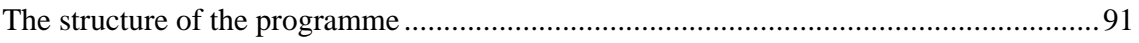

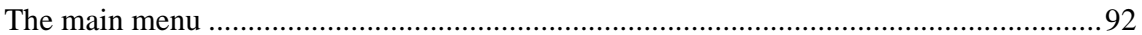


Introduction

COLONY is a database programme that was originally designed for the accumulation and processing of data on seabird colonies in the Barents Sea. The geographic scope of the database now comprises Svalbard, the Russian part of the Barents Sea, Jan Maeyn, Iceland, Greenland and the Faroes. The database allows easy storage and overview of information about the location of seabird colonies, their breeding species and the number of breeding pairs in various years. Maintenance of the database requires that all registrations for the seabird colonies be completed and updated after each breeding season. The updated database should provide a powerful management tool in detecting large scale trends in the breeding populations of the species studied.

COLONY.MDB can easily be applied to other sea areas and seabird species.

\section{Technical information}

The programme is written in Clipper MS Access. The programme can be run on any PC with a Windows operating system.

The programme works directly on the data files on the disk. Therefore, there is no opening and saving of files - the changes you make in the programme are saved immediately in the database.

\section{How to install and start the programme}

You should copy the file "Colony.mdb" to your hard disk. Double click on the file to open the database.

\section{The structure of the programme}

The programme is Windows-based. The information is built up around the colony description such that all associated information and survey data is accessed from the same window. A short description of the selected option is given below or next to the option.

The programme is built up on a number of related tables, see the first figure below (the detailed setup of the tables are described later). The programme connects these tables so that you can easily look at all information available for one colony. 


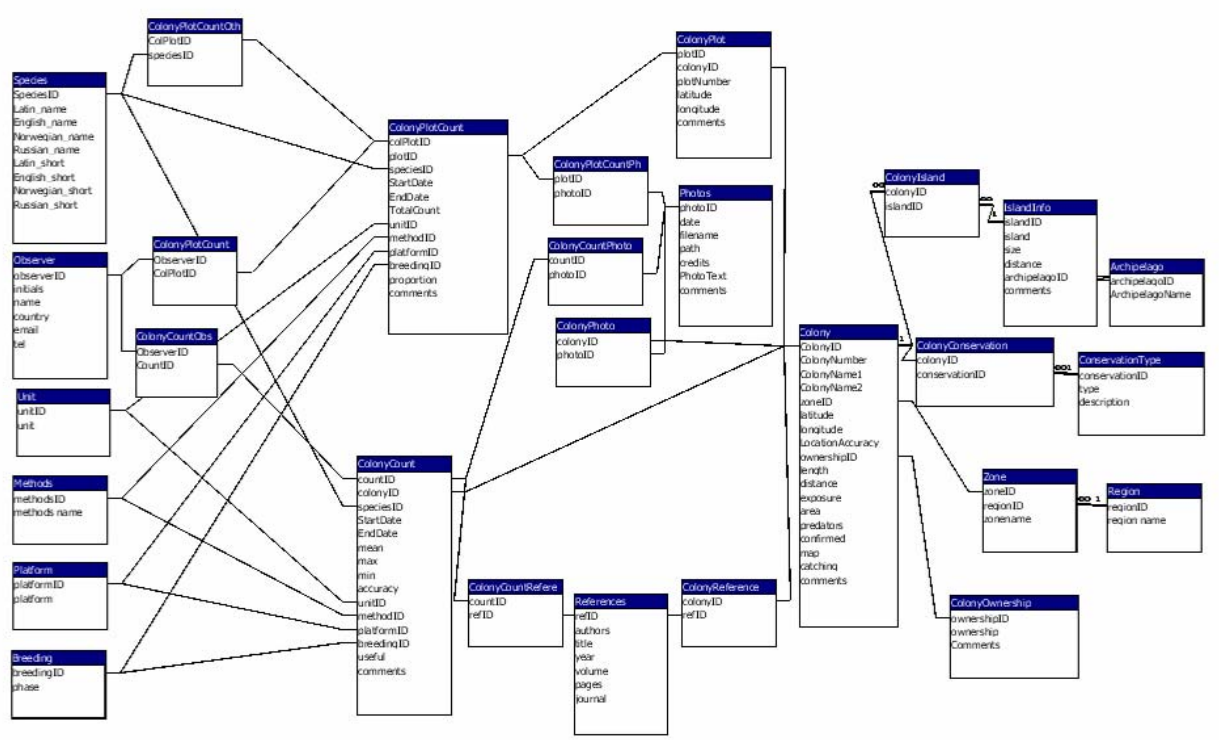

The main menu

After you have started the programme the main menu opens. A short description of each option in the main menu is given here - for several options more thorough description will be given later.

\section{Data Input}

This is the standard input page for most users wishing to enter colony data and survey data. Colony Description takes you further to the input frames for all data related to colonies. Under Reference Data are Lookup-tables (LUTs) for adding new references, photographs and observers that you require in colony description.

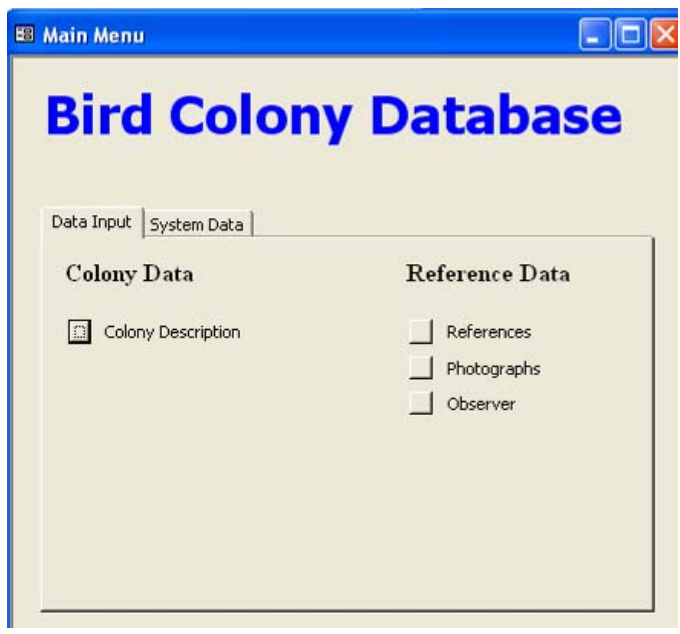




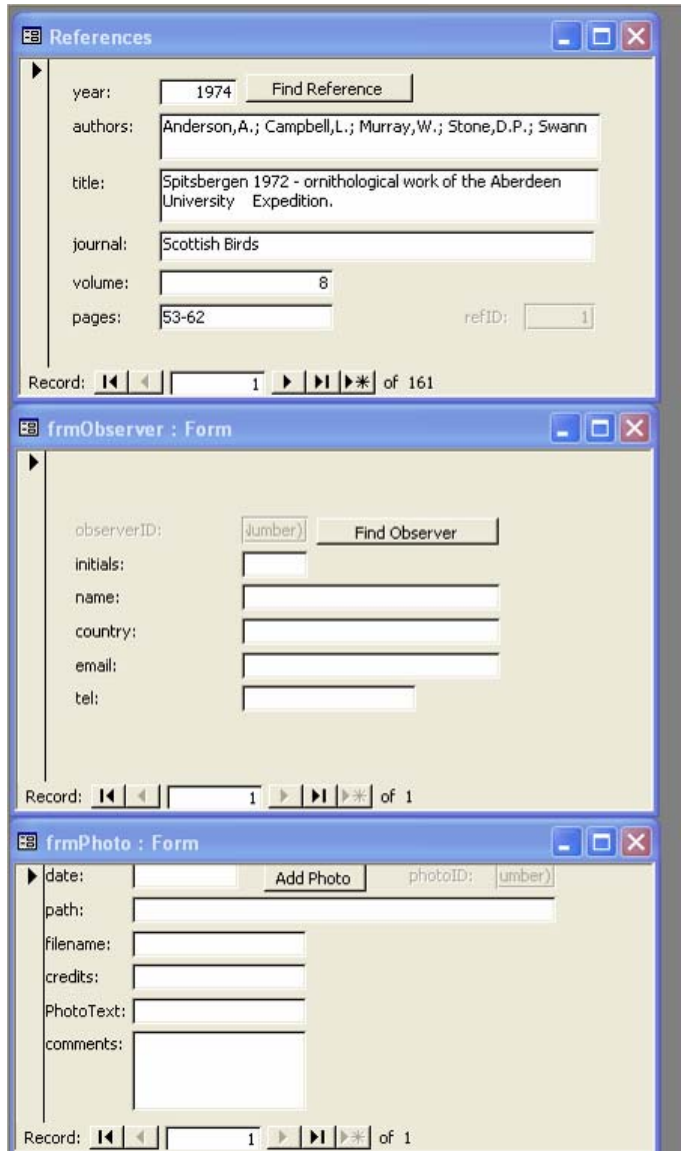

\section{System Data}

This group of input forms is for administrator level and is for adding new values to LUTs and should have access restricted to the administrator. Input in these LUTs is done basically directly in the table in question.

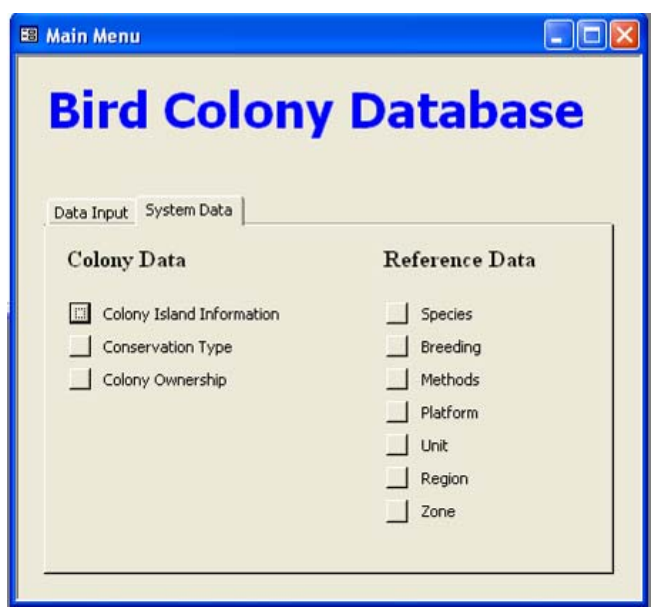




\section{Colony Description}

This is the main input form for the database and is divided up in 4 pages: Colony Description, Additional Colony Data, Count Data, and Study Plot Data to allow for easily relating data to each colony. Simply fill out all relevant information for the colony and click on one of the tabs to flick to the next page. Remember that you are editing directly in the database and all changes made in this form will be automatically saved. To jump directly to an existing record click on "Find". Clicking on the bar on the left-hand side of the form saves any changes immediately as does moving to a new record. To disregard changes before moving to a new record or clicking the bar press "Esc".

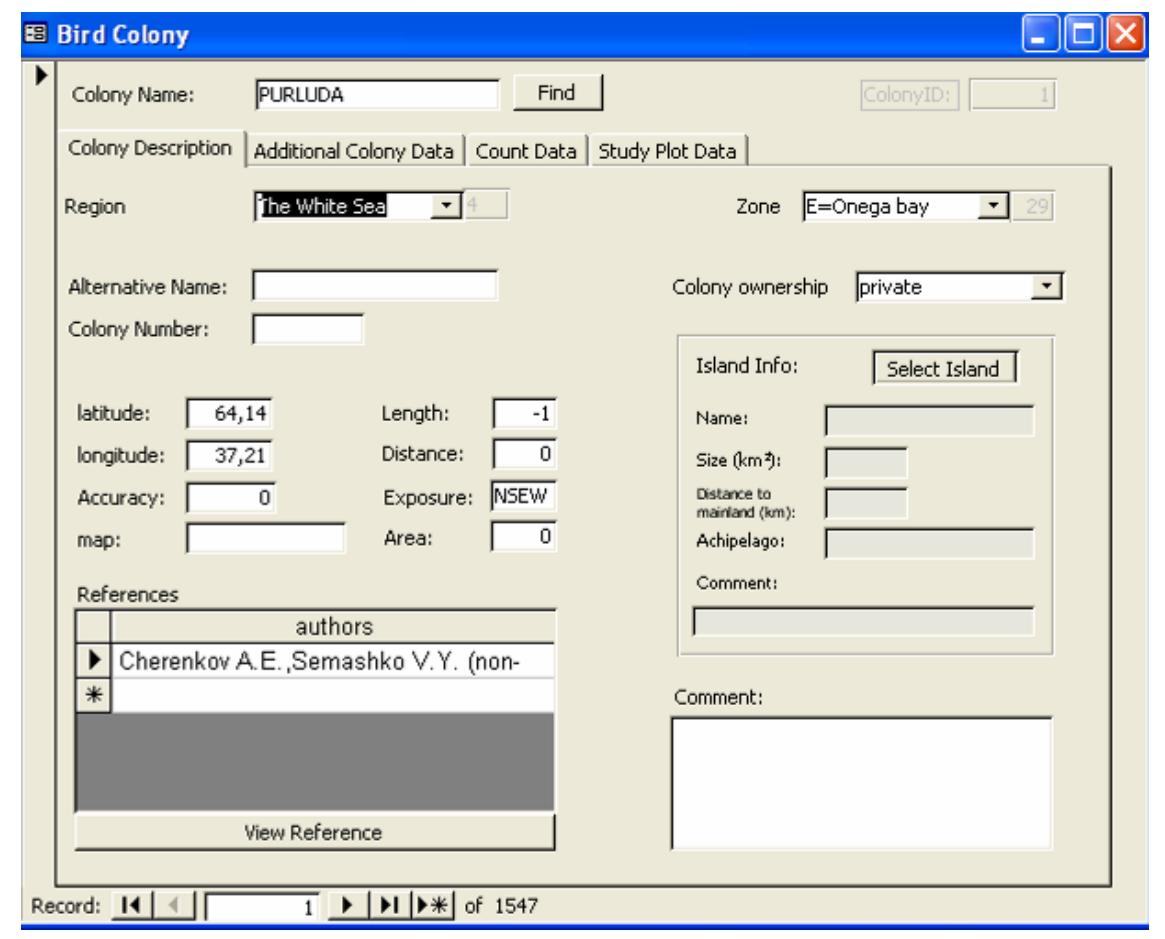

This figure shows the main entry data for describing a colony. By clicking on the arrows at the bottom of the form you can navigate through the database and view other records. Clicking the arrow with a star starts a new blank record so that you can enter details about a new colony. 


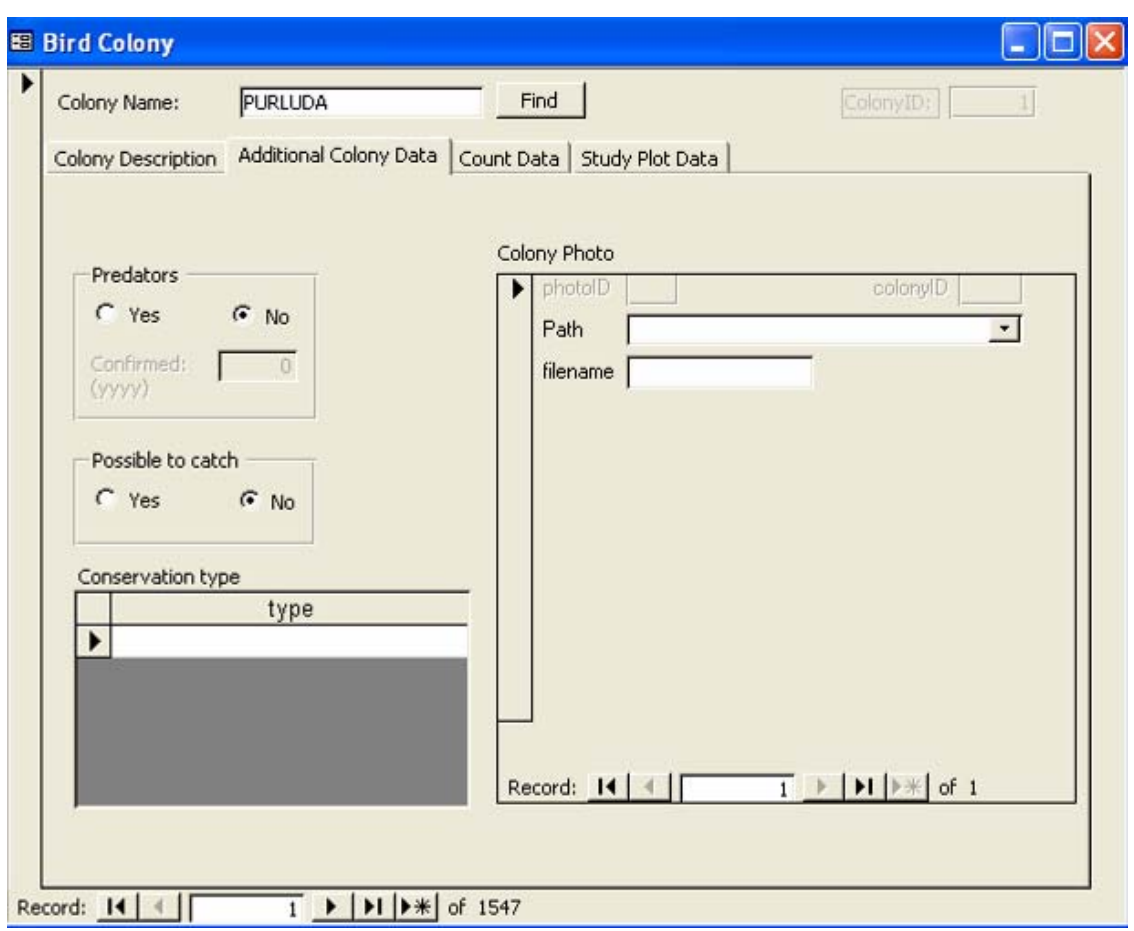

This figure is the form for additional information about the colony including photographs about the site.

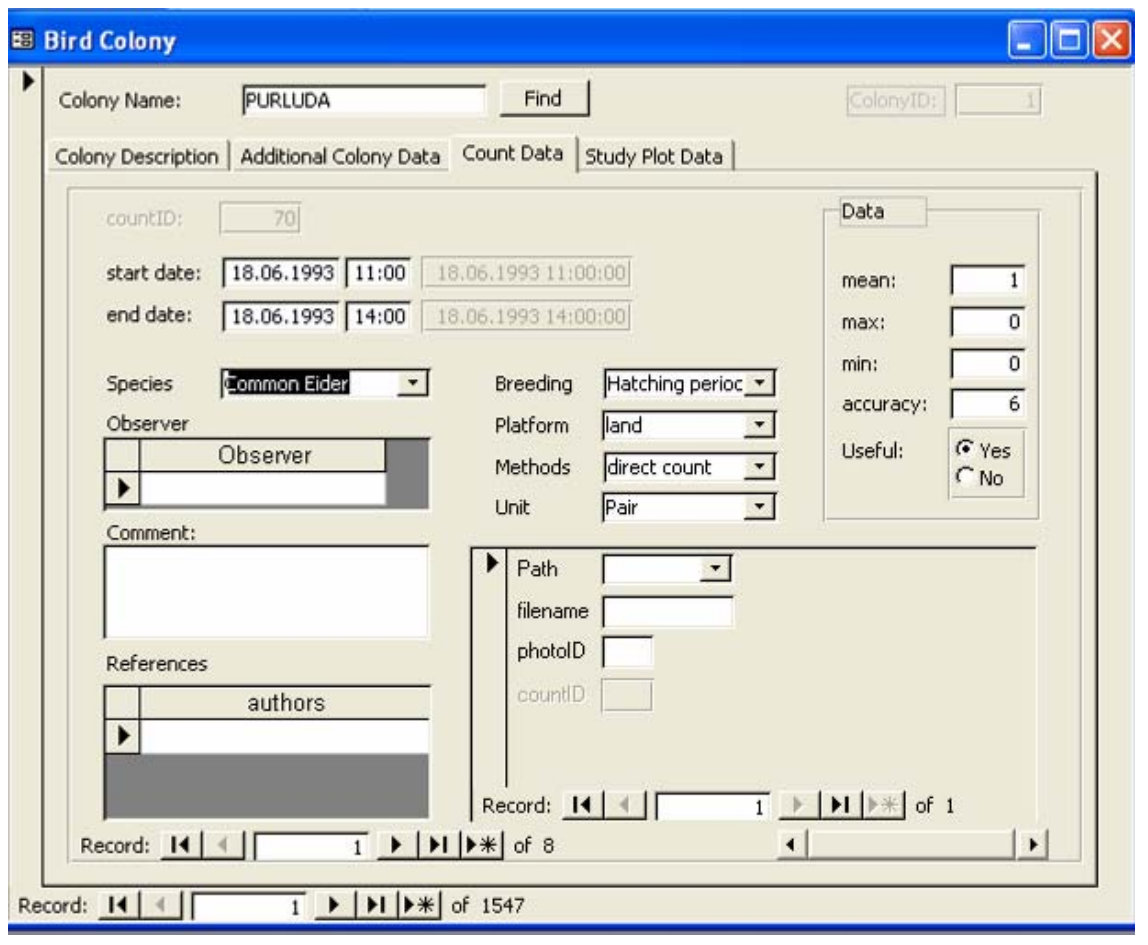

This page is for inputting the actual count data. Many of the options are predefined and you must select an item from the dropdown lists. If you cannot find the value you need contact your database administrator or 
update the appropriate LUT accessible from the main menu. Both Observer and Authors can contain several entries. Navigation between count data for this colony is achieved by clicking the "embedded" arrows or those showing 1 of 8 in this example. As many photos as necessary can be added to the database. Clicking the arrow with a star allows you to enter new data.

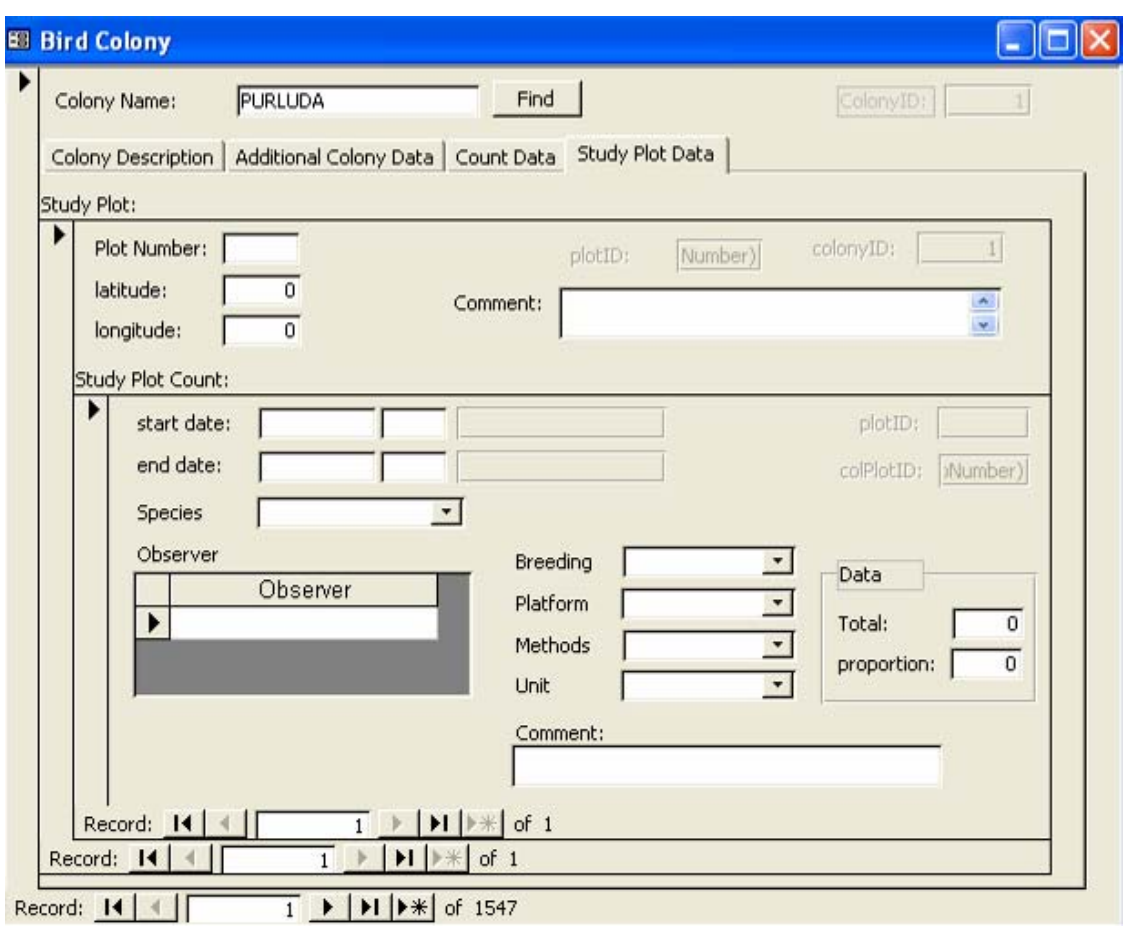

This page is for entering study plot data and functions very similarly to the page for count data. However here is an extra level where within each colony one or more plots can be registered, and under each plot many study plot surveys can be recorded.

Delete

To delete a record click the selector bar on the left hand side of the form to select the record and then hit the delete key. Be sure that you know what you are doing before selecting this option. WARNING!!! Deleting a colony description will also delete species counts, counts in study plots and photo documentation records for this colony. Deletions can not later be recalled. You can of course select individual counts or study plot counts by clicking the appropriate embedded selector bar in the frame and then the delete key.

Quit

Close the Colony.mdb file. 